UNIVERSIDADE DE SÃO PAULO

INSTITUTO DE GEOCIÊNCIAS

\title{
GEOCRONOLOGIA DE EVENTOS MAGMÁTICOS E MINERALIZAÇÕES ASSOCIADAS NO PRECAMBRIANO DA FAIXA SERIDÓ, PROVÍNCIA BORBOREMA
}

Maria Helena Bezerra Maia de Hollanda

Tese apresentada ao Concurso de LivreDocência junto ao Departamento de Mineralogia e Geotectônica do Instituto de Geociências da Universidade de São Paulo, na Área de Conhecimento de Geologia Isotópica.

São Paulo 


\section{GEOCRONOLOGIA DE EVENTOS MAGMÁTICOS E MINERALIZAÇÕES ASSOCIADAS NO PRECAMBRIANO DA FAIXA SERIDÓ, PROVÍNCIA BORBOREMA}

Maria Helena Bezerra Maia de Hollanda

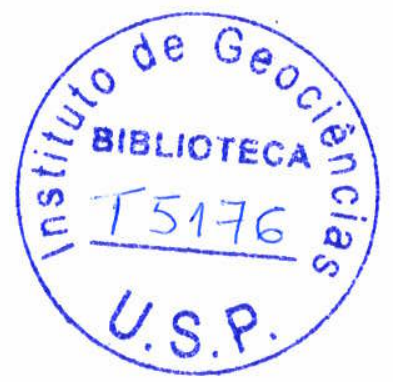

Tese apresentada ao Concurso de LivreDocência junto ao Departamento de Mineralogia e Geotectônica do Instituto de Geociências da Universidade de São Paulo, na Área de Conhecimento de Geologia Isotópica.

DEDALUS - Acervo - IGC

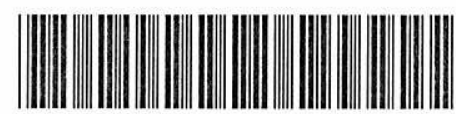

30900030874

São Paulo 
A vocês, que nos deram a vida e nos ensinaram a vivê-la com dignidade... não bastaria um obrigado.

A vocês, que iluminaram nossos caminhos com afeto e dedicação para que os trilhássemos sem medo e cheios de esperanças... não bastaria um muito obrigado.

$A$ vocês, que se doaram inteiros e renunciaram aos seus sonhos para que, muitas vezes, pudéssemos realizar os nossos... não bastaria um muitíssimo obrigado.

A vocês, pais por natureza, opção e amor, não bastaria dizer o quanto é difícil escolher palavras para agradecer tudo isso... mesmo quando procuramos uma forma verbal ou escrita de exprimir a emoção impar em dizer simplesmente OBRIGADO.

(modificado de um autor desconhecido)

A meus valorosos pais, Daniel (in memorian) e Victória Hollanda. 


\section{AGRADECIMENTOS}

A obtenção do conjunto de dados aqui apresentados só foi possível mediante o valioso auspício financeiro de agências de fomento, em especial da FAPESP e CNPq, e de parcerias com laboratórios nacionais (CPGeo) e internacionais, estes últimos através de seus pesquisadores - Dr. Liu Dunyi (Beijing SHRIMP Center, China), Dr. Richard Armstrong (Research School of Earth Sciences, ANU, Australia) e Dra. Holly Stein (AIRIE Program, Colorado State University, USA). Essas parcerias refletiram-se na obtenção de análises U$\mathrm{Pb}$ SHRIMP em zircão, obtidas na Austrália em 2001 e na China entre 2004-2010, bem como Re-Os em molibdenita, realizadas em 2011 nos EUA.

Tão importante quanto os colegas acima mencionados caberia aqui incluir outros tantos nomes de pessoas que estiveram presentes ao longo dos vários anos que representam o tempo de dedicação a essa jornada. Todavia, lembrar não é uma tarefa fácil, o que me faz estender os agradecimentos da maneira mais ampla possível a todos os colegas professores, alunos bolsistas, técnicos de laboratório ou funcionários administrativos que me apoiaram durante a realização dessa árdua empreitada. Em especial a Carlos J. Archanjo (USP), Laécio C. Souza (UFRN) e João Adauto de S. Neto (UFPE) que participaram diretamente do planejamento e execução dos três projetos que nortearam a elaboração da presente tese.

Por fim, não poderia deixar de agradecer à minha família pelo incentivo permanente, e em especial ao meu marido ("Docinho") e queridos filhos, Daniel e Laura - por serem a alegria, a força e o estímulo do meu dia-a-dia. 
"É inevitável que, quanto mais ambicioso seja o trabalho mais imperfeita seja a sua execução...mas isso não implica que ele deva ser divulgado somente quando não houver mais esperança de melhorá-lo. " 
Essa tese apresenta e discute um conjunto de novos dados geocronológicos $\mathrm{U}-\mathrm{Pb}$ SHRIMP em zircão de ortognaisses do embasamento (Complexo Caicó) da Faixa Seridó, bem como para granitos intrusivos na sua cobertura metasedimentar (Grupo Seridó; Província Borborema, NE do Brasil). Os resultados aqui obtidos, combinados com outros dados geocronológicos disponíveis na literatura, mostram que a atividade magmática da faixa distribuiu-se em um amplo intervalo de tempo, com maior expressividade no Paleoproterozoico $(2,4$ a $2,2 \mathrm{Ga})$ e no Neoproterozoico $(0,6$ a $0,52 \mathrm{Ga})$. Um expressivo magmatismo, representado por orto(augen)gnaisses (suíte $G_{2}$ ), foi concentrado no Riaciano para definir um período relevante de acresção e retrabalhamento crustal. Por sua vez, o magmatismo Neoproterozoico extendeu-se por cerca de cem milhões de anos, com registro inicial em c. 595 Ma relacionado a intrusão de plútons de composição diorítica a granítica, e alcançando maior importância em c. $575 \mathrm{Ma} \mathrm{com} \mathrm{a} \mathrm{migmatização} \mathrm{do} \mathrm{embasamento}$ paleoproterozoico, colocação de granitos (suíte $G_{3}$ ) e metamorfismo de alta temperatura e baixa pressão. A atividade ígnea prosseguiu até o Cambriano definida pela colocação de leucogranitos entre 545 e $525 \mathrm{Ma}$ e pegmatitos em 515 - $510 \mathrm{Ma}$. As mineralizações da Faixa Seridó possuem uma estreita correlação temporal com a recorrência do magmatismo tardio como indicam dados inéditos Re-Os em skarns contendo W-Mo. Esses resultados, combinados com a idade de pegmatitos contendo Be-Nb-Ta, mostram que os depósitos mineralizados do Seridó foram formados na transição Neoproterozoico-Cambriano. 
This thesis presents and discusses a set of new U-Pb SHRIMP geochronological data in zircon in the orthogneiss of the basement complex of the Serido Belt (Borborema Province, NE Brazil), as well granites and its metasedimentary cover (Seridó Group). The results obtained together with other geochronological data in literature, show that the magmatic activity in this belt occurred within a large time range, with peaks at the Paleoproterozoic $(2.4$ a $2.2 \mathrm{Ga})$ and the Neoproterozoic $(0.6$ a $0.52 \mathrm{Ga})$. In the Paleoproterozoic, the magmatism represented by ortho(augen)gneisses ( $G_{2}$ suite) was concentrated in the Rhyacian defining an important period of crustal accretion and reworking. On the other hand the Neoproterozoic magmatism extended for about a hundred million years, initiated at c. $595 \mathrm{Ma}$ as corroborated by diorite and granite intrusions, and attaining its peak at c. $575 \mathrm{Ma}$ when the migmatization of the Paleoproterozoic basement, emplacement of the granites $\left(G_{3}\right.$ suite) and high-grade metamorphism occurred. The igneous activity continued until the Cambrian time defined by leucogranites between 545 and $525 \mathrm{Ma}$ and pegmatites from 515 - $510 \mathrm{Ma}$. Re-Os data for the W-Mo in skarns of the Seridó scheelitiferous province indicate a narrow temporal correlation of these deposits with the Late Brasilian magmatism. When combined with $\mathrm{Be}$-( $\mathrm{Nb}-\mathrm{Ta})$-bearing pegmatite ages, the results show that all hydrothermal deposits in Seridó belt were generated during the Neoproterozoic-Cambrian transition. 


\section{LISTA DE FIGURAS}

\section{CAPÍTULO 2}

Figure 1. Pre-drift reconstruction for the main geological features of the Borborema Province (NE Brazil) and the shields of Nigeria and Cameroon in Africa.

Figure 2. Simplified geological map of the Seridó-Jaguaribe domain showing the locations of the studied augen gneiss plutons.

Figure 3. Geological map of the Santa Luzia region (Paraiba State) and a schematic cross-section.

Figure 4. Field aspects of the augen gneisses in Seridó region.

Figure 5. U-Pb concordia diagram for the banded orthogneiss of the Santa Luzia region.

Figure 6. U-Pb concordia diagram for the Riacho Fundo metaleucogabbro.

Figure 7. U-Pb concordia diagram for the São Rafael augen gneiss.

Figure 8. U-Pb concordia diagram for the São José do Seridó augen gneiss.

Figure 9. U-Pb concordia diagram for the Santana do Matos augen and leucogneiss.

Figure 10. U-Pb concordia diagram for the Antonio Martins augen gneiss.

Figure 11. U-Pb concordia diagram for the Serra Negra augen gneiss.

Figure 12. Time-related $\mathrm{Nd}$ evolution diagram for the augen and leucogneisses.

\section{CAPÍTULO 3}

Figure 1. Pre-Mesozoic fit between the northern Borborema Province (NE Brazil) and southern Nigerian shield (Africa) highlighting the schist belts and main vertical shear zones.

Figure 2. Simplified geological map of the Seridó-Jaguaribe domain.

Figure 3. Geological map of the central domain of the Seridó belt.

Figure 4. U-Pb concordia diagrams for rocks of the Totoró pluton.

Figure 5. U-Pb concordia diagrams for rocks of the Acari pluton.

Figure 6. Field aspects of the Santa Luzia migmatite.

Figure 7. Simplified geological map of the Santa Luzia migmatite and distribution of AMS sites.

Figure 8 . Isothermal remanent magnetisation acquisition and respective susceptibility (k) for the Santa Luzia migmatite.

Figure 9. Magnetic fabric (foliation, lineation) of the migmatitic dome.

Figure 10. Cathodoluminescence image of selected zircons from the Santa Luzia migmatite.

Figure 11. U-Pb concordia diagram for a granitic nebulite of the Santa Luzia dome.

Figure 12. Schematic block-diagram illustrating the relationship between the fabric of the magmatic rocks and the structure of the central domain of the Seridó belt.

\section{CAPÍTULO 4}

Figura 1. Mapa geológico simplificado da região central da Faixa Seridó destacando as unidades litoestratigráficas neoproterozoicas e os principais depósitos de W-Mo.

Figura 2. Diagramas isocrônicos $\mathrm{Sm}-\mathrm{Nd}$ incluindo os minerais calciossilicatados da paragênese de alta temperatura da mina Brejuí.

Figura 3. Diagramas isocrônicos $\mathrm{Sm}-\mathrm{Nd}$ incluindo os minerais calciossilicatados da paragênese de baixa temperatura da mina Brejuí.

Figura 4. Diagrama isocrônico $\mathrm{Sm}-\mathrm{Nd}$ incluindo anfibólio e piroxênio da paragênese de alta temperatura da mina Bonfim.

Figura 5. Diagramas isocrônicos ${ }^{206} \mathrm{~Pb} /{ }^{204} \mathrm{~Pb}$ versus ${ }^{207} \mathrm{~Pb} /{ }^{204} \mathrm{~Pb}$ para as frações de lixiviado L1 a L4 obtidas de piroxênio e granada.

Figura 6. Diagramas isocrônicos ${ }^{206} \mathrm{~Pb} /{ }^{204} \mathrm{~Pb}$ versus ${ }^{207} \mathrm{~Pb} /{ }^{204} \mathrm{~Pb}$ para a fração $\mathrm{L} 2 \mathrm{da}$ mina Brejuí.

Figura 7. Diagramas isocrônicos ${ }^{206} \mathrm{~Pb} /{ }^{204} \mathrm{~Pb}$ versus ${ }^{207} \mathrm{~Pb} /{ }^{204} \mathrm{~Pb}$ para a fração $\mathrm{L} 2 \mathrm{da}$ mina Bodó.

Figura 8. Diagramas isocrônicos ${ }^{206} \mathrm{~Pb} /{ }^{204} \mathrm{~Pb}$ versus ${ }^{207} \mathrm{~Pb} / 204 \mathrm{~Pb}$ para a fração L3 da mina Bonfim.

Figura 9. Diagrama Concórdia e histograma de idades ${ }^{206} \mathrm{~Pb} /{ }^{238} \mathrm{U}$ para os granitos Cerro-Corá e Picuí. 


\section{LISTA DE TABELAS}

\section{CAPÍTULO 2}

Table 1. SHRIMP U-Pb zircon data for augen gneisses and metaleucogabbro from the northeastern Borborema Province.

Table 2. ID-TIMS $\mathrm{Nd}$ isotopic data and related parameters for augen gneisses and metaleucogabbro from the northeastern Borborema Province.

\section{CAPÍTULO 3}

Table 1. U-Pb SHRIMP isotopic data for zircon grains from the Totoró and Acari plutons, as well as the Santa Luzia anatexite.

\section{CAPITULO 4}

Tabela 1. Procedimentos para separação mecânica de minerais calciosilicatados.

Tabela 3. Detalhes do procedimento para lixiviação de minerais calciosilicatados, scheelita e molibdenita. 


\section{SUMÁRIO}

AGRADECIMENTOS

RESUMO

ABSTRACT

LISTA DE FIGURAS

LISTA DE TABELAS

SUMÁRIO

\section{CAPÍTULO 1}

1. APRESENTAÇÃO 2

2. SÍNTESE GEOLOGICA DO PRECAMBRIANO DA FAIXA SERIDO 3

2.1 Introdução 3

2.2 O Complexo Caicó e as intrusões graníticas $G_{2} \quad 4$

2.3 Litoestratigrafia do Grupo Seridó $\quad 6$

2.4 O magmatismo granítico brasiliano e mineralizações de W-Mo

3. OBJETIVOS E JUSTIFICATIVA

CAPítULO 2 - Long-lived Paleoproterozoic granitic magmatism in the northeastern Borborema Province, NE Brazil

Abstract

1. INTRODUCTION 12

2. GEOLOGICAL SETTING 13

2.1 The Caicó basement complex 14

2.2 Previous geochronological results for the G2 augen gneisses 16

2.3 The Orós, Jaguaribe, Serra de São José and Seridó belts 17

3. ZIRCON U/Pb GEOCHRONOLOGY 18

3.1 Sampling and analytical methods 18

3.2 Results $\quad 19$

3.2.1 Caicó Complex in Santa Luzia region 19

3.2.2 Sheeted augen and leucogneisses 19

3.2.3 The batholitic plutons 23

4. Sm-Nd ISOTOPE DATA 24

5. DISCUSSION 25

6. CONCLUSION 28

CAPITULO 3 - Timing of the HT/LP transpression in the Neoproterozoic Seridó Belt (Borborema Province, Brazil): constraints from U-Pb (SHRIMP) geochronology and implications for the connections between NE Brazil and West Africa

$\begin{array}{ll}\text { Abstract } & 36\end{array}$

$\begin{array}{ll}\text { 1. INTRODUCTION } & 37\end{array}$ 
2. GEOLOGICAL SETTING 39

2.1 The Seridó belt $\quad 39$

2.2 Geochronology of the Totoró and Acari plutons $\quad 41$

2.2.1 Sampling and analytical methods $\quad 41$

2.2.2 Results 43

2.3 The anatexite of Santa Luzia $\quad 45$

2.3.1 Anisotropy of Magnetic Susceptibility

2.3.2 Geocronology $\quad 52$

3. DISCUSSION 52

3.1 Significance of magnetic fabrics in the migmatite 52

3.2 Timing of the HT deformational event

3.3 Implications for the connections with the Nigeria shield 56

4. CONCLUSION 57

\section{CAPÍTULO 4}

1. INTRODUÇÃO 65

2. INFORMAÇŐES SOBRE AS METODOLOGIAS ADOTADAS NO PROJETO 68

2.1 Separação mecânica de minerais 68

2.2 Rotinas analíticas Sm-Nd e PbSL no CPGeo

2.3 Rotina analítica Re-Os $\quad 70$

2.4 Rotina U-Pb SHRIMP em zircão

3. RESULTADOS 72

3.1 Isócronas Sm-Nd para as paragêneses de alta e baixa temperatura nas minas Brejuí e Bodó

3.2 Isócronas $\mathrm{Sm}-\mathrm{Nd}$ para as paragêneses de alta e baixa temperatura na mina Bonfim

3.3 Isócronas $\mathrm{Pb}-\mathrm{Pb}$ por lixiviação

3.3.1 Mina Brejuí

3.3.2 Mina Bodó

3.3.3 Mina Bonfim

3.4 Idades Re-Os em molibdenitas

3.5 Idades U-Pb SHRIMP em zircão para os plútons de Acari, Totoró, Picuí e Cerro Corá

4. CONCLUSÃO

CAPíTULO 5

COMENTÁRIOS FINAIS 


\section{CAPÍTULO 1}

Este capítulo traz os comentários iniciais da presente Tese de Livre-Docência, os quais incluem Apresentação, Síntese Geológica do Precambriano da Faixa Seridó, Objetivos e Justificativa. 


\section{APRESENTAÇÃO}

O presente documento foi elaborado em cumprimento às exigências do concurso de Livre-Docência junto ao Departamento de Mineralogia e Geotectônica do Instituto de Geociências da USP, na área de Geologia Isotópica. O escopo inclui a contribuição dada pela autora ao conhecimento sobre a evolução geológica precambriana do setor nordeste da Província Borborema fundamentada principalmente na obtenção de dados geocronológicos $\mathrm{Sm}-\mathrm{Nd}, \mathrm{U}-\mathrm{Pb}$ in situ em zircão e Re-Os em molibdenita.

A região de estudo coincide geograficamente com a totalidade do estado do Rio Grande do Norte e a parte mais setentrional do estado da Paraíba. Do ponto de vista geológico, os limites a sul e a oeste dessa região são feitos pelas zonas de cisalhamento Patos e Portalegre, a norte pelas coberturas fanerozoicas da Bacia Potiguar e a leste pelos sedimentos recentes da Formação Barreiras. Essa região conhecida como Faixa Seridó (incluindo seu embasamento) representa uma área clássica de estudos do Precambriano no Nordeste do Brasil tendo sido alvo de trabalhos pioneiros de cartografia geológica do início da década de 70 (p.ex., Ebert, 1969, 1970; Ferreira e Albuquerque, 1969; Santos, 1973). A faixa caracteriza-se pela ocorrência de rochas dominantemente proterozoicas com configuração tectônica condicionada pela distribuição de zonas de cisalhamento de importância crustal ou mesmo litosférica, instaladas ou reativadas durante a orogenia Brasiliana, no Neoproterozoico.

$\mathrm{Na}$ ausência de evidências litoestratigráficas ou tectônicas conclusivas que expliquem várias questões ainda em aberto sobre a evolução precambriana da Faixa Seridó, a geocronologia torna-se uma ferramenta imprescindível. Apesar do vasto conhecimento cartográfico, o conjunto de dados geocronológicos atualmente disponível é pouco expressivo quando considerado o volumoso plutonismo cartografado, ordenado na hierarquia de suítes granitóides $G_{1}, G_{2}$ e $G_{3}$, como proposto por Jardim de Sá et al. (1981). Para as suites $G_{1}$ e $G_{2}$, por exemplo, os dados geocronológicos disponíveis até início da década de 90 eram em sua maioria limitados a idades $\mathrm{Rb}-\mathrm{Sr}$ e $\mathrm{K}-\mathrm{Ar}$, largamente susceptíveis ao resetting brasiliano. Os trabalhos de Hackspacher et al. (1990), Legrand et al. (1991), Dantas (1992) e Souza et al. (1993) trouxeram as primeiras idades U-Pb (TIMS) e Pb-Pb por evaporação em zircão para os ortognaisses da suite $\mathrm{G}_{1}$, agrupadas entre 2,25 - 2,15 $\mathrm{Ga}$. Para a suite $\mathrm{G}_{2}$, no entanto, as idades existentes até o momento ainda eram inconclusivas em definir o intervalo preciso da cristalização de seus protólitos. Para a suíte $G_{3}$ o intervalo proposto era de c. $580-575 \mathrm{Ma}$ determinado em granitos que intrudem o embasamento ocidental da Faixa Seridó (Tese de Doutorado de Trindade, 1999) e no fácies diorítico do plúton de Acari (Leterrier et al., 1994). Em ambos os casos os dados referem-se à idades U-Pb (ID-TIMS) em zircão. É importante ressaltar que boa parte dessas contribuições tem sido referenciadas em resumos de 
congressos e simpósios de cunho nacional ou regional, ou ainda no corpo de dissertações e teses de acesso restrito.

Como contribuições científicas importantes destacam-se o conjunto de dados geocronológicos U-Pb SHRIMP de um núcleo (neo- a meso-)arqueano ainda preservado no domínio oriental do embasamento (ver Dantas et al., 2004). Outra informação geocronológica importante para a região diz respeito ao estudo de proveniência das unidades metasedimentares que constituem o Grupo Seridó apresentado em Van Schmus et al. (2003), cuja idade máxima de deposição foi definitivamente posicionada no Neoproterozoico dada a presença de população expressiva de zircões com idades em c. 650 - $630 \mathrm{Ma}$.

A presente tese reúne um conjunto de dados geocronológicos sobre a Faixa Seridó e seu embasamento. Todos os resultados aqui apresentados são inéditos, reunidos ao longo dos últimos anos a partir do interesse mútuo desta autora e de colegas sobre a referida temática. $\mathrm{O}$ capítulo inicial deste documento apresenta revisão literária sobre o atual conhecimento geológico da faixa, incluindo também os objetivos e justificativa para o tema proposto. $O$ Capítulo 2 apresenta e discute dados geocronológicos obtidos em intrusões graníticas gnaissificadas do embasamento (suíte $G_{2}$ de Jardim de Sá et al., 1981) recentemente publicados no periódico Journal of South American Earth Sciences. O Capítulo 3 apresenta dados geocronológicos combinados a padrões estruturais referentes a intrusivas máficas e félsicas (suíte $\mathrm{G}_{3}$ ) e a relação entre estas e o timing da deformação/metamorfismo regional de alta temperatura; o artigo está aceito para publicação no Gondwana Research. O quarto capítulo reúne dados geocronológicos dos pulsos magmáticos mais tardios (leucogranitos da suíte $\mathrm{G}_{3}$ ) e sua relação temporal com as mineralizações de W-Mo que ocorrem na faixa. Por fim, os comentários finais são apresentados no último capítulo.

\section{SÍNTESE GEOLÓGICA DO PRECAMBRIANO DA FAIXA SERIDÓ}

\subsection{Introdução}

Diversos modelos de compartimentação tectônica da PB foram propostos ao longo das últimas décadas, evoluídos a partir de trabalhos pioneiros como o de Brito Neves (1975) que introduziu os termos 'faixas dobradas' e 'maciços medianos' cunhados com referência ao Ciclo Brasiliano, e de Almeida et al. (1977) que a definiu como Província de Dobramentos do Nordeste (ver ainda Brito Neves, 1983; Santos e Brito Neves, 1984; Santos et al., 1984). Dados estruturais e geocronológicos balizaram as novas propostas que passaram a dar ênfase em explicar a atuação do Ciclo Brasiliano como responsável pela geração e/ou retrabalhamento da crosta pretérita na Província Borborema. A partir de então, os termos 'faixas dobradas' e 
'maciços medianos' foram substituídos pela terminologia mais moderna de sequências supracrustais e seus respectivos substratos de embasamento gnáissico, dando lugar a debates sobre o caráter monocíclico ou policíclico destas sequências, dispostas sobre um embasamento reconhecidamente polideformado. Com $\circ$ avanço do conhecimento geocronológico da província alguns autores dividiram-na em três sub-províncias: (1) Setentrional, compreendendo os domínios Médio Coreaú, Ceará Central e Rio Grande do Norte, (2) Central, limitada pelas zonas de cisalhamento Patos e Pernambuco - ou simplesmente Zona Transversal; e (3) Meridional, definida entre a sub-província Central e o Craton São Francisco (ver Van Schmus et al., 1995; Brito Neves et al., 2000; Santos et al., 2000).

A área de estudo está inserida na parte setentrional da PB. Esse segmento encerra os registros geológicos mais antigos cartografados na província, representados por núcleos reliquiares de crosta neoarqueana com idades c. 2,8 - 2,5 Ga (Complexo Granjeiro, Silva et al., 1997; Maciço de Tróia, Fetter, 1999) e por um segmento com história dominada por reciclagem crustal desde o Paleo- até Mesoarqueano (3,4 a 3,1 Ga) com pequena contribuição juvenil a c. 3,2 Ga e consolidação final a c. 2,7 Ga - o Maciço São José do Campestre (Dantas et al., 1998, 2004). O arcabouço paleoproterozoico inclui terrenos gnáissico-migmatíticos de composição tonalítica a granodiorítica com idades desde c. 2,35 a 2,15 Ga (Hackspacher et al., 1990; Dantas, 1992; Souza et al., 1993, 2008; Jardim de Sá, 1994; Fetter et al., 2000; Santos et al., 2008, 2009) os quais envolvem os núcleos arqueanos e constituem o embasamento de sequências metavucanosedimentares paleoproterozoicas mais jovens (Orós-Jaguaribe e Serra de São José, entre 1,8 - 1,6 Ga; Sá, 1991; Cavalcante, 1999) e neoproterozoicas (MartinópoleUbajara e Seridó entre c. 780 - 630 Ma; p.ex., Fetter et al., 2003; Van Schmus et al., 2003) que, por sua vez, constituem substrato regional para vários episódios magmáticos cronocorrelatos.

\subsection{Complexo Caicó e as intrusões graníticas $G_{2}$}

O status atual de conhecimento da região do Seridó destaca a presença de amplo substrato de embasamento gnáissico-migmatítico paleoproterozoico (c. 2,2 Ga), cuja denominação regional é Complexo Caicó. Esse complexo inclui uma sequência metavulcanosedimentar, pouco preservada, constituída de paragnaisses e anfibolitos com lentes de kinzigitos, quartzitos, formações ferríferas e, mais raramente, mármores e rochas calciossilicatadas (p. ex., Souza, 1991; Dantas, 1992). Essa sequência é intrudida por rochas metaplutônicas de composição tonalítica-granítica interpretadas como produtos de diferenciação de magmas parentais metaluminosos, de afinidade cálcio-alcalina e alto-K. A assinatura geoquímica-isotópica dessas rochas indica derivação a partir da fusão parcial (10- 
$20 \%$ ) de um manto Iherzolítico enriquecido em elementos incompatíveis (Souza, 1991; Souza et al., 1993; Jardim de Sá, 1994; Souza et al., 2008). A presença particular de anomalias geoquímicas de $\mathrm{Ta}-\mathrm{Nb}$ e $\mathrm{Ti}$ indica que o enriquecimento teria sido promovido por subducção através da interação com líquidos adakíticos (Souza et al., 2008). Valores tanto negativos quanto positivos para o parâmetro $\varepsilon N d$ sugerem a consolidação do substrato Caicó a partir de sucessivos episódios de colagem entre arcos magmáticos oceânicos e continentais, estes últimos provavelmente resultantes da reciclagem de um substrato ainda mais antigo, de idade arqueana (Dantas, 1997; Dantas et al., 2004; Souza et al., 2008). Apesar da discussão sobre a gênese desse complexo de embasamento, o timing preciso de sua amalgamação como protocontinente Caicó ainda é uma questão em aberto, e sem dúvida uma peça fundamental para reconstruir a história geológica precambriana da região.

Citando a cronologia proposta em Jardim de Sá et al. (1981) para as unidades granitóides reconhecidas no âmbito da Faixa Seridó, o Complexo Caicó seria o conjunto mais antigo correspondendo a um substrato siálico para a intrusão episódica de suítes ígneas mais jovens. Essas intrusões de geometria ora definida por sheets tabulares ora por corpos batolíticos são hoje representadas por granitóides porfiríticos gnaissificados (os augen gnaisses $G_{2}$ daqueles autores), principalmente cartografados no embasamento ocidental da faixa, e interpretados à luz de duas correntes de pensamento antagônicas. O trabalho de Jardim de Sá et al. (1995) traz uma síntese das discussões anteriores sobre a utilização da suite $\mathrm{G}_{2}$ como marcador estrutural e cronológico de uma orogênese paleoproterozoica (o Transamazônico) na Faixa Seridó. Dois dos critérios estabelecidos para essa interpretação dizem respeito às supostas relações de intrusão desses augen gnaisses com o Grupo Seridó (o que os distinguiria dos ortognaisses Caicó), e a presença de um fabric tangencial penetrativo, de alta temperatura, truncando estruturas mais antigas mapeadas apenas nos ortognaisses do embasamento. Como argumento para a defesa de uma evolução policíclica para a Faixa Seridó, as idades c. 1,95 Ga até então disponíveis para esses corpos granitóides (ver Macedo et al., 1984; Jardim de Sá et al., 1987; Legrand et al., 1991) representariam, na concepção daqueles autores, a melhor estimativa de idade para um evento tectonometamórfico paleoproterozoico. Por outro lado, Caby (1989) e Archanjo e Salim (1986) concideraram que a evolução da faixa teria ocorrido no Neoproterozoico, e propuseram que os augen gnaisses representariam intrusões anorogênicas pré-brasilianas que precederiam a deposição da unidade metapelítica correspondente à Formação Seridó (ver adiante).

Apesar da divergência nas interpretações, a idade de colocação dos magmas progenitores dos augen gnaisses (suíte $\mathrm{G}_{2}$ ) não estava determinada com precisão, o mesmo aplicando-se às estruturas tangenciais que controlam seu alojamento. Parte dos dados geocronológicos referiam-se à isócronas (ou errócronas) $\mathrm{Rb}-\mathrm{Sr}$ com idades fortemente variáveis entre c. 2,1 e 1,75 Ga, com erros associados muito elevados. O único dado U-Pb 
obtido nessas rochas foi publicado por Legrand et al. (1991) correspondendo a uma discórdia fornecida pelo alinhamento de três frações multigrãos de zircão (técnica ID-TIMS) próximo ao intercepto inferior sugerindo, portanto, que o resultado em c. 1,95 Ga poderia ser interpretado como idade mínima de cristalização.

\subsection{Litoestratigrafia do Grupo Seridó}

Já o Grupo Seridó marca a implantação de um ciclo geodinâmico próprio, independente da história precoce de acresção crustal contada a partir de seu embasamento. Assim como para os augen gnaisses, duas hipóteses foram formuladas para explicar a cronoestratigrafia de suas unidades. Na síntese apresentada por Jardim de Sá e Salim (1980) a coluna litoestratigráfica estaria organizada em uma subdivisão tríplice que incluiria: (i) Formação Jucurutu, basal, constituída dominantemente por biotitatepidoto paragnaisses, contendo intercalações de mármores e rochas calciossilicatadas, micaxistos, quartzitos, formações ferríferas, e metavulcânicas; (ii) Formação Equador, intermediária e lateralmente descontínua, composta por quartzitos e metaconglomerados mono- e polimíticos, além de raras intercalações de micaxistos e rochas calciossilicatadas; e (iii) Formação Seridó, no topo, constituída dominantemente por micaxistos feldspáticos ou aluminosos, com intercalações subordinadas de mármores, rochas calciossilicatadas, paragnaisses, metavulcânicas, quartzitos e metaconglomerados.

A posição superior dos micaxistos Seridó é consensual. No entanto, a proposta formalizada por Archanjo e Salim (1986) defende que o Grupo Seridó seria organizado em duas grandes unidades cronoestratigráficas, separadas por uma discordância regional (ver também Caby, 1989; Caby et al., 1991) que seriam: (i) o Grupo Jucurutu, reunindo as formações Jucurutu e Equador, representando uma sequência plataformal mais antiga (paleoproterozoica, com base nas idades c. 1,95 Ga dos augen gnaisses) e (ii) o Grupo Seridó, incluindo as formações Parelhas e Seridó, interpretado como depósito sin-orogênico neoproterozoico. A inserção de uma nova unidade, a Formação Parelhas, foi justificada pela presença de conglomerados poligênicos localmente mapeados na base da Formação Seridó que refletiria um lapso temporal de sedimentação.

A longa discussão sobre um caráter mono- ou policíclico para a história do Grupo Seridó foi resolvida com os dados de proveniência sedimentar publicados por Van Schmus et al. (2003) para as unidades Jucurutu e Seridó. As idades U-Pb em zircões detríticos confirmaram a validade das idades $t_{D M}$ entre c. 1,6 - 1,2 Ga que já indicavam a contribuição de material jovem como preenchimento da bacia (Van Schmus et al., 1995), sendo crescente a participação de fontes neoproterozoicas em direção ao topo da sequência. $O$ limite máximo 
para a deposição foi estabelecido entre 650 - 630 Ma a partir das idades dos zircões mais jovens. Com base nesses resultados, tornou-se imprescindivel repensar a história paleoproterozoica da Faixa Seridó sabendo-se que se os augen gnaisses $\mathrm{G}_{2}$ seriam de fato marcadores de um evento deformacional antigo, como postulado, essa deformação não teria afetado a sequência supracrustal agora reconhecida como neoproterozoica. E qual seria, então, a idade da deformação tangencial impressa em unidades paleo- (o embasamento Caicó) e neoproterozoica (o Grupo Seridó)?

\subsection{O magmatismo granítico brasiliano e mineralizações de W-Mo}

Os granitóides brasilianos representam a suíte $G_{3}$ de Jardim de Sá et al. (1981) e ocorrem em toda extensão da faixa, intrudindo embasamento e metasedimentos indiscriminadamente. São representados por termos composicionais que incluem granitos (monzo e sienogranitos a quartzo monzonitos) porfiríticos tipo dente-de-cavalo, dominantes, em frequente associação de mixing ou mingling com rochas básico-intermediárias (gabros, dioritos, quartzo dioritos) de natureza shoshonítica. A relação genética entre essas duas suites granitóides foi explorada na Tese de Doutorado de E.F. Jardim de Sá, a partir de dados geoquímicos. Em termos gerais, os resultados mostraram razoável incompatibilidade com a hipótese de que processos de mistura de magmas tenham sido os principais responsáveis pelas variações geoquímicas observadas nos vários plútons estudados. No que diz respeito à assinatura isotópica dessas rochas, Hollanda et al. (2003) comprovam o envolvimento de uma fonte tipo manto litosférico enriquecido para explicar as razões iniciais de $\mathrm{Sr}$ e $\mathrm{Nd}$ fortemente radiogênicas nos membros básicos-intermediários, também sugerindo a improbabilidade de que efeitos isolados de mistura seriam o principal mecanismo petrogenético na gênese e diferenciação das suites de granitos e gabros-dioritos.

A diversidade composicional das suítes granitóides brasilianas na Faixa Seridó é também reforçada pela ocorrência menos expressiva de (monzo)granitos equigranulares de afinidade cálcio-alcalina potássica, granitos a quartzo-alcáli feldspato granitos, e ainda outros tipos alcalinos com composição quartzo-mangerítica a charnockítica (Nascimento et al., 2000). Somam-se a esses a importância volumétrica de corpos pegmatíticos tardi-brasilianos de c. 515 - 510 Ma constituindo a província pegmatítica do Seridó (Santos, et al., 1973; Araújo et al., 2001; Baumgartner et al., 2006).

Apesar de bem estudados do ponto de vista cartográfico e petrológico as idades disponíveis ainda são insuficientes para montar a cronologia precisa desses vários representantes magmáticos na faixa. Essa carência torna-se crítica quando levado em conta a sua ampla utilização como marcadores cronológicos de um evento orogênico brasiliano na 
região, defendida com base na coerência cinemática entre a fábrica magmática observada nos plútons e aquela desenvolvida por recristalização subsolidus nas encaixantes (e, não raro, nas bordas desses). As idades reportadas são em sua maioria fornecidas por isócronas (e também errócronas) $\mathrm{Rb}-\mathrm{Sr}$ e poucos dados U-Pb em zircão (ID-TIMS) com valores entre c. 630 - 515 Ma, ou mais precisamente em 580 × 30 Ma (ver Jardim de Sá, 1994 para maiores detalhes).

Ainda sobre o magmatismo brasiliano, é importante mencionar sua provável associação genética com a ampla ocorrência de depósitos hidrotermais de W-Mo em skarns gerados preferencialmente no contato entre paragnaisses e mármores da Formação Jucurutu e, subordinadamente, como bolsões dentro destes litotipos (p.ex., Lima et al., 1980). A Tese de Doutorado de Salim (1993) inclui significativo acervo de dados geoquímicos, de química mineral e inclusões fluidas para as paragêneses calciosilicatadas (e sulfetos associados) de uma das maiores ocorrências na região do Seridó - a mina Brejuí (RN). Juntos, os dados indicam que o fluxo térmico proveniente de intrusões ígneas associado à percolação de fluidos magmáticos canalizados nas zonas de cisalhamento regionais seriam os principais responsáveis pelas transformações metamórficas/hidrotermais skarníticas. Dada a proximidade da mina Brejuí com o plúton de Acari a idade dessas mineralizações tem sido extrapolada para a idade de c. 580 Ma conferida a esse corpo granítico.

\section{OBJETIVOS E JUSTIFICATIVA}

O objetivo dessa tese é apresentar um conjunto de dados geocronológicos $\mathrm{Sm}-\mathrm{Nd}$ e U$\mathrm{Pb}$ (SHRIMP) em zircão para algumas das suítes magmáticas que constituem a Faixa Seridó. Os alvos são os augen gnaisses (suíte $G_{2}$ ) e os granitóides brasilianos (suíte $G_{3}$ ) representando dois dos três episódios magmáticos (se também considerado o plutonismo Caicó) que edificaram o arcabouço precambriano da região. Além de estabelecer sua cronologia precisa, as idades $\mathrm{U}-\mathrm{Pb}$ obtidas especificamente para o magmatismo brasiliano foram também utilizadas para dar suporte à hipótese de associação genética com os depósitos de W-Mo de ampla ocorrência na Faixa Seridó. Para essa correlação fez-se também necessária a datação direta desses depósitos. Aqui optamos pelo método Re-Os aplicado à molibdenita que ocorrem em associação paragenética com a scheelita.

As questões que levaram à presente abordagem dizem respeito a:

1. No tocante às unidades mais antigas, e embora a idade dos ortognaisses do embasamento Caicó esteja estabelecida em c. 2,15 Ga (Macedo et al., 1984, 1991; Hackspacher et al., 1990; Dantas, 1992; Souza et al., 1993), a datação precisa dos augen gnaisses $\mathrm{G}_{2}$ permanecia incerta a despeito de sua importante exposição como unidade de 
mapeamento e de sua contraditória interpretação como provável (ou não) marcador temporal de um evento deformacional antigo (ver Jardim de Sá et al., 1995 e a réplica em Archanjo e Legrand, 1997). Com a publicação da idade máxima neoproterozoica para a deposição do Grupo Seridó (cf. Van Schmus et al., 2003), a questão da evolução policíclica versus monocíclica ganhou novos contornos. Se as relações de intrusão da suíte $G_{2}$ na base do $G$ rupo Seridó estão mantidas seria razoável supor que os protólitos porfiríticos dos augen gnaisses tiveram seu alojamento durante o Neoproterozoico. Nesse caso, os augen gnaisses representariam intrusões sin-orogênicas brasilianas dada a coerência entre as tramas da intrusão e de sua encaixante. Por outro lado, os augen gnaisses poderiam ser também interpretados como intrusões anorogênicas pré-brasilianas em consistência com o modelo monocíclico. A aceitação consensual de qualquer uma das possibilidades dependeria exclusivamente da obtenção de dados geocronológicos confiáveis.

2. Tendo em vista o caráter pervasivo do Ciclo Brasiliano na Faixa Seridó e a continuidade estrutural observada entre a trama metamórfica de alto grau evidente nas zonas de cisalhamento ductéis regionais e a trama magmática dos granitos neoproterozoicos, os mesmos representariam de fato um marcador cronológico potencial da deformação brasiliana. Para definir o timing preciso desse evento deformacional, foi realizado estudo combinado usando padrões de foliação/lineação definidos pela ASM de alguns corpos magmáticos da faixa (Acari e Santa Luzia) visando entender os seus mecanismos de alojamento e explorar suas relações com a deformação regional. Uma vez definida essas relações, utilizamos a geocronologia U-Pb SHRIMP em zircão para datar o magmatismo e, portanto, a deformação.

3. Para reconhecer a associação genética entre as mineralizações de W-Mo e o magmatismo neoproterozoico buscou-se datar os principais depósitos reconhecidos na Faixa Seridó, bem como os corpos ígneos em proximidade espacial com as mineralizações. Além dos plútons de Acari e Totoró mais dois corpos leucograníticos foram também datados pelo método U-Pb SHRIMP em zircão. A idade do evento mineralizante foi definida nas minas Brejuí, Bodó e Bonfim através da datação direta Re-Os em molibdenitas e os resultados comparados com aqueles obtidos para os corpos ígneos. 


\section{CAPÍTULO 2}

Artigo Long-lived Paleoproterozoic granitic magmatism in the Serido-Jaguaribe domain, Borborema Province - NE Brazil, publicado no periódico Journal of South American Earth Sciences (Elsevier), 2011, vol. 32(4): 287-300. 
Long-lived Paleoproterozoic granitic magmatism in the northeastern Borborema Province, NE Brazil

Maria Helena B.M. Hollanda', Carlos J. Archanjo ${ }^{1}$, Laécio C. Souza ${ }^{2}$, Liu Dunyi ${ }^{3}$, Richard Armstrong ${ }^{4}$

1. Instituto de Geociências, Universidade de São Paulo, Rua do Lago 562, 05508-080, Săo Paulo, Brazil.

2. Departamento de Geologia, Universidade Federal do Rio G. Norte, 59000-000, Natal, Brazil.

3. Beijing SHRIMP Center, Chinese Academy of Geological Sciences, Beijing 10037, China.

4. Research School of Earth Sciences, Australian National University, Canberra, ACT 0200, Australia.

\begin{abstract}
The northeastern part of the Borborema Province is dominated by Paleoproterozoic migmatitic tonalitic to granitic orthogneisses (Caicó Complex) that are the basement for younger, metavolcanosedimentary rock assemblages. Within this complex gneissified, porphyritic metagranitoid rocks (the G2-type augen gneisses) are fairly common and supposed to define a synorogenic magmatism at c. $2.0 \mathrm{Ga}$. New U-Pb (SHRIMP) on zircons and Sm-Nd data shows that these augen gneisses do not differ significantly from the metaplutonic rocks of the basement complex regarding their nature and emplacement age of the primary magmas. U-Pb ages cluster in a time interval between 2.17 and $2.25 \mathrm{Ga}$ and are correlated with $\mathrm{Nd}$ parameters (older $t_{D M}$ model ages and negative initial eNd values) indicating an origin from recycling of an older, probably Neoa rchean crust. The regional host rocks that accommodate the augen gneiss could be c. $2.4-2.3 \mathrm{Ga}$ supracrustal sequénces presently preserved as small remnants in the Caicó Complex. The Paleoproterozoic magmatic activity extends to the Late Paleoproterozoic with the intrusion of the Serra Negra pluton (now a coarse augen gneiss) which yielded a (semi)concordant $\mathrm{U}-\mathrm{Pb}$ age of $c .1 .75 \mathrm{Ga}$. This magmatic activity, until now unsuspected in the Caicó Complex, was probably related to crustal extension and rifting over large areas that include the NE Brazil and the Nigerian shield in Africa.
\end{abstract}

\title{
Keywords
}

Borborema Province, U-Pb SHRIMP dating, Paleoproterozoic, crustal growth 


\section{INTRODUCTION}

The Borborema Province (NE Brazil) is a crustal domain of the Brasiliano-Pan African orogen in which more than a half of its Precambrian crystalline rocks were formed in the Paleoproterozoic (2.5-1.6 Ga). The province is part of a larger Neoproterozoic belt that extends farther south into the Brasília Belt and can be traced into Central Africa by means of lithologic correlations and a series of major shear zones (Fig. 1) (Caby, 1989; Trompette, 1997; Van Schmus et al., 2008). The current structural configuration resulted from diachronic Neoproterozoic (not yet precisely dated) events of tectonic collage along lithospheric- or crustalscale shear zones (Vauchez et al., 1995) in which the Patos shear zone may have constituted a major suture (Fig. 1). Another striking tectonic structure, probably also corresponding to a Neoproterozoic suture, occurs to the west along the Transbrasiliano-Kandi lineament in which juvenile Neoproterozoic continental arc rocks have been described (Fetter et al., 2003). However, it is worthwhile to note that to the north of Patos shear zone and possibly in the Central Nigerian shield high-grade Paleoproterozoic gneisses and migmatites are much more abundant than the juvenile rocks related to the Neoproterozoic orogenies (B.B.Brito Neves, this volume). This indicates that the Brasiliano-Pan African tectonic events involved mostly the recycling and reactivation of old crustal blocks, and the development of Neoproterozoic structures would have been controlled by preexisting inherited fabric.

The northeastern portion of the Borborema Province (Fig. 2) consists mostly of highgrade gneisses and migmatites forming the basement of Meso- to Neoproterozoic, often linear, volcano-sedimentary belts. A recent update of geochemical and geochronological data for these Paleoproterozoic metaplutonic rocks concluded they were derived from an enriched mantle at $c$. $2.15 \mathrm{Ga}$ in a geodynamic setting dominated by continental accretion (Souza et al., 2008, and references therein). Of particular importance in this region is a suite of coarse-grained augen gneisses that are considered synorogenic plutons (the G2 granitoids of Jardim de Sá et al., 1995) emplaced during the so called Transamazonian (c. $2.0 \mathrm{Ga}$ ) orogeny. These bodies usually contain a penetrative gentle dipping foliation and are associated with recumbent folding, which lead Bertrand and Jardim de Sá (1990) to propose that the fabric of large areas in the Borborema, Nigeria and, further north, the Hoggar shields would be Early Proterozoic in age. This model considers that the crustal melting, high-grade metamorphism and tangential tectonics in the Seridó- Jaguaribe domain would be pre-Brasiliano structures, which has significant implications for the geodynamic reconstructions across Atlantic between the NE Brazil and Africa.

The conflicting interpretations regarding the Paleoproterozoic magmatism in the northeastern part of the Borborema Province (e.g., Caby et al., 1990, 1995), particularly for the G2 granitoids, comes from the quite poor quality of the geochronological data set based mainly 
on whole-rock $\mathrm{Rb}-\mathrm{Sr}$ isochrons and inconclusive $\mathrm{U}-\mathrm{Pb}$ zircon ages. In fact, the study of zircons from a few augen gneisses using U-Pb (ID-TIMS) yielded both very discordant analyses and bimodal $\mathrm{Pb}-\mathrm{Pb}$ age patterns (Jardim de Sá et al., 1995). This paper focus on the geochronology of these old "synorogenic" granitoids, combining cathodoluminescence imaging and in situ U-Pb (SHRIMP) analysis on zircons and whole-rock Sm-Nd isotopic data. We show that the isotopic signature of the G2 magmatic suite is indistinguishable from that of metaplutonic rocks of the basement, which casts doubt the presence of a c. $2.0 \mathrm{Ga}$ orogenic event in this part of the province. In addition, our results reveal an unsuspected magmatic activity at c. $1.75 \mathrm{Ga}$ extending to the west that brings new implications on the Proterozoic crustal evolution of this geological domain.

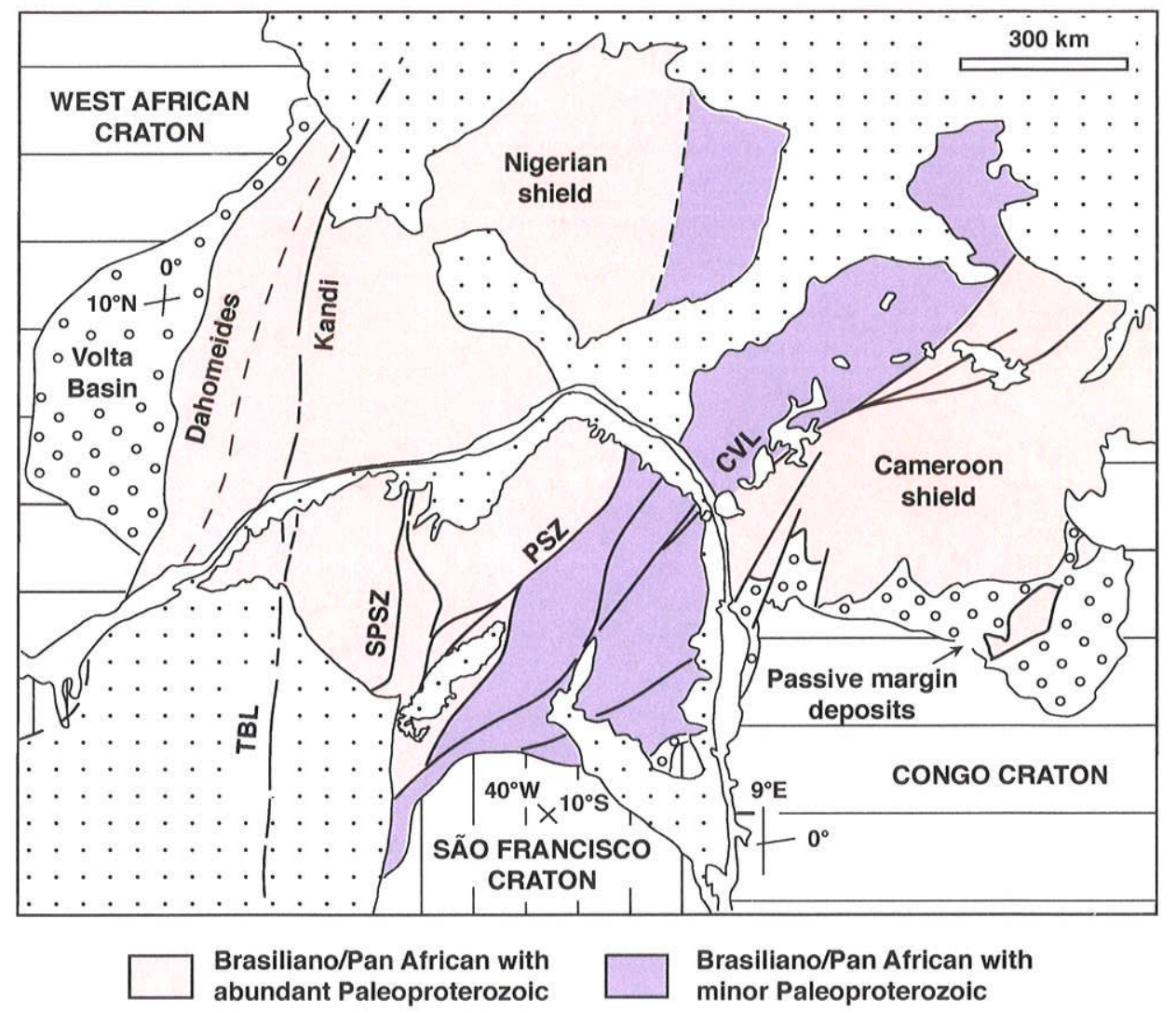

Figure 1. Pre-drift reconstruction for the main geological features of the Borborema Province (NE Brazil) and the shields of Nigeria and Cameroon in Africa. TBL, Transbrasiliano lineament; PSZ, Patos shear zone; SPSZ, Senador Pompeu shear zone; CVL, Cameroon volcanic line; dotted pattern = sedimentary cover (modified after Van Schmus et al., 2008).

\section{GEOLOGICAL SETTING}

The study area (Fig. 2) is limited to the south and west by, respectively, the Patos and Senador Pompeu transcurrent shear zones, while to the north and east it is covered by Mesozoic and Recent sediments. This crustal domain corresponds to the Rio Grande do Norte 
and Jaguaribe "terranes" but, as we will see, there are no significant geological differences between them. We will call it, hereafter, the Seridó-Jaguaribe domain. Three major geological units are identified in this domain. (a) Large areas of the basement, also known Caicó Complex, are occupied by $2.15-2.20 \mathrm{Ga}$ old high-grade orthogneisses and migmatites often invaded by late-Neoproterozoic to Cambrian granite plutons and pegmatites (not shown in figure 2). (b) A small São José de Campestre Archaean nucleus occurs to the east. It is mainly composed by trondhjemitic to granitic grey gneisses whose primary magmas were emplaced in a time interval between $3.5 \mathrm{Ga}$ and $2.7 \mathrm{Ga}$ (Dantas et al., 2004). Combined U-Pb and Sm-Nd model ages indicate that the genesis of the São José de Campestre nucleus involved juvenile crustal growth and recycling of a still older crust. (c) Finally, the Caicó Camplex hosts elongated volcanosedimentary belts deposited both the Late Paleoproterozoic (Orós, Jaguaribe and Serra de São José belts) and schist belts (Seridó) deposited in the Neoproterozoic.

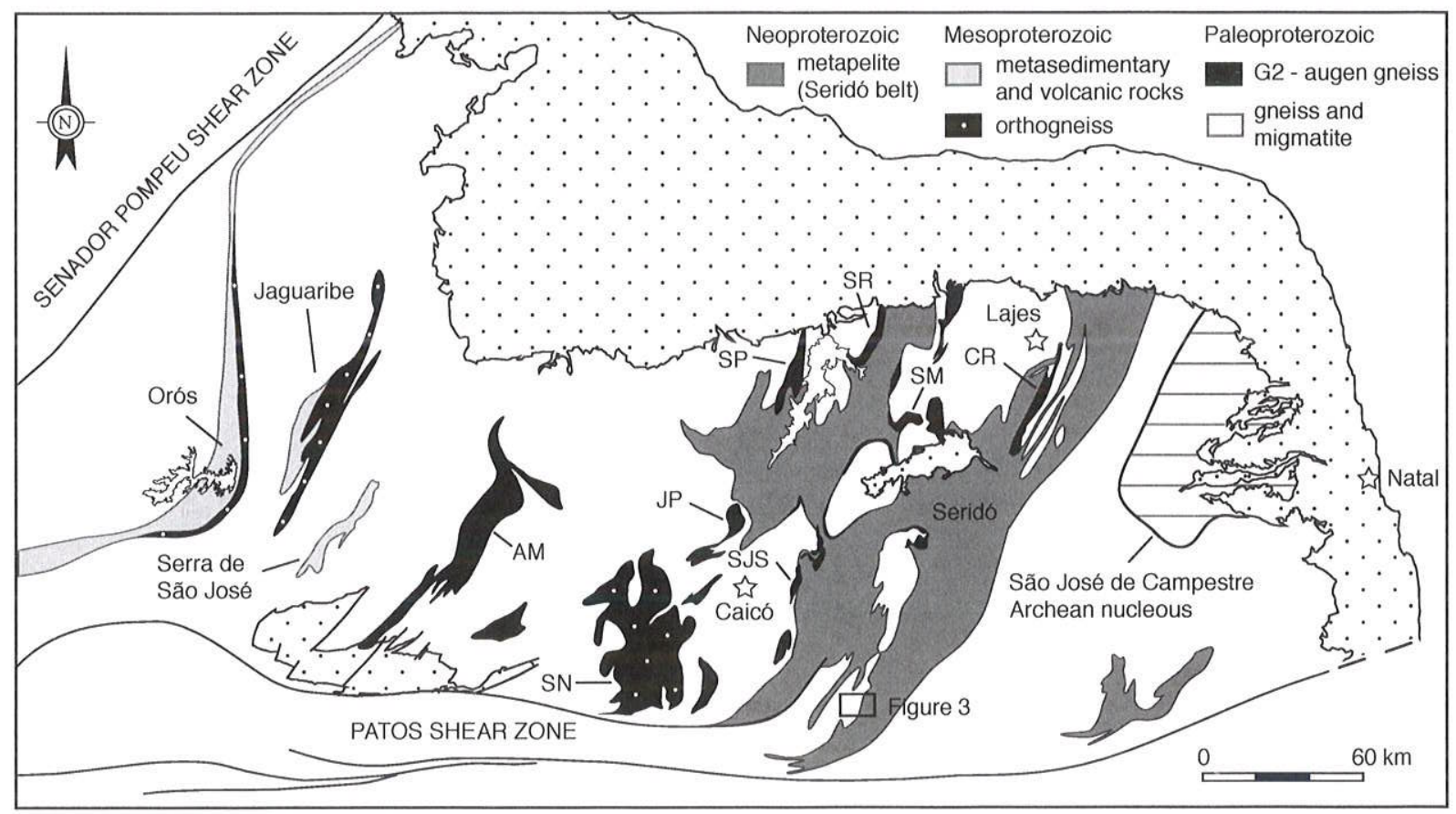

Figure 2. Simplified geological map of the Seridó-Jaguaribe domain showing the locations of the studied augen gneiss plutons (SJS, São José do Seridó; SR, São Rafael; SM, Santana do Matos; AM, Antônio Martins; SN, Serra Negra; JP, Jardim de Piranhas; SP, Serra das Pinturas; CR, Cerro Corá).

\subsection{The Caicó basement complex}

The Caicó basement complex is composed dominantly of grey variously migmatized orthogneisses encompassing high-K calc-alkaline dioritic to granitic rocks with subordinate amphibolites (Hackspacher et al., 1990; Souza et al., 1993, 2008). These rocks are usually medium-grained and may include porphyritic augen gneisses (G1 suite), which are intrusive into 
an older (usually not well preserved) supracrustal sequence (Jardim de Sá et al., 1988; Souza et al., 2008). Supracrustal rocks intercalated with orthogneisses are quite well exposed, however, southwestward of the Seridó belt in the Santa Luzia region (see Figs. 2 and 3). They comprise alternating mafic and felsic layers (banded gneisses) varying in composition from gabbro to diorite for the dark layers, and from granodiorite to tonalite for the light (felsic) layers. Lenses of marble, quartzite, kinzingite and calc-silicate gneisses are found locally associated with the banded gneisses. All units are cut by sheets of augen gneiss and mafic to ultramafic dikes (now amphibolite and hornblendite) including metaleucogabbros. In this study, we determined the crystallization ages of zircons extracted from an equigranular, medium-grained granodioritic facies corresponding to the felsic layer of a banded orthogneiss (sample BGSL) and from a metaleucogabbro (sample G2-RF) sheet intrusive in the banded gneisses.

Available $\mathrm{Rb}-\mathrm{Sr}$ isochrons and $\mathrm{U}-\mathrm{Th}-\mathrm{Pb}$ geochronological studies for the Caicó Complex define a major crustal growth episode at c. $2150( \pm 50)$ Ma, corresponding to the crystallization age for the primary magmas of the orthogneisses (Hackspacher et al., 1990; Fetter et al., 2000). The envisaged petrogenetic model involves juvenile magmas with a small older crustal component $\left(\varepsilon_{\mathrm{Nd}(2.2)}-1.87\right.$ to $0.02 ; \mathrm{T}_{\mathrm{DM}} 2.70$ to $2.53 \mathrm{Ga}$ ) extracted from metasomatized mantlederived sources, followed by fractional crystallization at crustal pressures to form an assemblage dominated by amphibole+plagioclase+magnetite (Souza et al., 2008). Such a crust-forming event, and its time-related deformational features, have been assigned to a context of a convergent orogeny that would result in a pervasive tangential fabric developed under high temperature and medium (kyanite isograde) pressure. In such an orogenic setting, granite plutons (now augen gneisses) would have been emplaced as syn- to late kinematic bodies. Presently they are exposed as tabular intrusions near the contact of the Seridó metapelite belt or, to the west of the belt, as large batholiths intrusive into the basement complex. The "G2" magmatism comprises medium to coarse grained, equigranular to porphyritic granitoids. The structural characteristics of these intrusions are (Bertrand and Jardim de Sá, 1990; Jardim de Sá et al., 1995): (i) the augen gneiss contains a penetrative, typically low-dipping foliation parallel to the axial plane of recumbent folds; (ii) they cut an older fabric of the basement which includes deformed amphibolite dikes and, (iii) close to the Seridó metapelites they form sheeted intrusions along the contact with the basement. These criteria allow mapping with some confidence the contacts of these granitoids, although in some places it can become quite difficult to distinguish an older porphyritic granitoid of the Caicó Complex (G1 type) from the G2-type augen gneisses. Therefore, some pluton's size in map view may be overestimated, which is suspected for the augen gneiss of Serra Negra (Fig. 2). 


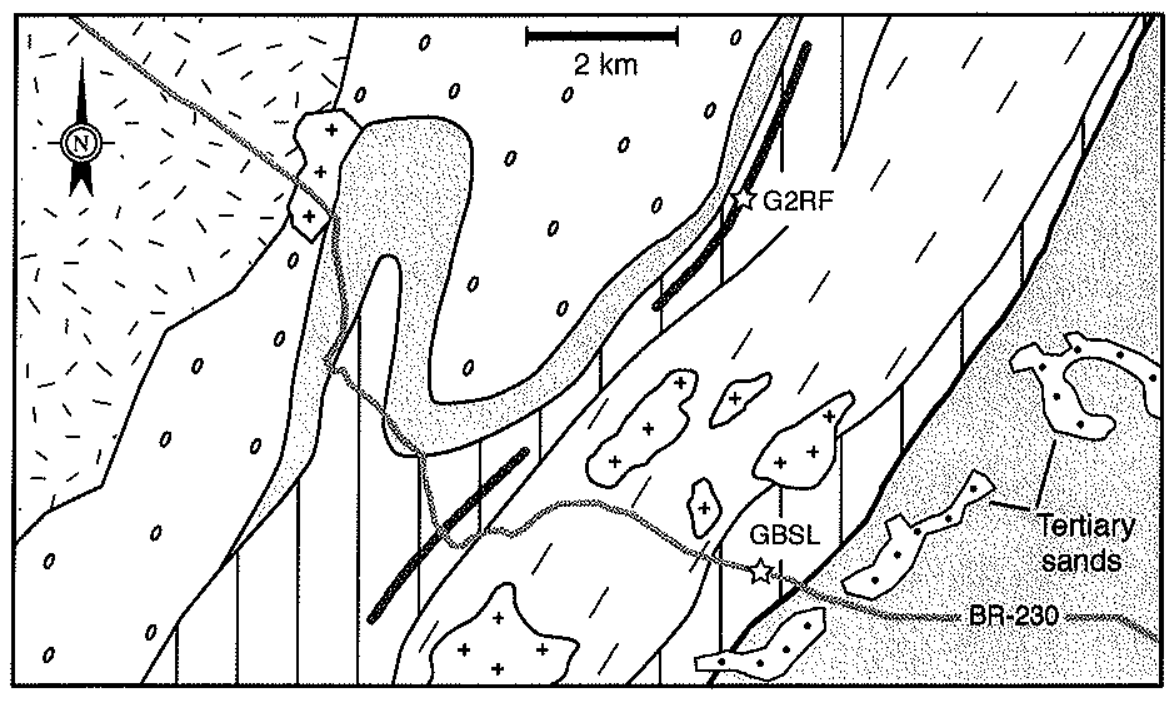

Neoproterozoic

+ pegmatite

$\square$ migmatite

metapelite, quartzite

shear zone

Paleoproterozoic

0 augen gneiss

1 leucogneiss

amphibolite, leucogabbro

kinzingite, marble,

calc-silicate gneiss

II banded gneiss

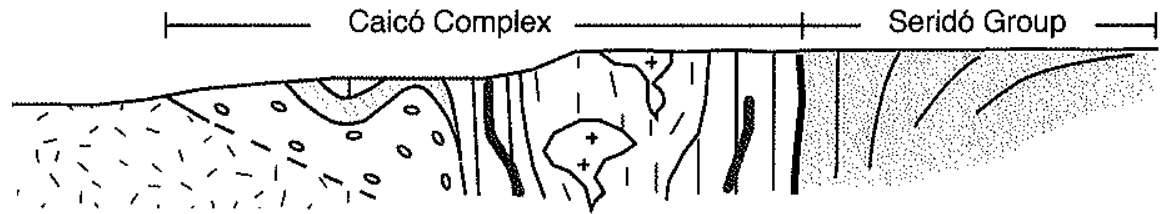

Figure 3. Geological map of the Santa Luzia region (Paraiba State) and schematic cross-section approximately parallel to the main road (BR-230). GBSL and G2RF: samples studied by U-Pb and Sm-Nd isotope systematics.

\subsection{Previous geochronological results for the $\mathrm{G} 2$ augen gneisses}

Despite importance of the G2 magmatism for understanding the Proterozoic evolution of the Seridó-Jaguaribe domain, only a few geochronological data are available, such as $\mathrm{Rb}-\mathrm{Sr}$ whole-rock isochrons, $\mathrm{Pb}-\mathrm{Pb}$ evaporation ages and ID-TIMS U-Pb zircon ages. Dating has been performed mainly on samples collected from the São Rafael augen gneiss (see location on figure 2). $\mathrm{Rb}-\mathrm{Sr}$ whole-rock isochrons of a porphyritic and pink equigranular facies yielded ages of $2007 \pm 22 \mathrm{Ma}$ and $2086 \pm 69 \mathrm{Ma}$ (Macedo et al., 1984), respectively, being interpreted as representing a pene-contemporaneous tectono-thermal event. Legrand et al. (1991) reported an ID-TIMS U-Pb upper intercept age of $1934 \pm 12$ Ma defined by three, strongly discordant zircon magnetic fractions.

Analysis of zircon grains from an augen gneiss sheet emplaced in the central domain of the Seridó metapelites (NE of Cerro Corá, see Fig. 2) just in the contact with the Caicó orthogneisses were carried out by evaporation $\mathrm{Pb}-\mathrm{Pb}$ dating (Kober technique, Jardim de Sá et al., 1995). The analyzed zircons showed a significant scattering with ages ranging from $c .1950$ to $2300 \mathrm{Ma}$, which were grouped in three mean age intervals of $1990 \pm 10 \mathrm{Ma}, 2048 \pm 20 \mathrm{Ma}$ and $2099 \pm 22 \mathrm{Ma}$. Furthermore, the age for a xenomorphic grain population yielded a mean age of $2301 \pm 16 \mathrm{Ma}$ attributed to an older component in the zircons crystals. The authors 
assume the reliability of the younger age when compared with the $\mathrm{U}-\mathrm{Pb}$ age reported in Legrand et al. (1991) and consider that the zircon ages of c. $2.0 \mathrm{Ga}$ mark a collisional event related to a Transamazonian orogeny.

\subsection{The Orós, Jaguaribe, Serra de São José and Seridó belts}

The Orós, Jaguaribe and Serra de São José belts form N- to NE-trending linear basins filled by metavolcanic-metasedimentary sequences associated with sub-alkaline porphyritic orthogneisses deposited in a continental rift system (e.g., Sá et al., 1995). The metasedimentary rocks of Orós belt consist mainly of Al-rich schist intercalated with quartzite, as well lenses of $\mathrm{Ca}$ - or $\mathrm{Mg}$-rich marble, calc-silicate rocks and carbonaceous schist. Metavolcanic rocks comprise metarhyolite, metadacite and local felsic metatuff. U-Pb zircon ages for the metavolcanics spread in the interval 1.75 - 1.8 Ga (Sá et al., 1995). The Serra de São José belt consists of a deeply eroded sequence of schists and quartzites including felsic metatuffs and metavolcanics, the later yielding a $\mathrm{Pb}-\mathrm{Pb}$ evaporation age on zircon of $\mathrm{c} .1 .75 \mathrm{Ga}$ (Cavalcante, 1999). A tonalitic orthogneiss from the basement that hosts this supracrustal sequence gaves a precise ID-TIMS U-Pb upper intercept age of c. $2.19 \mathrm{Ga}$ (Fetter et al., 2000).

The Seridó belt is a thick metasedimentary sequence consisting of a basal unit (Jucurutu Formation) comprising metaconglomerates, calc-silicatic gneisses, impure marbles and quartzites suceeded by a dominant mica schist (metaturbidite) sequence, in the upper part (Seridó Formation). In previous models the Seridó metasedimentary rocks were considered to be of Paleoproterozoic age based on their contact with the supposedly intrusive G2 augen gneisses (Bertrand and Jardim de Sá, 1990; Jardim de Sá et al., 1995). However, SHRIMP U$\mathrm{Pb}$ dating of detrital zircon from metagreywake and micaschist samples from both Jucurutu and Seridó formations showed the presence of large Neoproterozoic populations at c. 1.0 and 0.65 Ga (Van Schmus et al., 2003), indicating that the basin developed just prior or during the early phases of the Brasiliano orogeny. Sm-Nd model ages between c. 1.1 to $1.5 \mathrm{Ga}$ for the metapelites presented by those authors suggest that most siliciclastic material was derived from distal, younger sources rather than the proximal, underlying Paleoproterozoic basement. These results indicate, therefore, that an erosional discordance marks the apparently concordant contact between the augen gneisses and the metasedimentary rocks of the Seridó belt. 


\section{ZIRCON U/Pb GEOCHRONOLOGY}

\subsection{Sampling and analytical methods}

Six augen gneiss samples were collected from five plutons for SHRIMP U-Pb dating. Four samples were collected from three sheeted intrusions crop out near or along the contact with the Seridó belt: the São Rafael (SR), Santana do Matos (SM) and São José do Seridó (SJS) plutons. These intrusions consist of typical augen gneiss, except for the São Rafael pluton where it shows a mylonitic microstructure given by ribbons of quartz and highly stretched feldspar grains. In the Santana do Matos pluton we also collected a pink, equigranular hornblende-bearing gneiss intercalated within the augen gneiss. For the batholitic bodies we collected a sample of coarse augen gneiss in the Serra Negra (SN) and Antônio Martins (AM) plutons. Samples from the Santa Luzia region were collected in a felsic layer of the banded gneiss (GBSL) and in a metaleucogabbro sheet (RF) intrusive into the banded gneiss. Sampling localities are showed on Figure 2. Some geological field aspects are shown in Figure 4.

All samples were processed as normally done for zircon geochronology, using jaw crushers, wifley table, heavy liquids (bromoform and methylene iodite) and Frantz isodynamic separator techniques. Representative zircon grains were hand picked under a binocular microscope, mounted in epoxy resin and polished to approximately half their thickness in order to expose internal structure features, and gold coated. Zircons fixed in the mount were studied by transmitted and reflected light microscopy and catholuminescence $(C L)$ imaging before analysis. The spot areas (about 20-30 $\mu \mathrm{m}$ in diameter) for isotopic analysis were chosen on the igneous growth sectors in order to obtain the zircon crystallization ages.

Analyses were performed on the SHRIMP II at Beijing SHRIMP Center (China), except for zircons from the Serra Negra batholith that were analyzed on SHRIMP II at Australia National University (Camberra). Data are listed in Table 1. U-Pb isotopic data were collected in sets of five scans throughout the masses, and the TEMORA 1 reference zircon $\left({ }^{206} \mathrm{~Pb} /{ }^{238} \mathrm{U}=\right.$ $416.75 \pm 0.24 \mathrm{Ma}$; Black et al., 2003) was measured every third unknown analysis. The abundances of $\mathrm{U}, \mathrm{Th}$ and $\mathrm{Pb}$, as well as $\mathrm{Pb}$ isotope ratios, were normalized using the SL13 zircon standard $(U=238 \mathrm{ppm})$. Common $\mathrm{Pb}$ was corrected using the measured ${ }^{204} \mathrm{~Pb}$ and assuming the appropriate $\mathrm{Pb}$ model from Stacey and Kramers (1975). Data reduction was performed using SQUID/Excel macro (Ludwig, 2000). Intercept ages and statistical assessments (at 95\% confidence level) were calculated using the geochronological ISOPLOT/Excel 3.0 software of Ludwig (2003).

The discordia lines shown in the following U-Pb diagrams represent the best regression from the data set obtained for the studied samples. In order to constrain the best fits (when necessary) some analyses/spots considered to be very discordant, or significantly older or 
younger than the other, were not included either in the intercept or weighted mean age estimates. These outlier analyses are cited in text.
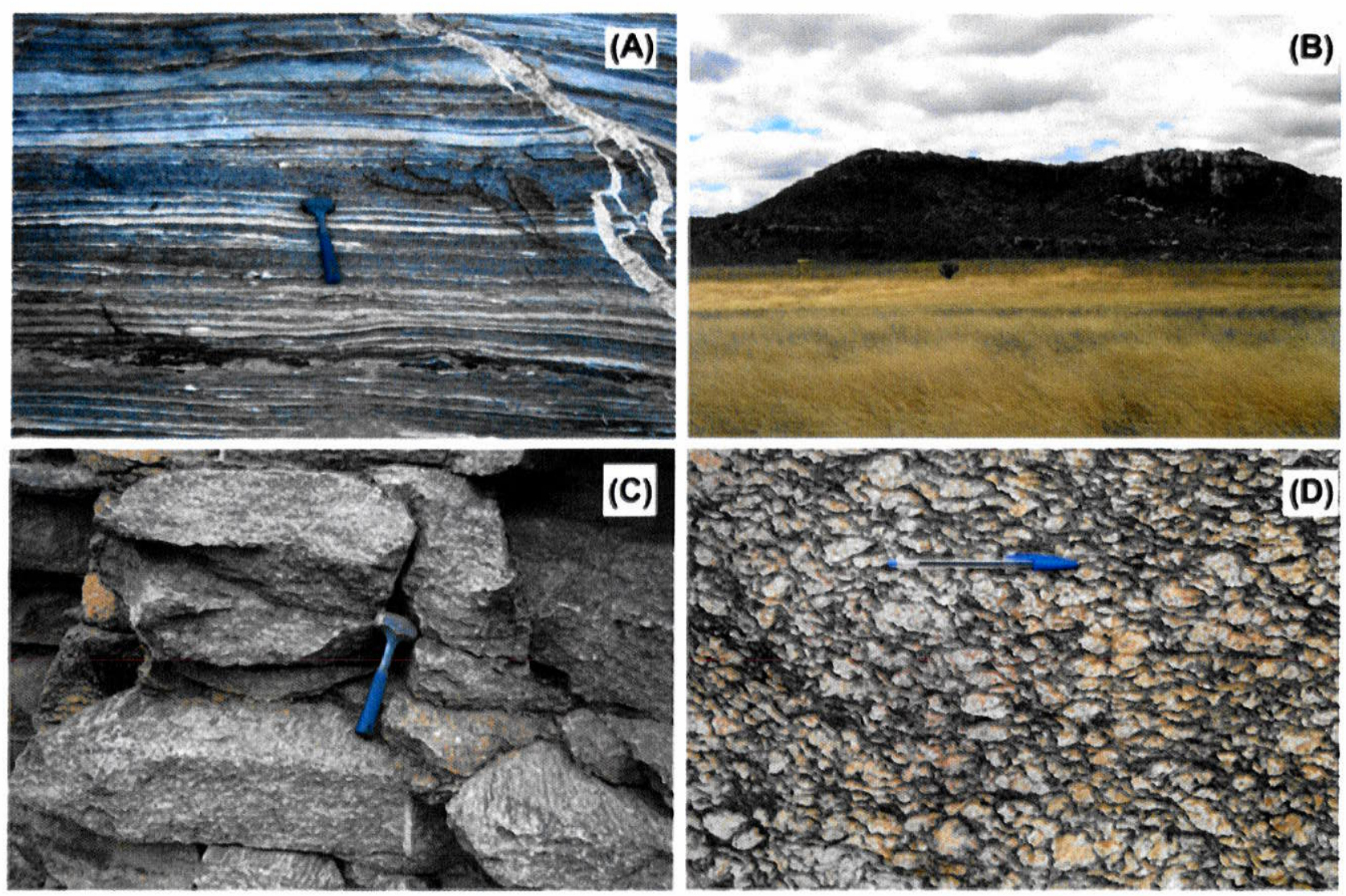

Figure 4. (A) Banded gneiss consisting of alternating felsic and mafic layers cut by pegmatitic lenses (upper right). (B) Landscape of the Santana do Matos orthogneiss (looking to the northeast) comprising a lower equigranular leucogneiss bed (arrow) dipping gently to the southeast succeeded, at the top, by an augen gneiss. The Neoproterozoic Seridó Group is stratigraphically above of these orthogneisses. (C) São Rafel augen gneiss shows a well-developed $L>S$ fabric. The lineation recorded by highly stretched feldspar porphyroclasts (visible on the surface below the hammer) plunges gently to the south. (D) Coarse augen gneiss of the Antônio Martins pluton (Corredor Farm) containing augen of feldspar that can reach up to $5 \mathrm{~cm}$ in length. The stretched feldspar and biotite flakes form a foliation that dips gently to the east.

\subsection{Results}

\subsubsection{Caicó Complex in Santa Luzia region}

Zircon grains from the banded orthogneiss of the Santa Luzia region show two different morphological types. One population is defined by elongated, oval-shaped grains around 100$150 \mu \mathrm{m}$ in length and aspect ratio (Lenght:Width) of $2: 1$, whereas the second one is characterized by small $(c .50 \mu \mathrm{m})$ rounded grains with ratio $1: 1$. Concentric and sector zoning $\mathrm{CL}$ patterns are observed in both zircon populations, some of them also presenting metamict cores. Bright overgrowths are mostly discrete and discontinuous. There is no systematic 
difference in age between the morphological types. Eighteen analyses were carried on distinct grains, two of which yielded nearly concordant but older ${ }^{207} \mathrm{~Pb} /{ }^{206} \mathrm{~Pb}$ ages (spot on grains \#1.1 and \#3.3). From the remaining sixteen analyses, eleven aligned on a discordia with upper intercept at $2400 \pm 40 \mathrm{Ma}$ (Fig. 5), which is the best estimate from the data set (spots \#4.1, \#7.1, \#9.1, \#10.1 and \#11.1 are not included). The outlier analyses (shaded points on the diagram) seems to define a poor quality discordia with upper intercept at c. $2670 \mathrm{Ma}$, which could be suggestive of inheritance from older (source?) rocks.

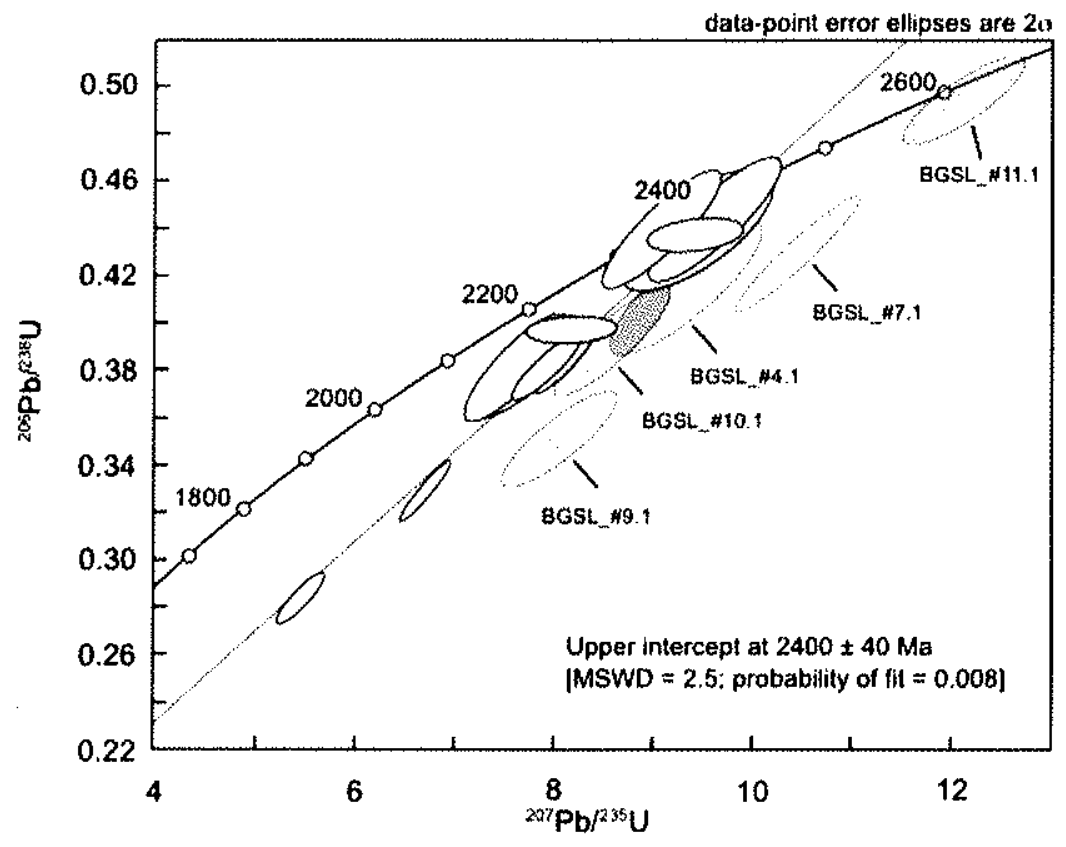

Figure 5. U-Pb concordia diagram for the banded orthogneiss of the Santa Luzia region (BGSL) with the best discordia fit for eleven analyses (white ellipses) on different grains; gray ellipses represent the not included analyses in the calculated age, but may indicate inherited zircons from an older material. Analyses \#1.1 and \#3.3 yielded very older ages and are not plotted on the diagram.

Zircons separated from Riacho Fundo metaleucogabbro are clear, mostly rounded (1:1 to $2: 1$ ) grains displaying discrete sector zoning patterns, although there exist a few elongate oscillatory-zoned grains that seems to be inherited (not analyzed). CL images show very thin and discontinuous bright overgrowths surrounding the grains, but cores and microfractures are rare or absent. Fifteen analyses on different grains align near the Concordia defining a discordia with upper intercept at $2207 \pm 35 \mathrm{Ma}$, the poor precision probably due to clustered analyses (Fig. 6). Such a discordia age is the same as the calculated weighted mean ${ }^{207} \mathrm{~Pb} /{ }^{206} \mathrm{~Pb}$ age of $2210 \pm 30 \mathrm{Ma}$, after excluding the more discordant spots \#4.1, \#6.1, \#9.1, \#13.1, \#15.1. 


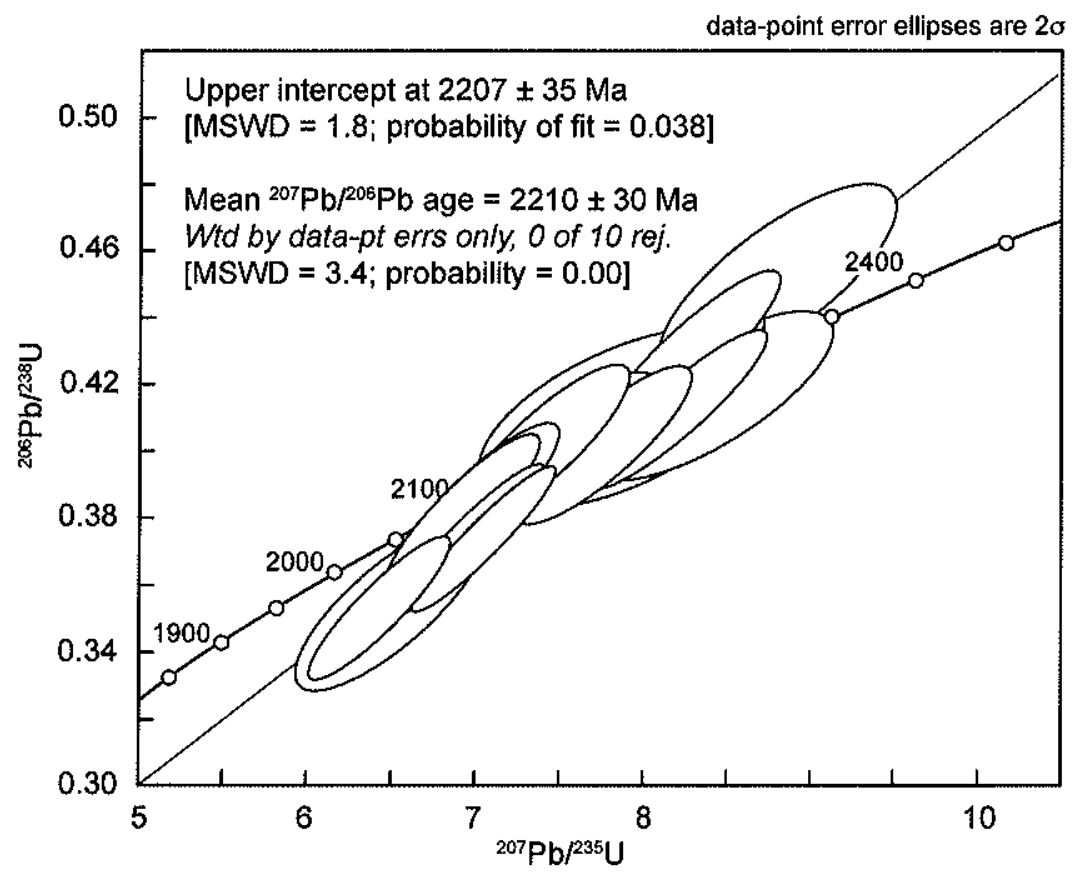

Figure 6. U-Pb concordia diagram for the Riacho Fundo metaleucogabbro (RF) showing the best discordia fit for fifteen analyses (white ellipses) on different grains.

\subsubsection{Sheeted augen and leucogneisses}

Zircons from the São Rafael pluton are euhedral to subhedral in shape, about 100-200 $\mu \mathrm{m}$ in length, and $L: W$ ratio ranging between $2: 1$ and $3: 1$. In spite of mylonitization that affects the sample, well-developed oscillatory zoning in zircons indicate they were formed in the magmatic state. Thin and discontinuous U-rich overgrowths and cores from which microfractures radiate are found in some grains. Analyses on thirteen zircons are quite discordant. The best discordia fit is estimated from eleven analyses (excluding \#3.1 and \#9.1) yielding an upper intercept age at $2236 \pm 80 \mathrm{Ma}$ (Fig. 7).

Zircons from the São José do Seridó sample are euhedral to subhedral with about 100 $\mu \mathrm{m}$ in length and $\mathrm{L}: W$ ratio about $2: 1$. The grains are generally fractured and show no inherited cores. Analyses on the oscillatory zoning domains give variable $U$ contents usually between 100 and $550 \mathrm{ppm}$. Thin U-rich overgrowths are also present. Thirteen from the eighteen analyzed zircons align on a discordia with upper intercept at $2248 \pm 18 \mathrm{Ma}$ (Fig. 8; after excluding the discordant analyses \#4.1, \#9.1, \#10.1, \#12.1 and \#13.1), which is consistent with the calculated weighted mean ${ }^{207} \mathrm{~Pb} /{ }^{206} \mathrm{~Pb}$ age of $2247 \pm 12 \mathrm{Ma}$ for the same analytical set. 

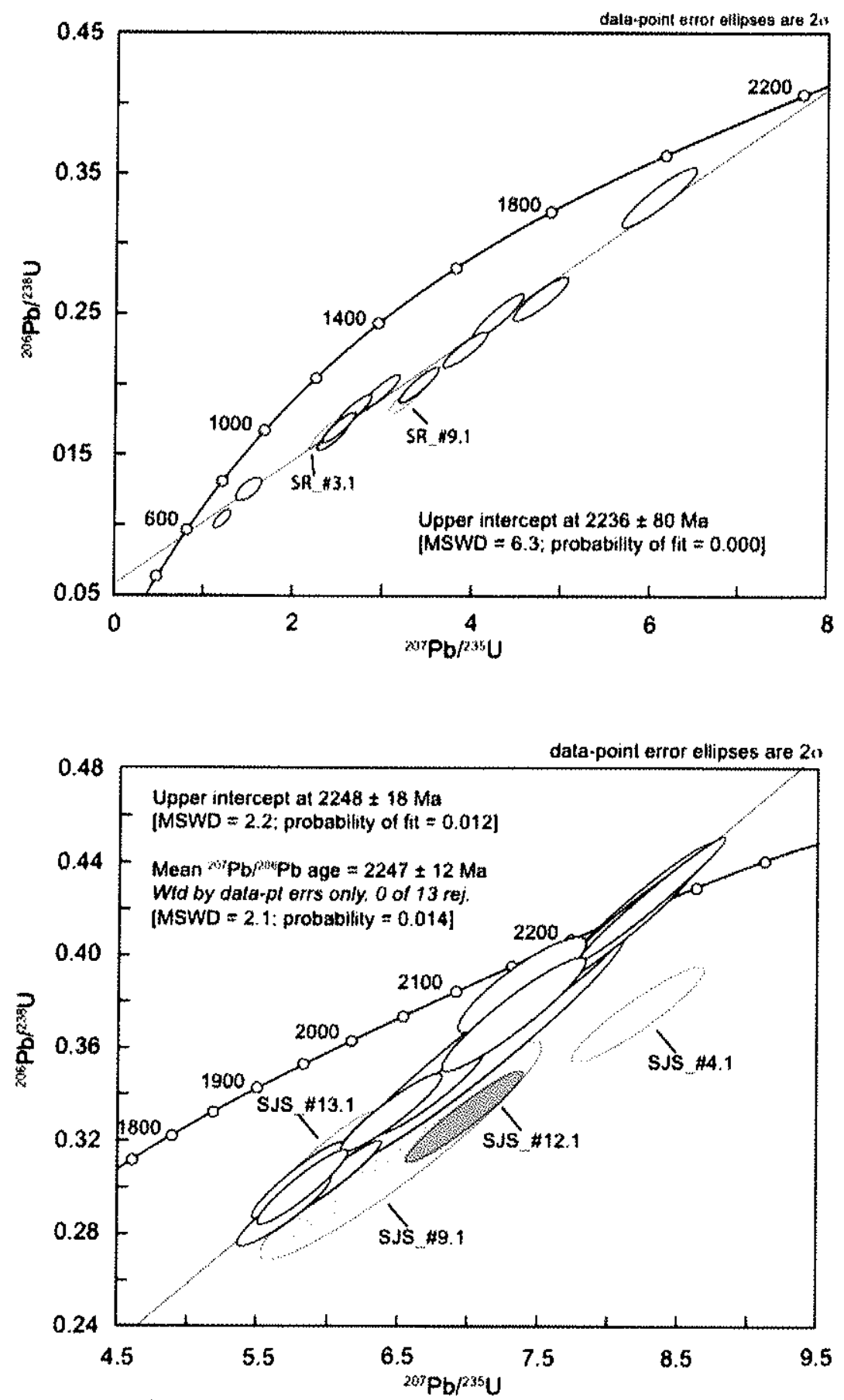

Figure 7. U-Pb concordia diagram for the São Rafael augen gneiss (SR) showing the best fit between discordant eleven analyses (white ellipses) on different grains; gray ellipses represent the outlier analyses as indicated.

Figure 8. U-Pb concordia diagram for the São José do Seridó augen gneiss (SJS). The best discordia included thirteen analyses (white ellipses) on different grains; gray ellipses represent the outlier analyses as indicated. Analysis \#10.1 iyielded a very discordant age and was not plotted on the diagram.

Zircons from Santana do Matos pluton come from an augen gneiss and a equigranular leucogneiss. Zircons from these samples are euhedral to subhedral and show indistinct oscillatory zoning. Some grains show crosscutting relations between different zoning domains as well partial reabsorbed areas given by embayment and patchy zoning. Zircons from the augen gneiss (sample SM-3) are variable in size (100-250 $\mu \mathrm{m}$ in length) displaying short prismatic habit (L:W between $1: 1$ and 2:1), sometimes with slightly rounded ends. Zircons from the leucogneiss (SM-4) are euhedral reaching up to $200 \mu \mathrm{m}$ in length. Upper intercept U-Pb ages from each sample (not graphically shown) were individually defined using all analytical data at $2270 \pm 24 \mathrm{Ma}$ for the augen gneiss and $2227 \pm 15 \mathrm{Ma}$ for the leucogneiss. The data for 
the two samples yield an upper intercept age at $2208 \pm 13 \mathrm{Ma}$ (Fig. 9) not considering two very discordant analyses (SM-4 \#2.3 and SM-4 \#10.2), which is quite similar to its weighted mean ${ }^{207} \mathrm{~Pb} /{ }^{206} \mathrm{~Pb}$ age at $2213.6 \pm 8.7 \mathrm{Ma}$ (after removing the younger analyses $\mathrm{SM}-3 \# 5.1, \mathrm{SM}-3 \# 9.1$ and SM-4 \#10.2).

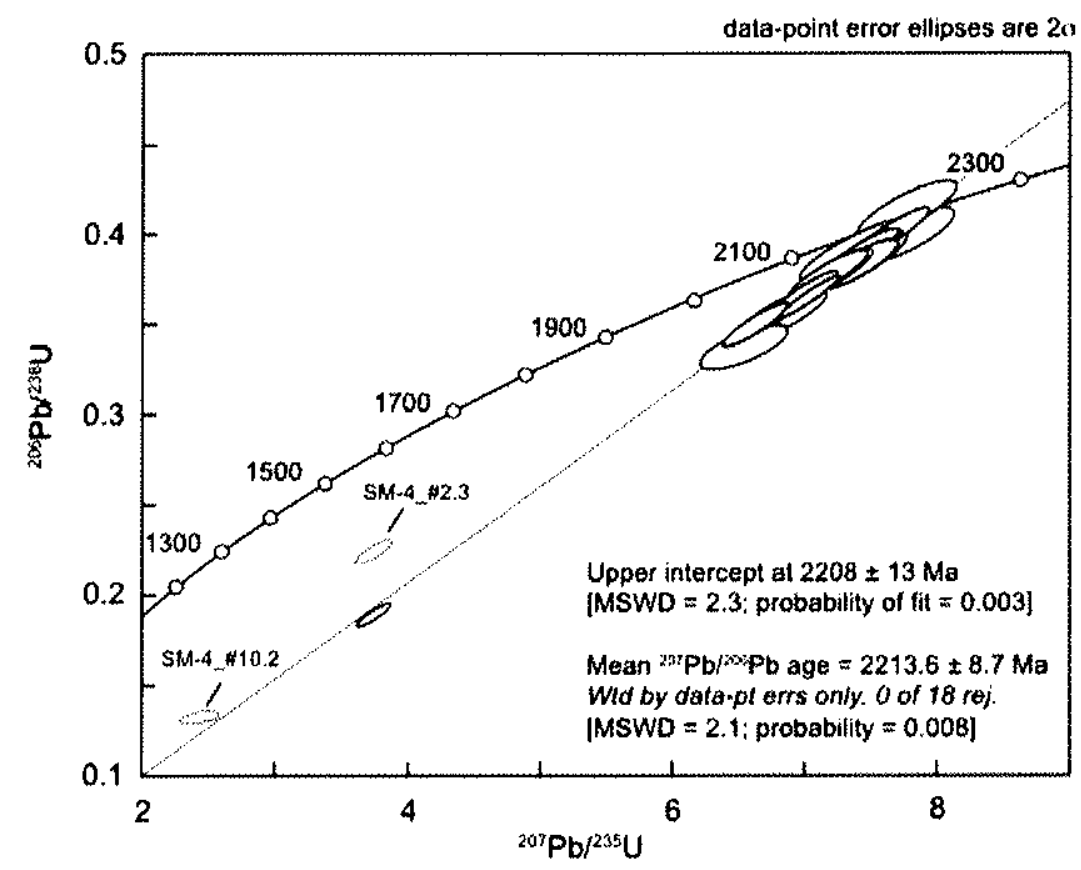

Figure 9. U-Pb concordia diagram for the Santana do Matos augen and leucogneiss (SM). The best discordia was built with eighteen analyses (white ellipses) on different grains; gray ellipses represent the outlier analyses as indicated.

\subsubsection{The batholitic plutons}

Zircons from the Antônio Martins sample are euhedral to subhedral with length reaching up to $200 \mu \mathrm{m}$ and L:W ratio ranging between $2: 1$ and 4:1. Grains are clear, often fractured, and show weak to moderate concentric compositional zoning. Strongly metamitized cores were observed in some zircons. All thirteen analysis carried out on different grains define a discordia line with upper intercept at $2172 \pm 24 \mathrm{Ma}$ (Fig. 10), which is similar to the calculated weighted mean ${ }^{207} \mathrm{~Pb} /{ }^{206} \mathrm{~Pb}$ age of $2169 \pm 20 \mathrm{Ma}$.

The Serra Negra sample yielded clear, euhedral to subhedral zircons reaching up to 200 $\mu \mathrm{m}$ and $\mathrm{L}: W$ ratio between $2: 1$ and $3: 1$. Concentric compositional zoning varies from broad, poorly defined in some grains to more strongly zoned domains in others. CL images show unequivocally bright patchs and rims. Some rims show a poor content in Th that are attributed to a metamorphic overgrowth (analyses \#2.1, \#5.2, \#6.2 and \#12.2). Cores can be present (e.g., analysis \#9.1). Twelve analyses spotted on the concentric zoning plot as a group near the concordia with an weighted mean ${ }^{207} \mathrm{~Pb} /{ }^{206} \mathrm{~Pb}$ age of $1741.4 \pm 8.8 \mathrm{Ma}$, which is similar to the upper intercept at $1741.9 \pm 9.6 \mathrm{Ma}$ (insert in Fig. 11). 

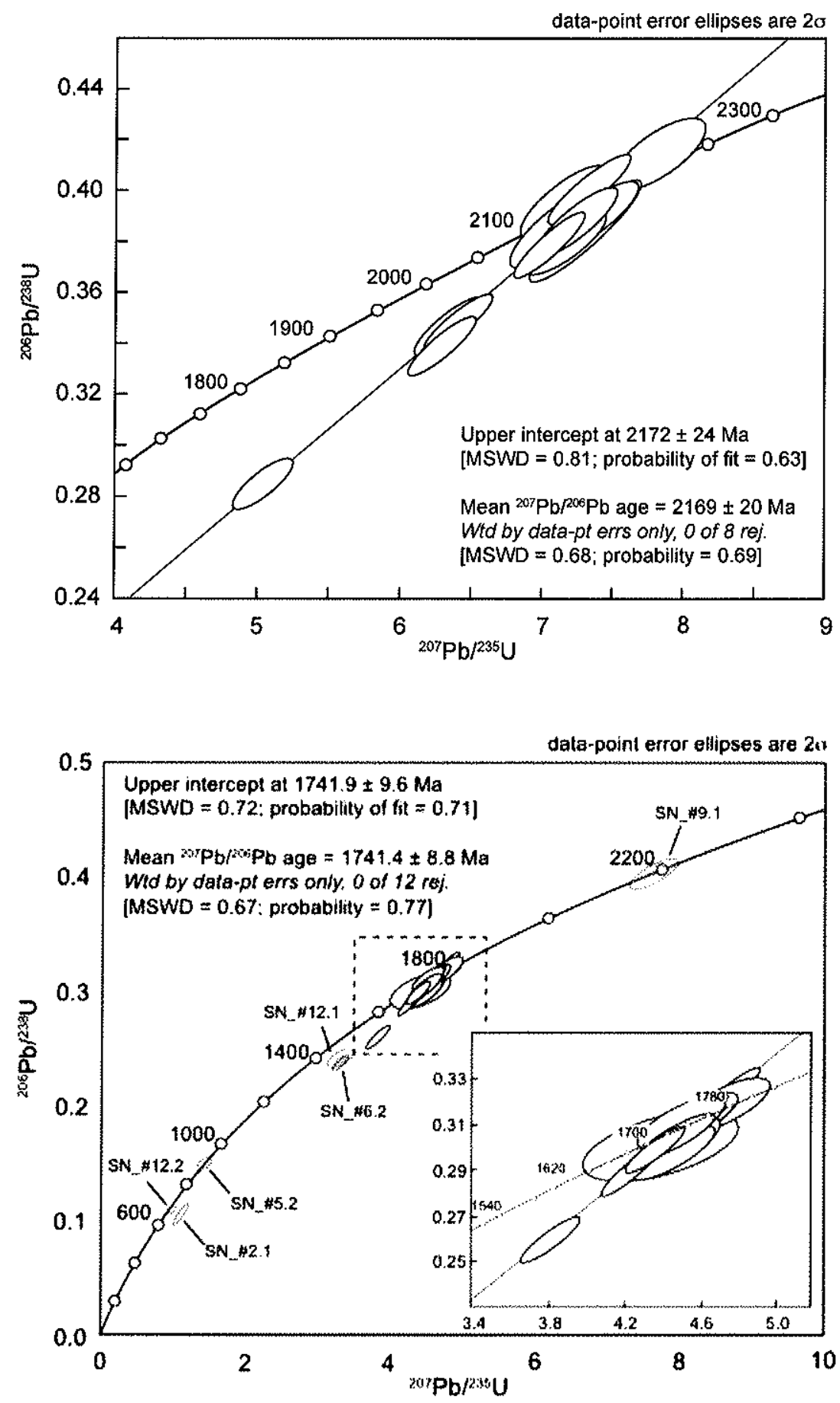

Figure 10. U-Pb concordia diagram for the Antonio Martins augen gneiss (AM) showing a discordia including thirteen analyses (white ellipses) on different grains.
Figure 11. U-Pb concordia diagram for the Serra Negra augen gneiss (SN) including all analyses. The best discordia fit is given by twelve analyses (white ellipses) on different grains; gray ellipses represent the outlier analyses as indicated. Except analysis \#9.1 that was carried out on an older grain, all outlier analyses where taken on U-rich rims.

\section{Sm-Nd ISOTOPE DATA}

We determined the Sm-Nd data for each sample studied by U-Pb geochronology. Two additional samples of augen gneiss (Jardim de Piranhas, JP) and leucogneiss (Serra das Pinturas, SP) for which U-Pb dating are not available were included and all results are listed in Table 2.

Approximately $60-80 \mathrm{mg}$ of powdered rock samples were dissolved in successive acid attacks with concentrated $\mathrm{HF}, \mathrm{HNO}_{3}$ and $\mathrm{HCl}$ at $100^{\circ} \mathrm{C}$. Sm and $\mathrm{Nd}$ were separated from the 
whole rock by conventional ion-exchange chromatography routines using RE-Spec and LNSpec resins. Their concentrations were determined by isotope dilution using a mixed ${ }^{149} \mathrm{Sm}$ -

${ }^{150} \mathrm{Nd}$ tracer (1:1) and measured by thermal ionization mass spectrometry. Sm was measured in single collection mode on a monocollector VG-354® after loading on a single Re-filament, whereas $\mathrm{Nd}$ was loaded on a double Re-filament assembly and measured in static mode in a multicollector mass spectrometer Finnigan MAT $262 \AA$ ( 7 Faraday cup collectors). All measurements were carried out at the Geochronological Research Center (São Paulo, Brazil). Details for analytical procedures and measurements are also given in Table 2.

Initial $\mathrm{Nd}$ isotopic compositions for all samples were calculated to their respective U-Pb ages (see Table 1). For the JP and SP samples the initial ${ }^{143} \mathrm{Nd} /{ }^{144} \mathrm{Nd}$ ratios were calculated assuming an average age of $2.2 \mathrm{Ga}$. Most results groups in a narrow range of isotopic compositions between 0.511023 and 0.511167 combined with typical continental crust ${ }^{147} \mathrm{Sm} /{ }^{144} \mathrm{Nd}$ ratios between 0.0906 and 0.1004 . Their initial $\mathrm{Sm}$ and $\mathrm{Nd}$ ratios define moderately negative eNd values around -1.9 and -3.9. Exceptions are the $1.75 \mathrm{Ga}$ old Serra Negra augen gneiss that presents more negative initial $\varepsilon N d$ of -6.9 , and the banded orthogneiss of the Santa Luzia region with $\varepsilon \mathrm{Nd}_{(2.4 \mathrm{Ga})}$ equal to -0.4 . $\mathrm{Nd}$ model ages $\left(t_{\mathrm{DM}}\right)$ range from 2.5 to $2.8 \mathrm{Ga}$. The SM-3 augen gneiss and RF metaleucogabbro, however, yielded older $\mathrm{Nd}$ model ages as result of fractionation of $\mathrm{Sm}$ relative to $\mathrm{Nd}$ as suggested by ${ }^{147} \mathrm{Sm} /{ }^{144} \mathrm{Nd}$ ratios higher $(>0.13)$ than the average values for continental crust $(<0.12)$.

\section{DISCUSSION}

Our U-Pb SHRIMP zircon ages attest to the long-lived Paleoproterozoic magmatic history in the basement complex of the Seridó-Jaguaribe domain. In spite of the discordant behavior of most analyses, the ages obtained on the igneous zoning areas yielded three major periods of magmatic emplacement, i.e., at c. $2.4 \mathrm{Ga}, 2.2 \mathrm{Ga}$ and $1.75 \mathrm{Ga}$. Discordance of the U$\mathrm{P}, \mathrm{b}$ system can be attributed to variable $\mathrm{Pb}$ loss in the crystal structure due to metamictization followed by recoil during later thermal event. This is particularly pronounced when the time elapsed since the crystallization until thermal disturbance is long enough for zircon to become metamict, and temperature is about (or even below) amphibolite facies conditions $\left(600-650^{\circ} \mathrm{C}\right.$ ) in order to leach $\mathrm{Pb}$ from metamicted areas rather than recrystallization (e.g., Mezger and Krogstad, 1997). Large areas of the Seridó-Jaguaribe domain were metamorphosed in amphibolite facies, in which it is quite common to find migmatites among the basement rocks. Some studies consider that the migmatization is a Paleoproterozoic high-grade metamorphism (see Souza et al., 2008, and references therein), but there are growing evidences in NE Brazil and in Africa that at least part of the basement complex melted or reached the granulite facies 
only in the Brasiliano-Pan African orogen (Pin and Poidevin, 1987; Corsini et al., 1991). In spite of disturbance, the regressions of the U-Pb SHRIMP data are all well defined and usually include concordant (or semi-concordant) analyses, giving reliable upper intercept ages. The lower intercepts, however, have no geological significance since they are always younger than $500 \mathrm{Ma}$. When examining CL images we see only thin to absent rims or overgrowths or, locally, a faint recrystallization over the grain border that usually is not large enough to be precisely dated, even using in situ techniques. Some larger U-rich zircon rims were tentatively analyzed in the Serra Negra augen gneiss. They give ${ }^{207} \mathrm{~Pb} /{ }^{206} \mathrm{~Pb}$ ages of $814 \mathrm{Ma}$ and $926 \mathrm{Ma}$ with no geological significance, but indicate that the recrystallized rim is a younger feature probably formed in the Neoproterozoic.

The older zircons of our study come from a biotite-amphibole metagranodiorite corresponding to the felsic layer of a banded gneiss of the Santa Luzia region. Although the age shows a relatively high analytical error, the upper intercept provides an U-Pb age at $2400 \pm 40$ $\mathrm{Ga}$. The sequence of banded gneiss, kinzingite, lenses of marble and calc-silicate gneiss of Santa Luzia constitute a supracrustal unit which has been associated with the c. 2.2 Ga Caicó Complex (e.g., Souza et al., 2008). However, even if we consider the analytical error of the zircon ages from the metagranodiorite, the Santa Luzia supracrustals are older than the Caicó Complex. Hence, we consider the Santa Luzia supracrustals a rock sequence distinct of the Caicó Complex. This conclusion is supported by the dating of a metaleucogabbro (G2-RF sample) sheet intrusive into the banded gneiss that yields an U-Pb age of $2207 \pm 35 \mathrm{Ma}$. Another supracrustal sequence consisting of hornblende-biotite tonalite gneiss, calc-silicate gneiss and banded iron formation intercalated with amphibolite has been described in Lajes region situated to the north of Santa Luzia region (see Figs. 2 and 3). There, zircons from a tonalitic orthogneiss provided an U-Pb age at c. 2.33 Ga (LA-MC-ICPMS; Dantas et al., 2008). $\mathrm{Nd}$ parameters for the banded gneiss of Santa Luzia include $t_{\mathrm{DM}}$ model age of $2.6 \mathrm{Ga}$ and initial $\varepsilon \mathrm{Nd}(2.4)$ value slightly negative $(-0.4)$, which is consistent with the $\mathrm{Sm}-\mathrm{Nd}$ data reported for the Lajes supracrustal rocks. Crustal fragments in the range of $2.4-2.3 \mathrm{Ga}$ have also been described in the Ceará state, at the NW sector of the Borborema Province (Fetter et al., 2000) suggesting that the whole domain to the north of the Patos shear zone would constitute a single crustal block. However, the geological context for generation of these rock sequences is not yet fully understood.

The most important Paleoproterozic magmatic activity of the Seridó-Jaguaribe domain is undoubtedly situated in the Rhyacian. These orthogneisses are collectively named "metaplutonics of the Caicó Complex" and include rocks with compositions varying from granite, granodiorite to tonalite and diorite. A particular type of granitic gneisses (the G2-type studied in this work) was considered syntectonic to an orogenic event at c. $2.0 \mathrm{Ga}$ (Bertrand and Jardim de Sá, 1990; Jardim de Sá et al., 1995). However, two G2-type augen gneisses (Santana do 
Matos and São José do Seridó) provided well-constrained upper intercept zircon ages at $2248 \pm$ $18 \mathrm{Ma}$ and $2208 \pm 13 \mathrm{Ma}$. Furthermore, a pluton of batholithic dimension also described as G2type augen gneiss (Antônio Martins) provided a discordia age with upper intercept at $2172 \pm 24$ Ma. In contrast, very discordant zircons characterize the mylonitic augen gneiss of São Rafael, and eleven zircons aligned below the concordia yield an upper intercept at $2236 \pm 80 \mathrm{Ma}$. Such an age agrees with those of the Santana do Matos and São José do Seridó augen gneisses and, in turn, must corresponds to the magmatic crystallization of the São Rafael granite. Legrand et al. (1991) using conventional U-Pb (TIMS) also found highly discordant zircon fractions in the São Rafael augen gneiss. Three fractions plotted near the lower intercept and aligned to give an upper intercept age at $1.95 \mathrm{Ga}$. This age has long been considered an evidence for a regional Transamazonian tectonothermal event in the Seridó belt (Jardim de Sá et al., 1995). It was contested by Archanjo and Legrand (1997), which argued for the low reliability of the data, with the upper intercept probably corresponding to a minimum age. Actually, the results obtained from our U-Pb SHRIMP data from the G2-type augen gneisses indicate that there is no evidence for a metamorphic event about $2.0 \mathrm{Ga}$ in the Seridó-Jaguaribe domain or, alternatively, this event should be quite weak to be largely overprinted by the Brasiliano-Pan African fabric. Further geochronological studies, however, are needed to fully corroborate this assessment.

$\mathrm{Nd}$ isotopic signatures for the Rhyacian augen gneisses are shown in Figure 12. Depleted mantle model ages range between c. 2.5-2.8 Ga and are about 200-500 Ma older than the best protolith age estimates based on our U-Pb zircon data. This, together with negative (and variable) initial $\varepsilon \mathrm{Nd}$ values and typically crustal $\mathrm{Sm}-\mathrm{Nd}$ ratios, is suggestive of either different degree of interaction with (or recycling of) an older, probably Neoarchean, continental material in their genesis, derivation from an enriched lithospheric mantle source, or even a combination of both. In fact, remnants of Archean crust are still preserved in the eastern part of the Seridó-Jaguaribe domain (Dantas et al., 2004).

The third magmatic activity occurred in the Late Paleoproterozoic, at Statherian period, until now just described in the Orós, Jaguaribe and Serra de São José belts. The Orós belt, the best studied unit, consists mainly of siliciclastic and chemical sediments alternating with volcanic rocks deposited in a rift environment (Parente et al., 2004). U-Pb zircon ages of associated alkaline granites (now augen gneiss) and acid metavolcanics group in the interval of $1.75-1.80 \mathrm{Ga}$ (Sá et al., 1995). Previous tectonic models argued that Late Paleoproterozoic rift settting would be restricted to the Jaguaribe domain and a crustal suture should be searched for just to the west of the Serra de São José belt (e.g. Arthaud et al., 2008). Neverthless, the Serra Negra pluton, previously described as G2-type augen gneiss, shows that the Late Proterozoic magmatism also reached the Seridó Belt. Nearly concordant zircons defined a precise U-Pb age of $1741.9 \pm 9.6 \mathrm{Ma}$, which is attributed to the crystallization of that pluton. In addition it 
includes a gently dipping penetrative foliation that can be followed in continuity within the host gneisses of the Caicó Complex to show that the regional tangential fabric must to be formed in the Neoproterozoic. Late Paleoproterozoic sub-alkaline orthogneisses emplaced in metasiliciclastic rocks of c. $1.85 \mathrm{Ga}$ (U-Pb zircon age) were described in SW Nigeria (Rahaman, 1988) and correlated with the Orós belt (Arthaud et al., 2008), as well as metavolcanic rocks apparently associated with (meta)psamite-pelite and carbonate rocks described in NW Borborema (Médio Coreaú domain) were recently dated in c. $1.78 \mathrm{Ga}$ (U-Pb zircon age; Santos et al., 2008). All these intraplate petrogenetic associations appear to be formed during a wide extensional event between 1.85 and $1.75 \mathrm{Ga}$, possibly recording a failed continental breakup succeeding an important crustal accretion at c. $2.2 \mathrm{Ga}$.

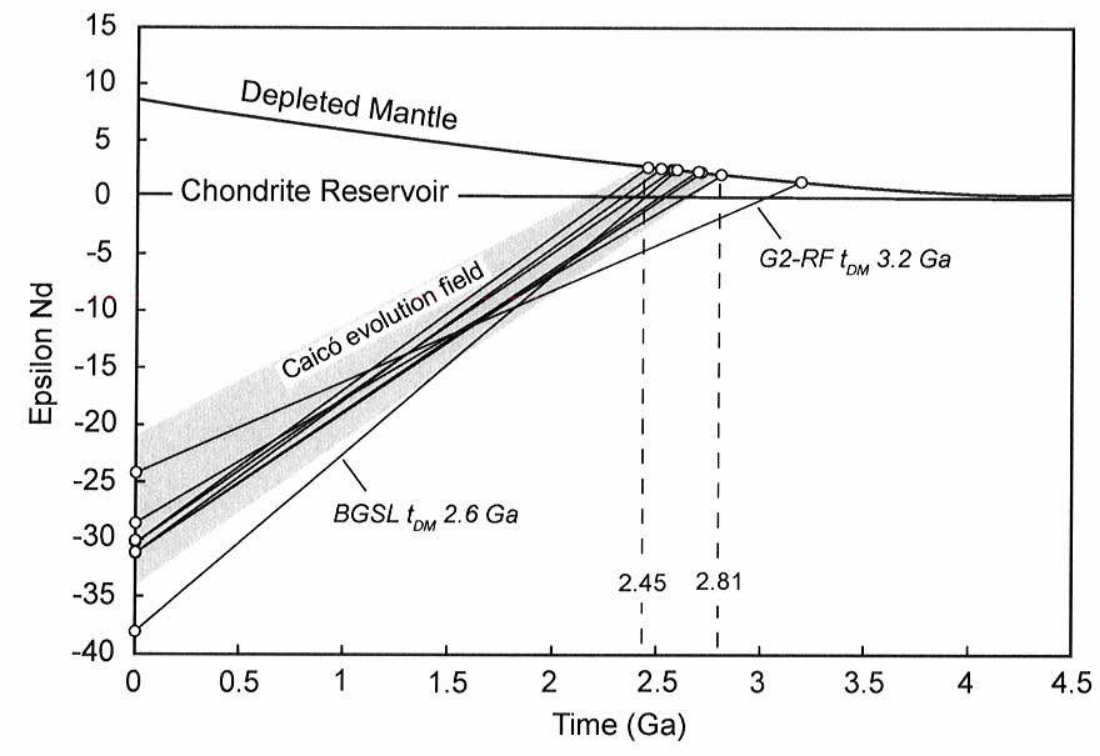

Figure 12. Time-related $\mathrm{Nd}$ evolution diagram for the augen and leucogneisses. Data for the SM-3 sample is not showed in the diagram due its strong fractionated behavior. Nd evolution field for gneisses and migmatites from the Caicó complex is shown for comparison (data from Dantas, 1997, Hollanda et al., 2003 and Souza et al., 2008).

\section{CONCLUSION}

New zircon U-Pb (SHRIMP) and Sm-Nd data on augen gneiss previously considered syntectonic magmas of an orogenic event at c. $2.0 \mathrm{Ga}$ ("Transamazonian") show that they are isotopically indistinguishable from the Caicó basement dated at $2.15-2.20 \mathrm{Ga}$. The studied zircons are usually discordant but for the São José do Seridó, Santana do Matos and Antônio Martins plutons they define well-constrained upper intercept crystallization ages at, respectively, 2.25, 2.21 and $2.17 \mathrm{Ga}$ (MSWD between 0.8 and 2.2, and error estimates lower than $0.02 \mathrm{Ga}$ ). A similar age was obtained for a metaleucogabbro sheet $(c .2 .21 \mathrm{Ga}$ ) intrusive in the older, Santa Luzia supracrustal sequence (banded gneisses, kinzigites and marbles) now dated at $2.40 \mathrm{Ga}$ that, in turn, could be invoked as the host regional rocks for the emplacement of the augen gneisses. The coarse porphyritic granite pluton (now a coarse augen gneiss) of Serra Negra gives an unexpected, nearly concordant, U-Pb age of $1.74 \mathrm{Ga}$ indicating that the 
magmatic activity of the basement complex extended to the Late Paleoproterozoic. Our results, therefore, allow definition of an important magmatic activity in the Seridó-Jaguaribe domain in the Borborema Province at c. $2.2 \mathrm{Ga}$ (Rhyacian), probably representing continental accretion involving mostly recycling of older crust, and again in the Statherian period, corresponding to continental break-up and rifting.

\section{Acknowledgements}

This study was supported by Pro-Reitoria de Pesquisa (Projeto 1) of the University of São Paulo. M.H.B.M.H. thanks to Emanuel Jardim de Sá for introducing the geology of the Seridó augen gneisses, specially the Serra Negra pluton. 


\begin{tabular}{|c|c|c|c|c|c|c|c|c|c|c|c|c|c|c|c|c|c|}
\hline \multirow{2}{*}{$\begin{array}{r}\begin{array}{r}\text { Grain } \\
\text { spot \# }\end{array} \\
\text { Santa Luz }\end{array}$} & \multirow{2}{*}{$\begin{array}{c}\% \\
{ }^{206} \mathrm{~Pb}_{\mathrm{c}} \\
\text { banded }\end{array}$} & \multirow{2}{*}{$\begin{array}{c}\begin{array}{c}U \\
\text { [ppm] }\end{array} \\
\text { orthogne }\end{array}$} & \multirow{2}{*}{$\begin{array}{c}\begin{array}{c}\text { Th } \\
\text { [ppm] }\end{array} \\
\text { iss }\end{array}$} & \multirow[t]{2}{*}{${ }^{232} \mathrm{Th} /{ }^{238} \mathrm{U}$} & \multirow[t]{2}{*}{$\begin{array}{l}{ }^{206} \mathrm{~Pb}^{*} \\
{[\mathrm{ppm}]}\end{array}$} & \multicolumn{2}{|c|}{$\begin{array}{c}{ }^{206} \mathrm{~Pb} / /^{238} \mathrm{U} \\
\text { age }\end{array}$} & \multicolumn{2}{|c|}{$\begin{array}{c}{ }^{207} \mathrm{~Pb} /{ }^{206} \mathrm{~Pb} \\
\text { age }\end{array}$} & \multirow[t]{2}{*}{$\%$ disc } & \multirow[t]{2}{*}{${ }^{207} \mathrm{~Pb}^{\star}{ }^{\star 206} \mathrm{~Pb}^{\star}$} & \multirow[t]{2}{*}{ $\pm \%$} & \multirow[t]{2}{*}{${ }^{207} \mathrm{~Pb}^{\star} /{ }^{235} \mathrm{U}$} & \multirow[t]{2}{*}{ $\pm \%$} & \multirow[t]{2}{*}{$\left.{ }^{206} \mathrm{~Pb}^{\star}\right|^{238} \mathrm{U}$} & \multirow[t]{2}{*}{ $\pm \%$} & \multirow[t]{2}{*}{ err corr } \\
\hline & & & & & & & & & & & & & & & & & \\
\hline 1.1 & 0.24 & 195 & 154 & 0.81 & 102 & 3053 & \pm 17 & 3248.9 & \pm 7.3 & 6 & 0.2604 & 0.47 & 21.75 & 0.83 & 0.6058 & 0.69 & .828 \\
\hline 2.1 & 0.35 & 223 & 306 & 1.42 & 84.2 & 2338 & \pm 14 & 2415 & \pm 33 & 3 & 0.1562 & 1.9 & 9.42 & 2.0 & 0.4372 & 0.71 & .348 \\
\hline 3.1 & 0.61 & 226 & 170 & 0.78 & 77.6 & 2157 & \pm 12 & 2333 & \pm 37 & 8 & 0.1488 & 2.2 & 8.16 & 2.3 & 0.3975 & 0.64 & .283 \\
\hline 3.3 & 0.97 & 114 & 54 & 0.49 & 53.7 & 2804 & \pm 20 & 2722 & \pm 19 & -3 & 0.1877 & 1.1 & 14.10 & 1.4 & 0.5449 & 0.89 & .620 \\
\hline 4.1 & 0.86 & 46 & 69 & 1.55 & 16.4 & 2236 & \pm 54 & 2491 & \pm 31 & 10 & 0.1633 & 1.9 & 9.34 & 3.4 & 0.415 & 2.8 & .838 \\
\hline 5.1 & 2.26 & 102 & 104 & 1.05 & 39.3 & 2345 & \pm 48 & 2413 & \pm 39 & 3 & 0.1560 & 2.3 & 9.43 & 3.4 & 0.439 & 2.5 & .734 \\
\hline 5.2 & 1.14 & 88 & 94 & 1.10 & 34.1 & 2367 & \pm 49 & 2423 & \pm 24 & 2 & 0.1569 & 1.4 & 9.60 & 2.9 & 0.444 & 2.5 & .866 \\
\hline 6.1 & 1.12 & 162 & 89 & 0.56 & 62.0 & 2348 & \pm 47 & 2345 & \pm 23 & 0 & 0.1499 & 1.3 & 9.08 & 2.7 & 0.439 & 2.4 & .875 \\
\hline 7.1 & 0.68 & 312 & 306 & 1.01 & 116 & 2305 & \pm 46 & 2619 & \pm 12 & 12 & 0.1763 & 0.70 & 10.45 & 2.5 & 0.430 & 2.4 & .959 \\
\hline 8.1 & 0.94 & 131 & 40 & 0.31 & 43.4 & 2080 & \pm 43 & 2313 & \pm 28 & 10 & 0.1471 & 1.6 & 7.73 & 2.9 & 0.3808 & 2.4 & .834 \\
\hline 9.1 & 1.19 & 156 & 42 & 0.28 & 47.6 & 1941 & \pm 41 & 2520 & \pm 26 & 23 & 0.1662 & 1.6 & 8.05 & 2.9 & 0.3513 & 2.4 & .842 \\
\hline 10.1 & 0.66 & 175 & 57 & 0.34 & 59.5 & 2136 & \pm 44 & 2439 & \pm 23 & 12 & 0.1584 & 1.4 & 8.58 & 2.8 & 0.3929 & 2.4 & .866 \\
\hline 11.1 & 2.23 & 73 & 26 & 0.36 & 31.4 & 2555 & \pm 54 & 2653 & \pm 33 & 4 & 0.1800 & 2.0 & 12.07 & 3.2 & 0.486 & 2.5 & .785 \\
\hline 12.1 & 1.32 & 138 & 90 & 0.67 & 46.0 & 2088 & \pm 44 & 2280 & \pm 24 & 8 & 0.1444 & 1.4 & 7.61 & 2.8 & 0.3824 & 2.4 & .871 \\
\hline \multicolumn{18}{|c|}{ Riacho Fundo (RF) augen gneiss } \\
\hline 1.1 & 2.88 & 42 & 22 & 0.54 & 15.4 & 2219 & \pm 50 & 2211 & \pm 62 & 0 & 0.1642 & 1.8 & 7.86 & 4.4 & 0.411 & 2.7 & .601 \\
\hline 2.1 & 0.65 & 164 & 63 & 0.40 & 58.6 & 2230 & \pm 45 & 2272 & \pm 17 & 2 & 0.14946 & 0.66 & 8.19 & 2.6 & 0.4134 & 2.4 & .927 \\
\hline 3.1 & 0.88 & 129 & 45 & 0.36 & 48.4 & 2314 & \pm 48 & 2213 & \pm 21 & -5 & 0.1466 & 0.80 & 8.26 & 2.7 & 0.432 & 2.4 & .897 \\
\hline 4.1 & 0.89 & 170 & 58 & 0.35 & 52.2 & 1957 & \pm 48 & 2133 & \pm 38 & 8 & 0.1405 & 1.8 & 6.49 & 3.6 & 0.355 & 2.9 & .797 \\
\hline 5.1 & 1.05 & 134 & 37 & 0.29 & 46.6 & 2171 & \pm 45 & 2180 & \pm 33 & 0 & 0.1455 & 1.3 & 7.52 & 3.1 & 0.4004 & 2.4 & .788 \\
\hline 6.1 & 0.43 & 116 & 30 & 0.27 & 35.5 & 1954 & \pm 41 & 2120 & \pm 20 & 8 & 0.1354 & 0.84 & 6.43 & 2.7 & 0.3541 & 2.4 & .904 \\
\hline 7.1 & 0.43 & 248 & 49 & 0.20 & 80.1 & 2050 & \pm 42 & 2183 & \pm 14 & 6 & 0.14024 & 0.62 & 7.04 & 2.5 & 0.3743 & 2.4 & .948 \\
\hline 8.1 & 0.80 & 102 & 30 & 0.30 & 36.8 & 2250 & \pm 46 & 2228 & \pm 29 & -1 & 0.1472 & 0.82 & 8.07 & 3.0 & 0.418 & 2.4 & .823 \\
\hline 9.1 & 0.57 & 176 & 62 & 0.37 & 61.1 & 2181 & \pm 44 & 2143 & \pm 26 & -2 & 0.1384 & 1.2 & 7.40 & 2.8 & 0.4026 & 2.4 & .849 \\
\hline 10.1 & 1.18 & 62 & 9 & 0.16 & 24.5 & 2417 & \pm 51 & 2230 & \pm 37 & -8 & 0.1507 & 1.0 & 8.80 & 3.3 & 0.455 & 2.5 & .760 \\
\hline 11.1 & 0.29 & 214 & 66 & 0.32 & 74.1 & 2181 & \pm 44 & 2224 & \pm 25 & 2 & 0.1424 & 1.3 & 7.76 & 2.8 & 0.4026 & 2.4 & .855 \\
\hline 12.1 & 0.55 & 172 & 51 & 0.31 & 55.7 & 2051 & \pm 42 & 2162 & \pm 17 & 5 & 0.1397 & 0.72 & 6.96 & 2.6 & 0.3746 & 2.4 & .925 \\
\hline 13.1 & 0.66 & 103 & 74 & 0.74 & 34.2 & 2089 & \pm 43 & 2112 & \pm 22 & 1 & 0.1369 & 0.89 & 6.91 & 2.7 & 0.3826 & 2.4 & .890 \\
\hline 14.1 & 0.80 & 132 & 44 & 0.34 & 47.7 & 2256 & \pm 46 & 2290 & \pm 44 & 1 & 0.1522 & 2.3 & 8.39 & 3.5 & 0.419 & 2.4 & .686 \\
\hline 15.1 & 0.81 & 158 & 46 & 0.30 & 52.9 & 2102 & \pm 43 & 2124 & \pm 26 & 1 & 0.1391 & 1.1 & 7.01 & 2.8 & 0.3856 & 2.4 & .854 \\
\hline \multicolumn{18}{|c|}{ São Rafael (SR) augen gneiss } \\
\hline 1.1 & 0.68 & 807 & 425 & 0.54 & 74.4 & 652.6 & 14.4 & 1238 & \pm 43 & 47 & 0.0817 & 2.2 & 1.20 & 3.2 & .1065 & 2.3 & .725 \\
\hline 2.1 & 0.18 & 428 & 258 & 0.62 & 74.1 & 1181.1 & 26.5 & 1993 & \pm 20 & 41 & 0.1225 & 1.1 & 3.40 & 2.7 & .2011 & 2.5 & .909 \\
\hline 3.1 & 0.23 & 508 & 295 & 0.60 & 83.9 & 1131 & \pm 24 & 2010 & \pm 22 & 44 & 0.1237 & 1.2 & 3.271 & 2.6 & 0.1918 & 2.3 & .882 \\
\hline 4.1 & 0.55 & 609 & 331 & 0.56 & 86.1 & 978 & \pm 21 & 1763 & \pm 26 & 45 & 0.1078 & 1.4 & 2.436 & 2.7 & 0.1638 & 2.3 & .848 \\
\hline 5.1 & 0.16 & 291 & 211 & 0.75 & 65.3 & 1496 & \pm 31 & 2126 & \pm 20 & 30 & 0.1321 & 1.1 & 4.76 & 2.6 & 0.2613 & 2.3 & .898 \\
\hline
\end{tabular}




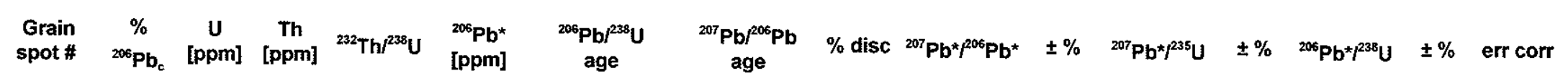

\begin{tabular}{|c|c|c|c|c|c|c|c|c|c|c|c|c|c|c|c|c|c|}
\hline \multicolumn{18}{|c|}{ São Rafael (SR) augen gneiss (cont.) } \\
\hline 6.1 & 0.03 & 360 & 259 & 0.74 & 69.9 & 1312 & \pm 27 & 2038 & \pm 18 & 36 & 0.1257 & 1.0 & 3.912 & 2.5 & 0.2258 & 2.3 & .912 \\
\hline 7.1 & 0.53 & 460 & 256 & 0.57 & 72.6 & 1082.2 & 25.2 & 1731 & \pm 22 & 37 & 0.1060 & 1.2 & 2.67 & 2.8 & .1828 & 2.5 & .903 \\
\hline 8.1 & 0.61 & 505 & 198 & 0.40 & 74.4 & 1015.1 & 23.7 & 1742 & \pm 21 & 42 & 0.1066 & 1.2 & 2.51 & 2.8 & .1705 & 2.5 & .908 \\
\hline 9.1 & 0.22 & 438 & 223 & 0.53 & 62.3 & 985.6 & 23.1 & 1657 & \pm 19 & 41 & 0.1018 & 1.0 & 2.32 & 2.7 & .1652 & 2.5 & .929 \\
\hline 10.1 & 0.48 & 391 & 297 & 0.78 & 66.2 & 1154.6 & 26.7 & 1797 & \pm 20 & 36 & 0.1098 & 1.1 & 2.97 & 2.8 & .1961 & 2.5 & .916 \\
\hline 11.1 & 0.21 & 339 & 228 & 0.70 & 72.9 & 1436.1 & 32.8 & 2022 & \pm 17 & 29 & 0.1245 & 1.0 & 4.28 & 2.7 & .2495 & 2.5 & .936 \\
\hline 12.1 & 0.84 & 442 & 359 & 0.84 & 48.6 & 769.4 & 18.5 & 1323 & \pm 53 & 42 & 0.0853 & 2.7 & 1.49 & 3.8 & .1268 & 2.6 & 681 \\
\hline 13.1 & 0.13 & 274 & 159 & 0.60 & 78.4 & 1853.8 & 42.0 & 2135 & \pm 19 & 13 & 0.1328 & 1.1 & 6.10 & 2.8 & .3332 & 2.6 & .927 \\
\hline \multicolumn{18}{|c|}{ São José do Seridó (SJS) augen gneiss } \\
\hline 1.1 & 0.05 & 267 & 105 & 0.41 & 91.1 & 2154 & \pm 42 & 2263 & \pm 14 & 5 & 0.1429 & 0.80 & 7.82 & 2.4 & 0.3967 & 2.3 & .944 \\
\hline 2.1 & 0.45 & 524 & 226 & 0.45 & 151 & 1855 & \pm 37 & 2234 & \pm 14 & 17 & 0.1406 & 0.82 & 6.46 & 2.4 & 0.3334 & 2.3 & .941 \\
\hline 3.1 & 0.00 & 154 & 77 & 0.52 & 51.2 & 2113 & \pm 42 & 2206 & \pm 20 & 4 & 0.1383 & 1.2 & 7.40 & 2.6 & 0.3879 & 2.4 & .896 \\
\hline 4.1 & 0.39 & 345 & 178 & 0.53 & 109 & 2003 & \pm 39 & 2447 & \pm 15 & 18 & 0.1592 & 0.92 & 8.00 & 2.5 & 0.3644 & 2.3 & .928 \\
\hline 5.1 & 0.00 & 385 & 141 & 0.38 & 118 & 1969 & \pm 39 & 2217 & \pm 12 & 11 & 0.13917 & 0.71 & 6.86 & 2.4 & 0.3573 & 2.3 & .954 \\
\hline 6.1 & 0.13 & 412 & 149 & 0.37 & 107 & 1699 & \pm 34 & 2228 & \pm 14 & 24 & 0.1400 & 0.82 & 5.82 & 2.4 & 0.3016 & 2.3 & .942 \\
\hline 6.2 & 0.04 & 387 & 139 & 0.37 & 101 & 1713 & \pm 34 & 2201 & \pm 14 & 22 & 0.1379 & 0.82 & 5.79 & 2.4 & 0.3044 & 2.3 & .942 \\
\hline 7.1 & 0.17 & 477 & 154 & 0.33 & 119 & 1643 & \pm 33 & 2249 & \pm 17 & 27 & 0.1418 & 0.97 & 5.67 & 2.5 & 0.2903 & 2.3 & .921 \\
\hline 8.1 & 0.15 & 733 & 226 & 0.32 & 193 & 1720 & \pm 34 & 2272 & \pm 11 & 24 & 0.14366 & 0.66 & 6.06 & 2.4 & 0.3059 & 2.3 & .960 \\
\hline 9.1 & 0.00 & 103 & 86 & 0.86 & 28.1 & 1770 & \pm 38 & 2300 & \pm 25 & 23 & 0.1460 & 1.5 & 6.36 & 2.8 & 0.3159 & 2.4 & .860 \\
\hline 10.1 & 0.06 & 2904 & 1709 & 0.61 & 369 & 888 & \pm 19 & 3428 & \pm 18 & 74 & 0.2920 & 1.2 & 5.95 & 2.5 & 0.1477 & 2.2 & .885 \\
\hline 11.1 & 0.02 & 420 & 265 & 0.65 & 123 & 1896 & \pm 38 & 2261 & \pm 13 & 16 & 0.1428 & 0.75 & 6.73 & 2.4 & 0.3420 & 2.3 & .951 \\
\hline 12.1 & 0.02 & 348 & 166 & 0.49 & 99.3 & 1847 & \pm 39 & 2376 & \pm 14 & 22 & 0.1527 & 0.79 & 6.98 & 2.6 & 0.3317 & 2.5 & .951 \\
\hline 13.1 & 0.00 & 484 & 120 & 0.26 & 132 & 1775 & \pm 36 & 2196 & \pm 12 & 19 & 0.13749 & 0.70 & 6.01 & 2.4 & 0.3170 & 2.3 & .957 \\
\hline 14.1 & 0.73 & 807 & 425 & 0.54 & 74.4 & 652 & \pm 14 & 1238 & \pm 43 & 47 & 0.0817 & 2.2 & 1.199 & 3.2 & 0.1065 & 2.3 & .725 \\
\hline 15.1 & 0.20 & 428 & 258 & 0.62 & 74.1 & 1181 & \pm 26 & 1993 & \pm 20 & 41 & 0.1225 & 1.1 & 3.395 & 2.7 & 0.2010 & 2.5 & .909 \\
\hline \multicolumn{18}{|c|}{ Santana do Matos (SM-3) augen gneiss } \\
\hline 1.1 & 0.01 & 448 & 247 & 0.57 & 145 & 2064 & \pm 25 & 2211 & \pm 11 & 7 & 0.13866 & 0.65 & 7.22 & 1.5 & 0.3774 & 1.4 & .906 \\
\hline 2.1 & 0.01 & 406 & 241 & 0.61 & 136 & 2123 & \pm 25 & 2201 & \pm 12 & 4 & 0.13792 & 0.67 & 7.42 & 1.6 & 0.3900 & 1.4 & .902 \\
\hline 3.1 & 0.00 & 391 & 333 & 0.88 & 127 & 2072 & \pm 25 & 2208 & \pm 12 & 6 & 0.13848 & 0.70 & 7.24 & 1.6 & 0.3790 & 1.4 & .897 \\
\hline 4.1 & 0.02 & 316 & 241 & 0.79 & 105 & 2104 & \pm 26 & 2231 & \pm 13 & 6 & 0.1403 & 0.78 & 7.47 & 1.6 & 0.3860 & 1.5 & .882 \\
\hline 5.1 & 0.25 & 910 & 187 & 0.21 & 178 & 1317 & \pm 16 & 1940 & \pm 14 & 32 & 0.11892 & 0.79 & 3.718 & 1.6 & 0.2267 & 1.3 & .863 \\
\hline $5.2[r]$ & 0.00 & 455 & 330 & 0.75 & 152 & 2115 & \pm 26 & 2212 & \pm 11 & 4 & 0.13881 & 0.64 & 7.43 & 1.6 & 0.3884 & 1.4 & .913 \\
\hline 6.1 & 0.06 & 128 & 102 & 0.82 & 45.3 & 2225 & \pm 32 & 2184 & \pm 21 & -2 & 0.1366 & 1.2 & 7.76 & 2.0 & 0.4122 & 1.7 & .818 \\
\hline 7.1 & 0.01 & 646 & 230 & 0.37 & 194 & 1937 & \pm 23 & 2186 & \pm 10 & 11 & 0.13668 & 0.56 & 6.606 & 1.5 & 0.3505 & 1.4 & .924 \\
\hline 8.1 & 0.00 & 581 & 327 & 0.58 & 183 & 2016 & \pm 24 & 2202 & \pm 11 & 8 & 0.13797 & 0.64 & 6.98 & 1.5 & 0.3671 & 1.4 & .904 \\
\hline 9.1 & 0.06 & 237 & 241 & 1.05 & 79.3 & 2118 & \pm 27 & 2165 & \pm 15 & 2 & 0.1351 & 0.88 & 7.24 & 1.7 & 0.3891 & 1.5 & .861 \\
\hline 10.1 & 0.05 & 435 & 448 & 1.07 & 150 & 2174 & \pm 26 & 2206 & \pm 11 & 1 & 0.13828 & 0.64 & 7.65 & 1.5 & 0.4010 & 1.4 & .909 \\
\hline
\end{tabular}




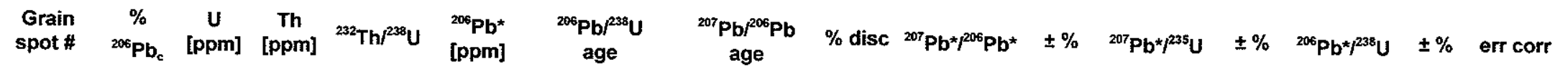

\begin{tabular}{|c|c|c|c|c|c|c|c|c|c|c|c|c|c|c|c|c|c|}
\hline \multicolumn{18}{|c|}{ Santana do Matos (SM-4) leucogneiss } \\
\hline 1.1 & 0.05 & 478 & 332 & 0.72 & 158 & 2095 & \pm 25 & 2239 & \pm 11 & 6 & 0.14094 & 0.62 & 7.46 & 1.5 & 0.3840 & 1.4 & .914 \\
\hline 2.1[ex] & 0.78 & 437 & 192 & 0.45 & 128 & 1877 & \pm 23 & 2225 & \pm 26 & 16 & 0.1399 & 1.5 & 6.52 & 2.1 & 0.3380 & 1.4 & .686 \\
\hline $2.2[\mathrm{in}]$ & 0.43 & 666 & 350 & 0.54 & 205 & 1965 & \pm 23 & 2231 & \pm 12 & 12 & 0.14032 & 0.71 & 6.89 & 1.5 & 0.3563 & 1.4 & .888 \\
\hline $2.3[\mathrm{c}]$ & 0.38 & 2449 & 1324 & 0.56 & 405 & 1131 & \pm 14 & 2234 & \pm 9.6 & 49 & 0.14059 & 0.55 & 3.718 & 1.4 & 0.1918 & 1.3 & .920 \\
\hline 3.1 & 0.05 & 579 & 611 & 1.09 & 177 & 1964 & \pm 24 & 2191 & \pm 12 & 10 & 0.13708 & 0.70 & 6.73 & 1.6 & 0.3562 & 1.4 & .896 \\
\hline 7.1 & 0.00 & 279 & 179 & 0.66 & 95.7 & 2167 & \pm 27 & 2234 & \pm 24 & 3 & 0.1405 & 1.4 & 7.74 & 2.0 & 0.3995 & 1.5 & .726 \\
\hline 10.1[ex] & 0.24 & 309 & 232 & 0.77 & 102 & 2090 & \pm 26 & 2226 & \pm 16 & 6 & 0.1399 & 0.90 & 7.39 & 1.7 & 0.3829 & 1.5 & .850 \\
\hline 10.2[in] & 1.46 & 1174 & 337 & 0.30 & 136 & 803 & \pm 11 & 2168 & \pm 22 & 63 & 0.1353 & 1.2 & 2.474 & 2.0 & 0.1326 & 1.5 & .770 \\
\hline 11.1 & 0.12 & 1095 & 384 & 0.36 & 345 & 2009 & \pm 23 & 2218 & \pm 7.8 & 9 & 0.13925 & 0.45 & 7.023 & 1.4 & 0.3658 & 1.3 & .945 \\
\hline \multicolumn{18}{|c|}{ Antonio Martins (AM) augen gneiss } \\
\hline 1.1 & 0.82 & 66 & 48 & 0.76 & 22.7 & 2152.8 & \pm 52 & 2112 & \pm 37 & -2 & 0.1310 & 2.1 & 7.16 & 3.5 & .3965 & 2.8 & .806 \\
\hline 2.1 & 0.53 & 87 & 71 & 0.84 & 28.7 & 2077.4 & \pm 49 & 2186 & \pm 37 & 5 & 0.1367 & 2.1 & 7.17 & 3.5 & .3802 & 2.8 & .797 \\
\hline 3.1 & 0.88 & 77 & 48 & 0.65 & 27.8 & 2233.4 & \pm 53 & 2192 & \pm 42 & -2 & 0.1372 & 2.4 & 7.83 & 3.7 & .4141 & 2.8 & .756 \\
\hline 4.1 & 0.93 & 75 & 44 & 0.60 & 25.4 & 2127.7 & \pm 51 & 2193 & \pm 33 & 3 & 0.1373 & 1.9 & 7.40 & 3.4 & .3910 & 2.8 & .832 \\
\hline 5.1 & 0.22 & 123 & 56 & 0.48 & 42.4 & 2173.8 & \pm 52 & 2135 & \pm 25 & -2 & 0.1327 & 1.4 & 7.34 & 3.2 & .4010 & 2.8 & .891 \\
\hline 6.1 & 0.64 & 116 & 61 & 0.54 & 28.8 & 1624.3 & \pm 39 & 2067 & \pm 37 & 21 & 0.1277 & 2.1 & 5.05 & 3.4 & .2866 & 2.7 & .792 \\
\hline 7.1 & 0.54 & 129 & 89 & 0.71 & 43.0 & 2100.5 & \pm 56 & 2144 & \pm 32 & 2 & 0.1334 & 1.8 & 7.09 & 3.6 & .3852 & 3.1 & .862 \\
\hline 8.1 & 0.45 & 88 & 72 & 0.85 & 29.1 & 2095.6 & \pm 75 & 2202 & \pm 30 & 5 & 0.1380 & 1.8 & 7.31 & 4.5 & .3841 & 4.2 & .923 \\
\hline 9.1 & 0.28 & 163 & 95 & 0.60 & 53.3 & 2074.5 & \pm 48 & 2165 & \pm 20 & 4 & 0.1351 & 1.1 & 7.07 & 3.0 & .3796 & 2.7 & .923 \\
\hline 10.1 & 0.62 & 103 & 94 & 0.94 & 34.6 & 2115.3 & \pm 50 & 2169 & \pm 30 & 2 & 0.1354 & 1.7 & 7.25 & 3.3 & .3884 & 2.8 & .850 \\
\hline 11.1 & 0.24 & 146 & 71 & 0.51 & 43.7 & 1927.3 & \pm 45 & 2145 & \pm 23 & 10 & 0.1335 & 1.3 & 6.42 & 3.0 & .3485 & 2.7 & .900 \\
\hline $12.1[r]$ & 0.44 & 154 & 85 & 0.57 & 45.1 & 1883.9 & \pm 44 & 2156 & \pm 24 & 13 & 0.1344 & 1.4 & 6.29 & 3.0 & .3394 & 2.7 & .895 \\
\hline 12.2 & 0.66 & 126 & 88 & 0.72 & 38.0 & 1922.9 & \pm 46 & 2134 & \pm 29 & 10 & 0.1327 & 1.7 & 6.36 & 3.2 & .3475 & 2.8 & .857 \\
\hline \multicolumn{18}{|c|}{ Serra Negra (SN) augen gneiss } \\
\hline 1.1 & 0.13 & 116 & 91 & 0.81 & 30.2 & 1709 & \pm 24 & 1741 & \pm 20 & 2 & 0.1066 & 1.1 & 4.460 & 2.0 & 0.3036 & 1.6 & .826 \\
\hline $2.1[r]$ & 0.02 & 301 & 27 & 0.09 & 27.5 & 639 & \pm 24 & 630 & \pm 32 & -1 & 0.06074 & 1.5 & 0.873 & 4.0 & 0.1042 & 3.8 & .930 \\
\hline 2.2 & 0.02 & 305 & 158 & 0.54 & 78.5 & 1686 & \pm 20 & 1732 & \pm 12 & 3 & 0.10604 & 0.65 & 4.372 & 1.5 & 0.2990 & 1.4 & .900 \\
\hline 3.1 & 0.08 & 118 & 75 & 0.66 & 31.5 & 1744 & \pm 23 & 1714 & \pm 23 & -2 & 0.1050 & 1.3 & 4.499 & 2.0 & 0.3107 & 1.5 & .768 \\
\hline 4.1 & 0.16 & 249 & 145 & 0.60 & 63.9 & 1685 & \pm 20 & 1737 & \pm 12 & 3 & 0.10629 & 0.67 & 4.378 & 1.5 & 0.2988 & 1.4 & .899 \\
\hline 5.1 & 0.09 & 93 & 57 & 0.63 & 24.1 & 1696 & \pm 24 & 1773 & \pm 24 & 4 & 0.1084 & 1.3 & 4.500 & 2.1 & 0.3010 & 1.6 & .775 \\
\hline $5.2[r]$ & 0.74 & 289 & 15 & 0.05 & 37.5 & 901 & \pm 13 & 926 & \pm 55 & 3 & 0.0699 & 2.7 & 1.445 & 3.1 & 0.1499 & 1.6 & .499 \\
\hline 6.1 & 0.33 & 678 & 237 & 0.36 & 152 & 1491 & \pm 21 & 1738 & \pm 14 & 14 & 0.10635 & 0.74 & 3.817 & 1.7 & 0.2603 & 1.5 & .902 \\
\hline $6.2[r]$ & 0.22 & 360 & 41 & 0.12 & 73.7 & 1375 & \pm 14 & 1640 & \pm 14 & 16 & 0.10085 & 0.78 & 3.306 & 1.4 & 0.2377 & 1.1 & .853 \\
\hline 7.1 & 0.07 & 325 & 176 & 0.56 & 84.1 & 1697 & \pm 45 & 1739 & \pm 14 & 2 & 0.1064 & 0.74 & 4.420 & 3.1 & 0.3011 & 3.0 & .971 \\
\hline $9.1 \mathrm{c}$ & 0.32 & 399 & 188 & 0.49 & 138 & 2180 & \pm 26 & 2196 & \pm 21 & 1 & 0.1375 & 1.2 & 7.630 & 1.8 & 0.4023 & 1.4 & .756 \\
\hline
\end{tabular}




\begin{tabular}{|c|c|c|c|c|c|c|c|c|c|c|c|c|c|c|c|c|c|}
\hline \multirow{2}{*}{$\begin{array}{c}\begin{array}{c}\text { Grain } \\
\text { spot \# }\end{array} \\
\text { Serra Neg }\end{array}$} & \multirow{2}{*}{$\begin{array}{c}\% \\
{ }^{206} \mathrm{~Pb}_{\mathrm{c}} \\
(\mathrm{SN}) \mathrm{au}\end{array}$} & \multirow{2}{*}{$\begin{array}{c}\begin{array}{c}\text { U } \\
\text { [ppm] }\end{array} \\
\text { gengne }\end{array}$} & \multirow{2}{*}{$\begin{array}{c}\begin{array}{c}\text { Th } \\
\text { [ppm] }\end{array} \\
\text { iss (con }\end{array}$} & \multirow{2}{*}{${ }^{{ }^{232} \mathrm{Th} /{ }^{238} \mathrm{U}}$} & \multirow[t]{2}{*}{$\begin{array}{l}{ }^{206} \mathrm{~Pb}^{*} \\
{[\mathrm{ppm}]}\end{array}$} & \multicolumn{2}{|c|}{$\begin{array}{c}{ }^{206} \mathrm{~Pb} /{ }^{238} \mathrm{U} \\
\text { age }\end{array}$} & \multicolumn{2}{|c|}{$\begin{array}{c}{ }^{207} \mathrm{~Pb} /{ }^{206} \mathrm{~Pb} \\
\text { age }\end{array}$} & \multirow[t]{2}{*}{$\%$ disc } & \multirow[t]{2}{*}{${ }^{207} \mathrm{~Pb}^{\star} P^{206} \mathrm{~Pb}^{\star}$} & \multirow[t]{2}{*}{ $\pm \%$} & \multirow[t]{2}{*}{${ }^{207} \mathrm{~Pb}^{\star}{ }^{235} \mathrm{U}$} & \multirow[t]{2}{*}{ $\pm \%$} & \multirow[t]{2}{*}{${ }^{206} \mathrm{~Pb}^{\star} /{ }^{238} \mathrm{U}$} & \multirow[t]{2}{*}{ $\pm \%$} & \multirow[t]{2}{*}{ err corr } \\
\hline & & & & & & & & & & & & & & & & & \\
\hline $12.2[r]$ & 0.22 & 157 & 12 & 0.08 & 14.9 & 672 & \pm 8.4 & 814 & \pm 43 & 17 & 0.0662 & 2.1 & 1.003 & 2.5 & 0.1099 & 1.3 & .538 \\
\hline 13.1 & 0.10 & 500 & 189 & 0.39 & 140 & 1817 & \pm 18 & 1743 & \pm 8.9 & -4 & 0.10663 & 0.48 & 4.786 & 1.2 & 0.3256 & 1.1 & .917 \\
\hline 13.2 & 0.07 & 62 & 35 & 0.59 & 17.1 & 1779 & \pm 25 & 1765 & \pm 26 & -1 & 0.1080 & 1.4 & 4.730 & 2.1 & 0.3178 & 1.6 & .747 \\
\hline 14.1 & 0.00 & 69 & 43 & 0.65 & 18.6 & 1754 & \pm 22 & 1745 & \pm 20 & 0 & 0.1068 & 1.1 & 4.602 & 1.8 & 0.3126 & 1.4 & .791 \\
\hline
\end{tabular}

Errors for isotopic ratios are quoted at $1 \mathrm{~s}$ level; $\mathrm{Pbc}$ and $\mathrm{Pb^{ \star }}$ indicate common and radiogenic portions, respectively.

Error in standard calibration was $0.62 \%$ for BGSL and RF, $0.55 \%$ for SJS and SR, $0.32 \%$ for SM-3 and SM-4, 0.42\% for AM, and $0.49 \%$ for SN (not included in above errors but required when comparing data from different mounts).

For all analyses common $\mathrm{Pb}$ was corrected using measured $204 \mathrm{~Pb}$, except analysis \#2.1 ( $\mathrm{SN}$ sample) for which correction was made by assuming ${ }^{206} \mathrm{~Pb} \mathrm{f}^{\mathrm{p} 3} \mathrm{U}^{208} \mathrm{~Pb} \mathrm{P}^{32} \mathrm{Th}$ ageconcordance.

Spots are on: $[r]=U$-rich overgrowth; $[\mathrm{ex}]=$ extemal igneous sector in the grain; $[\mathrm{in}]=$ intemal ogneous sector in the grain; $[\mathrm{c}]=(\mathrm{supposed})$ core. 
Table 2. ID-TIMS Nd isotopic data and related parameters for augen gneisses and metaleucogabbro from the northeastern Borborema Province.

\begin{tabular}{lccccccccc}
\hline Sample & $\begin{array}{c}S \mathrm{Sm} \\
{[\mathrm{ppm}]}\end{array}$ & $\begin{array}{c}\mathrm{Nd} \\
{[\mathrm{ppm}]}\end{array}$ & ${ }^{147} \mathrm{Sm} /{ }^{144} \mathrm{Nd}$ & $\begin{array}{c}\mathrm{err} \\
{[1 \sigma]}\end{array}$ & ${ }^{143} \mathrm{Nd} /^{144} \mathrm{Nd}$ & $\begin{array}{c}\mathrm{err} \\
{[2 \sigma]}\end{array}$ & $\begin{array}{c}\varepsilon_{\mathrm{Nd}} \\
{[t=0]}\end{array}$ & $\begin{array}{c}\varepsilon_{\mathrm{Nd}} \\
{[t=\mathrm{see}} \\
\text { U/Pb ages }]\end{array}$ & $t_{\mathrm{DM}}$ \\
\hline$S L$ & 13.469 & 106.56 & 0.0764 & 0.0005 & 0.510715 & 0.000012 & -37.51 & -0.39 & 2.60 \\
$R F$ & 0.230 & 1.043 & 0.1336 & 0.0008 & 0.511390 & 0.000014 & -24.34 & -7.03 & 3.20 \\
$S R$ & 7.733 & 46.96 & 0.0996 & 0.0003 & 0.511025 & 0.000009 & -31.46 & -3.91 & 2.72 \\
$S J S$ & 7.691 & 41.95 & 0.1109 & 0.0004 & 0.511167 & 0.000009 & -28.69 & -3.91 & 2.81 \\
$S M-3$ & 2.613 & 10.24 & 0.1543 & 0.0009 & 0.511183 & 0.000013 & -28.38 & -16.43 & 5.18 \\
$S M-4$ & 5.125 & 30.87 & 0.1004 & 0.0006 & 0.511141 & 0.000012 & -29.20 & -1.86 & 2.57 \\
AM & 13.013 & 86.89 & 0.0906 & 0.0005 & 0.511023 & 0.000012 & -31.50 & -1.93 & 2.51 \\
$S N$ & 11.926 & 79.02 & 0.0913 & 0.0005 & 0.511081 & 0.000013 & -30.37 & -6.87 & 2.45 \\
$J P$ & 6.102 & 38.25 & 0.0965 & 0.0006 & 0.511078 & 0.000009 & -30.43 & -2.77 & 2.57 \\
$S P I$ & 5.198 & 31.83 & 0.0988 & 0.0006 & 0.511036 & 0.000014 & -31.25 & -3.59 & 2.68 \\
\hline
\end{tabular}

$\mathrm{Nd}$ isotopic ratios were determined as $\mathrm{Nd}^{+}$; correction for mass-dependent fractionation was made by normalization to ${ }^{146} \mathrm{Nd}{ }^{144} \mathrm{Nd}=0.7219$ (De Paolo, 1981). ${ }^{147} \mathrm{Sm}$ decay constant is $6,54 \times 10^{-12} a^{-1}$ (Lugmair and Marti, 1978). eNd parameters were calculated relative to CHUR with ${ }^{143} \mathrm{Nd} /{ }^{144} \mathrm{Nd}=0.512638$ and ${ }^{147} \mathrm{Sm} /{ }^{144} \mathrm{Nd}=0.1967$ (Hamilton et al., 1983). Initial eNd values were calculated from the U-Pb SHRIMP zircon ages quoted in the present study. Depleted mantle model age $\left(t_{D M}\right)$ were calculated following the model of De Paolo et al. (1991). Analyses of JNdi-1 standard (Geological Survey of Japan) yielded ${ }^{143} \mathrm{Nd} /{ }^{144} \mathrm{Nd}=0.512115 \pm 0.000013$. Analytical blanks during procedures were $10-15 \mathrm{pg} / \mathrm{g}$ for $\mathrm{Sm}$ and $50-55 \mathrm{pg} / \mathrm{g}$ for $\mathrm{Nd}$. See text for details on abbreviation of the studied samples. 


\section{CAPÍTULO 3}

Artigo Timing of the HT/LP transpression in the Seridó Belt (Borborema Province, Brazil): constraints from U-Pb (SHRIMP) geochronology and implications for the connections between NE Brazil and West Africa, aceito no periódico Gondwana Research em abril 2012. 
Timing of the HT/LP transpression in the Neoproterozoic Seridó Belt

(Borborema Province, Brazil): constraints from U-Pb (SHRIMP) geochronology and implications for the connections between NE Brazil and West Africa

Carlos J. Archanjo ${ }^{1 *}$, Luiz G. F. Viegas ${ }^{1}$, Maria Helena B.M. Hollanda ${ }^{1}$, Laecio C. Souza ${ }^{2}$, Dunyi Liu ${ }^{3}$

1. Instituto de Geociências, Universidade de São Paulo, Rua do Lago 562, 05508-080, São Paulo, Brazil.

2. Departamento de Geologia, CCET/Universidade Federal do Rio Grande do Norte, 59000-000, Natal, Brazil.

3. Beijing SHRIMP Center, Chinese Academy of Geological Sciences, Beijing 10037, China.

\begin{abstract}
The Seridó schist belt is a classical domain of the Borborema Province (NE Brazil) recording crustal melting at HT/LP conditions in a tectonic setting dominated by dextral transpressive deformation. A comparable tectonometamorphic setting has been described in the Pan-African Igarra and llesha schist belts of south Nigeria (Africa). The HT transpression of the Seridó has previously been imprecisely dated by using a range of isotopic methods on a suite of syntectonic granites. We provide new U-Pb zircon ages of the Acari granite and Santa Luzia migmatite that constrain the HT/LP metamorphism of the Serido at c. $575 \mathrm{Ma}$. Anisotropy of magnetic susceptibility of the Santa Luzia migmatite shows that the magnetic fabric records the NE-trending dextral kinematics similar to those previously described in the Acari pluton. On the other hand, the U-Pb ages of the Totoro pluton provide evidence for an older, mostly mafic to intermediate magmatism intruding the pelitic schist that precedes the HT/LP metamorphism by approximately 15 m.y. In contrast with the Acari pluton and Santa Luzia migmatite, the magnetic fabrics of Totoró show a concentric steep-dipping structure apparently related to magma ascent. Thermobarometric studies in the Seridó, Igarra and llesha schist belts indicate that a large domain in the northern Borborema and south of the Nigeria shields was deformed at a high temperature and at relatively shallow depths. Although the tectonic setting for such a postcollision HT event remains an open issue, it allows us nevertheless to refine the across-Atlantic geological correlation between the continents.
\end{abstract}

\title{
Keywords
}

U-Pb (SHRIMP) geochronology, granite, AMS, Seridó belt, Neoproterozoic, NE Brazil 


\section{INTRODUCTION}

The break-up of West Gondwana in the Mesozoic led to the rupture of the BrasilianoPan African belts between the South American and African continents to form the Atlantic Ocean. To reassemble West Gondwana in order to define the key geodynamics elements of these continents requires, therefore, a fine adjustment between the rock records on both margins across Atlantic. However, despite a good fit between the platforms of the central and southern Atlantic, the precise correlation between the Neoproterozoic belts is still unresolved. Part of the problem is the perception that during their break-up and drift, the major continents have not always responded as single rigid blocks, leading to the distortion of the plates. To overcome this problem De Wit et al. (2008) proposed detailing the geology of ten piercing points to improve the correlations across the central and south Atlantic. Four of these piercing points are situated in the Borborema (NE Brazil) and Nigeria shields, and one of them corresponds to the vertical shear zones that deform the dominantly pelitic Neoproterozoic deposits (schist belts) of the Seridó-Jaguaribe and Igarra-Ifewara-llesha domains (Fig. 1; Caby et al. 2001; Arthaud et al., 2008).

A critical issue related to the Borborema and Nigeria shields is the age of the magmatism, metamorphism and associated structures. A suture zone that closed the Pharusian Ocean at c. $600 \mathrm{Ma}$ has been identified along the east margin of the West African craton through gravity anomalies and rock assemblages comprising mafic complex and high-pressure metamorphism (Attoh and Nude, 2008; Caby et al., 2008). Until now, no equivalent rock assemblages have been described on the Brazilian side. Thus, such a suture should be covered by Paleozoic sediments of the Parnaíba Basin. Some transcontinental shear zones that match across the Atlantic, such as the Transbrasiliano/Kandi and Senador Pompeu/lfewara (Fig. 1) resulted from collision processes and late accommodation structures due to the continued convergence of the cratons. In Seridó-Jaguaribe and Igarra-Ifewara domains, the shear zones coeval with the granitic magmatism are associated with a high temperature/lowpressure metamorphism (HT/LP; Lima, 1987; Zhe and Holness, 2003). However, there is growing evidence that some shear zones and associated plutons, dyke swarms and pegmatites (re)activate as late as in the Cambrian (Baumgartner et al., 2006; Archanjo et al., 2009; Hollanda et al., 2010). This implies that an accurate fit requires matching not only the vertical fault structures across the Atlantic, but also the timing in that tectono-magmatic events affected the rock record.

This study provides new U-Pb (SHRIMP) data for granites and migmatites formed during the HT/LP transpression that deformed the Seridó schist belt (Fig. 1 and 2). It combines zircon geochronology with the study of magmatic fabric using the anisotropy of magnetic susceptibility (AMS). In a pre-drift reconstruction the Seridó matches with the schist belts of the East Nigeria 
shield (Dada, 2008), particularly with the Igarra sequence (Omitogun et al., 1991). The Seridó is bounded to the south by the Patos shear zone that, in Nigeria, probably connects with the tectonic line that separates the East from the West Nigeria basement (Van Schmus et al., 2008). The Seridó is a classical domain of the Borborema Province that has been extensively studied due to its important mineral deposits ( $\mathrm{Au}$ in quartz-veins, $\mathrm{W}$ in skarns and $\mathrm{Ta}-\mathrm{Nb}$ in pegmatites and semi-precious stones). Although the structure and geochemistry of magmatic rocks have been studied in some detail (Leterrier et al., 1994; Araújo et al., 2001; Hollanda et al., 2003; Archanjo et al., 2002), an accurate chronology of the igneous pulses and the relationship with deformation remains an open issue. We provide reliable crystallisation ages for zircons of syntectonic plutons as well as for overgrowths of inherited zircons that survived the migmatisation of the basement, that allow us to constrain the timing of the HT/LP events. In addition, magnetic fabric data in migmatites indicate that the melting of the basement rocks was coeval with the emplacement of granitic plutons and transpressive deformation recorded along the Seridó-Patos shear system.

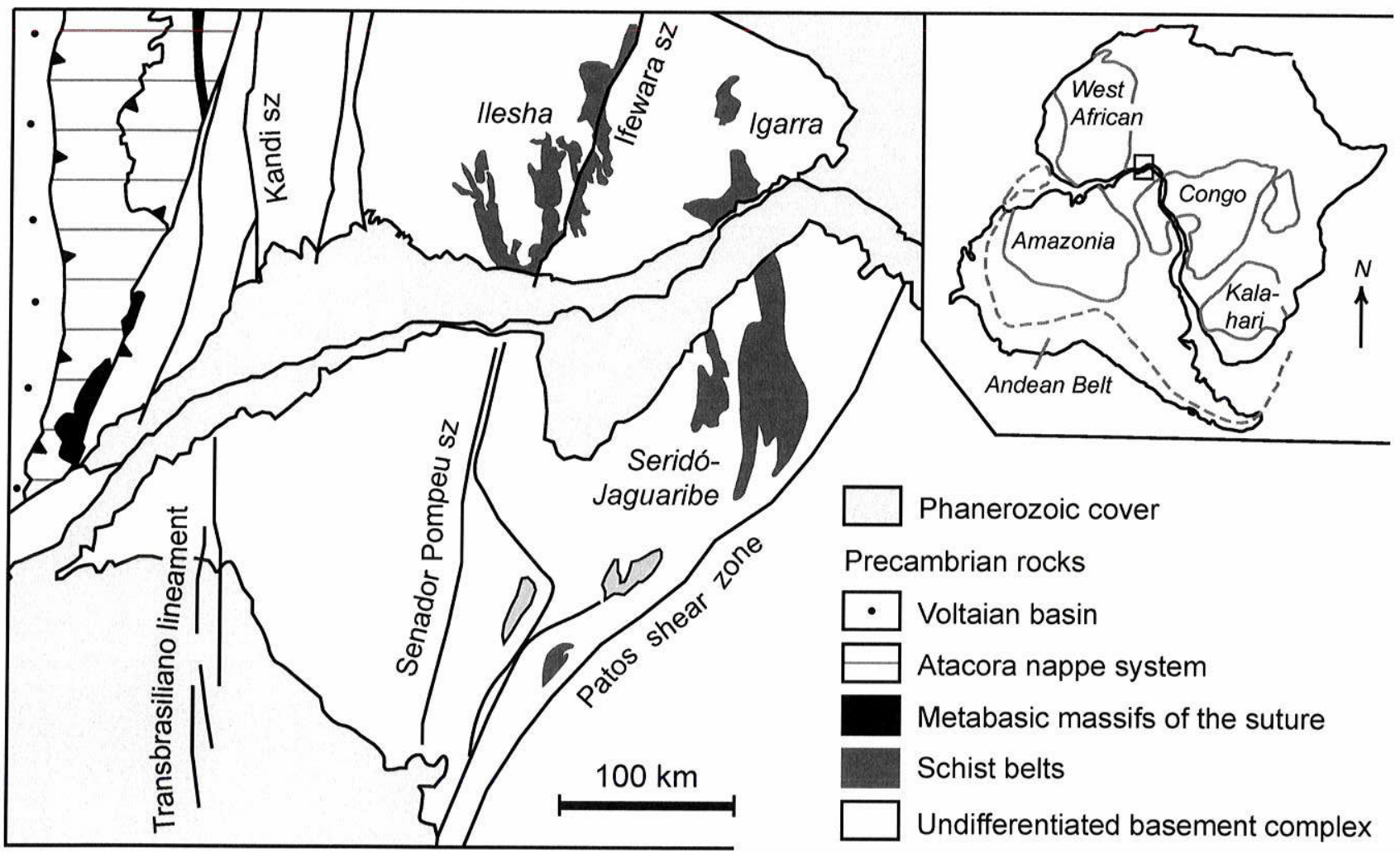

Figure 1. Pre-Mesozoic fit between the northern Borborema Province (NE Brazil) and southern Nigerian shield (Africa) highlighting the schist belts and main vertical shear zones (sz). Inset: Sketch map of the West Gondwana and the study area between the Congo and West African cratons. The geology of south Nigeria after Caby and Boessé (2001). 


\section{GEOLOGICAL SETTING}

\subsection{The Seridó belt}

The Serido defines the NE trending schist belt covered to the north by the sediments of the Mesozoic Potiguar basin and bordered to the south by the E-trending Patos shear zone (Fig. 2). The belt is flanked by an older Paleoproterozoic basement of 2.1 to $2.4 \mathrm{Ga}$ in age, named the Caicó Complex, which includes local Archean rocks (Dantas et al., 2004; Souza et al., 2008; Hollanda et al., 2011). An unconformity separates the basement from the succession of mainly clastic Neoproterozoic sedimentary rocks that is known as the Seridó Group. The group comprises a thick metaturbidite deposit above a clastic sequence of quartzite and metaconglomerate. Marble and paragneiss associated with calc-silicate rocks may be found locally below the psamo-pelitic sequence or near the base of the Seridó schist.

The deformation in the Seridó Group is characterised by a main phase that formed upright to inclined, open-to-tight NE trending folds, associated with a variably dipping schistosity with a common fan-like appearance (Archanjo and Bouchez, 1991; Araújo et al., 2005). This event overprints a gentle-dipping foliation and recumbent folds attributed to a former thrust tectonics. In the core of large synclinorial structures, such as around the Cruzeta dam (Fig. 3), greenschist facies conditions are preserved. Towards the central domain of the belt, the temperature increases to form andalusite, cordierite and sillimanite in aluminous schists accompanied by abundant quartz-feldspathic veins, aplitic dykes and granite intrusions. Exposures of the contact between the gneissic basement and cover rocks, such as those to the southwest around Santa Luzia, are deeply migmatised. Thermobarometric data using garnetbiotite and plagioclase-garnet exchange reactions along E-W traverses crossing FlorâniaCurrais Novos, Cruzeta-Acari and Jardim do Seridó-Carnaúba dos Dantas (Fig. 3) allowed Lima (1987) to estimate a thermal gradient of $30-40{ }^{\circ} \mathrm{C} / \mathrm{km}$. Temperatures below $500{ }^{\circ} \mathrm{C}$ and pressures of about $3 \mathrm{kbar}$ are recorded to the west approaching the core of the Cruzeta synform. Flanking the Acari pluton the temperatures increase up to $620^{\circ} \mathrm{C}$ at pressures of 4 kbar. Stretched conglomerate clasts and elongated porphyroblasts of cordierite and andalusite are subhorizontal and parallel to oblique relative to main elongation of the belt. Kinematic criteria using C-C'-S planes and asymmetrical porphyroclasts are systematically dextral and include a component of flattening normal to the regional NE-trending foliation (Archanjo and Bouchez, 1991). 


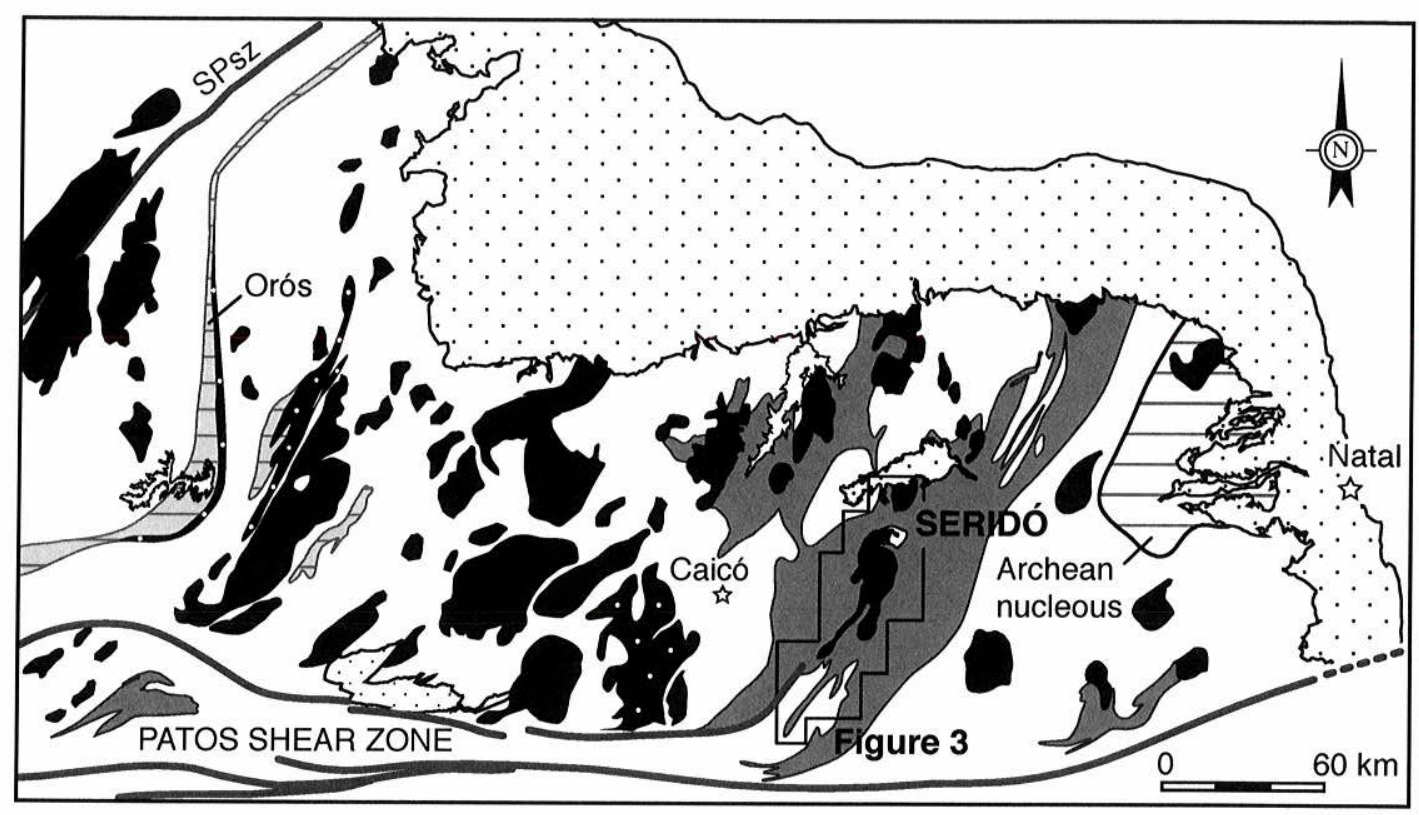

Paleoproterozoic

Neoproterozoic

$\Xi$ (meta)volcano-sedimentary rocks

granite

- orthogneiss

$\square$ gneiss and migmatite

metapelite, quartzite, marble (Seridó Group)

Figure 2. Simplified geological map of the Seridó-Jaguaribe domain. SPSZ, Senador Pompeu shear zone.

The Acari pluton consists of a porphyritic syeno- to monzogranite with biotite and hastingsitic to Fe-edenite hornblende. Lenses of biotite diorite, which sometimes occur as large angular enclaves, usually display features of mixing and mingling with granites. Sheet-like equigranular leucogranite often occupies the periphery of the batholith. The Totoro pluton consist of a monzodiorite to porphyritic quartz monzonite, including small stocks of diorite and gabbronorite. Mixing and mingling features between mafic and felsic magmas are common. Geochemical Harker's diagrams show lower $\mathrm{SiO}_{2}$ and higher $\mathrm{FeO}$ and $\mathrm{MgO}$ contents in Totoró compared to Acari, which essentially indicate the more mafic composition of the former (Nascimento et al., 2000).

Field structures and AMS studies show that the Acari pluton is syntectonic due to the high temperature dextral transpressive deformation of the metapelites (Jardim de Sá et al., 1986; Archanjo et al., 2002). The feldspar megacrystals of the Acari display a well-defined shape fabric parallel to the pluton elongation; however, this locally bends to outline a plutonscale dextral magmatic shear zone (Fig. 3). The magnetic fabric is well-organised throughout with steep foliations mimetising the C-S surfaces of the shear zone at the centre of the intrusion, while lineations plunge to the SW. In contrast, magnetic foliation in the Totoro shows a concentric pattern with inward down to dip lineations. The contrasting internal structures of the Acari and Totoró lead Archanjo et al. (2002) to suggest that these plutons have different 
emplacement histories such that the fabric of Totoró traces the magma ascent. Available geochronological data (U/Pb TIMs, $\mathrm{Rb} / \mathrm{Sr}$ ) are restricted to the Acari granite. A single zircon fraction of a diorite provided a U/Pb age of $579 \pm 7 \mathrm{Ma}$ (Leterrier et al., 1994) while zircons from the porphyritic granite facies yielded a discordant age of $555 \pm 5 \mathrm{Ma}$ (Legrand et al., 1991). Furthermore, monazite from a leucogranite yielded an age of $528 \pm 12 \mathrm{Ma}$ (Baumgartner et al., 2006). These results indicate that the diorites are older than the granites but they conflict with field evidences suggesting that the diorites and porphyritic granites coexisted at the magmatic stage. Part of the difficulty in dating the Acari granite by isotope dilution on zircon may be related to the strong isotopic inheritance recorded in the Seridó granites (Van Schmus et al., 2008). Accordingly, we opted to study the Totoró and Acari plutons by using punctual (SHRIMP) analysis where primary igneous zoning of zircons was previously detected by cathodoluminescence images.

\subsection{Geochronology of the Totoró and Acari plutons}

\subsubsection{Sampling and analytical methods}

We collected three samples from the Totoró (a gabbro, a diorite and a porphyritic granite) and two samples from the Acari (a coarse porphyritic granite and an equigranular leucogranite; see locations in Fig. 3). All samples were prepared using standard crushing and separating procedures. Zircon grains were hand-picked from the mineral separates mounted in epoxy together with chips of TEMORA 1 reference zircon $\left({ }^{206} \mathrm{~Pb} /{ }^{238} \mathrm{U}=416.75 \pm 0.24 \mathrm{Ma}\right.$; Black et al., 2003), sectioned approximately in half and polished. Reflected and transmitted light photomicrographs and cathodoluminescence $(C L)$ SEM images were prepared for all grains. The spot areas (about 20-30 $\mu \mathrm{m}$ in diameter) for isotopic analysis were chosen in igneous growth sectors to obtain the zircon crystallisation ages. The analyses of U-Th- $\mathrm{Pb}$ were conducted using the SHRIMP II at the Beijing SHRIMP Centre (China), and a summary of the isotopic results is listed in Table 1. The isotopic data were collected in sets of five scans throughout the masses, and the TEMORA standard was measured every third unknown analysis. The abundances of $\mathrm{U}, \mathrm{Th}$ and $\mathrm{Pb}$, as well as the $\mathrm{Pb}$ isotope ratios, were normalised using the $\mathrm{SL} 13$ zircon standard $(\mathrm{U}=238 \mathrm{ppm})$. Common $\mathrm{Pb}$ was corrected using the measured ${ }^{204} \mathrm{~Pb}$ and assuming the appropriate model of $\mathrm{Pb}$ composition of Stacey and Kramers (1975). The data reduction was performed using the SQUID/Excel macro (Ludwig, 2000) and the statistical assessments (at the 95\% confidence level) were calculated using the geochronological ISOPLOT/Excel 3.0 software of Ludwig (2003). All Concordia age errors were calculated at the $1 \sigma$ level. 


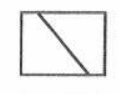

TERTIARY

$+\quad$ Pegmatite

NEOPROTEROZOIC

Santa Luzia migmatite

Igneous rocks

Biotite granite, leucogranite

Porphyritc granite,

granodiorite, monzogranite

Diorite, gabbro

Metasedimentary rocks

$\square$ Phyllite, biotite schist ( \pm garnet)

Gr. Cord. schist ( \pm and., \pm sill.), quartzite lenses

Paragneiss, marble

PALEOPROTEROZOIC

// High-grade gneiss,

minor supracrustals

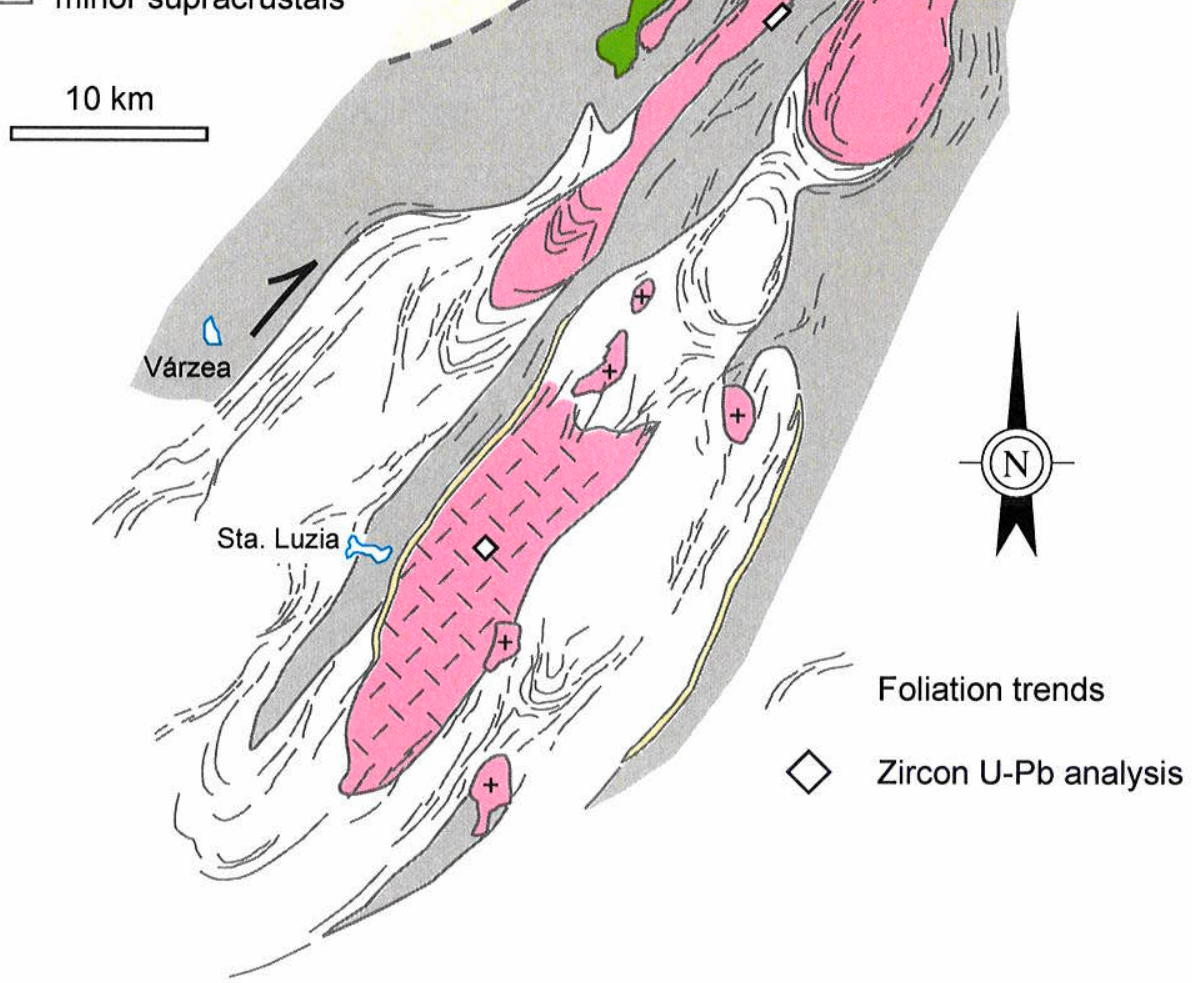

Figure 3. Geological map of the central domain of the Seridó belt. The foliation trends were outlined by using satellite and radar images. Thermobarometric geographic distribution after Lima (1987) and Souza (1996). 


\subsubsection{Results}

2.2.2.1 Totoro. The zircon crystals from the gabbro sample are euhedral to subeuhedral; they show elongated to stubbier forms. They are 100-250 $\mu \mathrm{m}$ in length and have a variable aspect ratio between $1: 1$ and $4: 1$ (typically $3: 1$ ). They are mostly colorless and inclusion-free, but fractures are pervasive in all grains. The $\mathrm{CL}$ images show well-developed sector and subordinate concentric compositional zoning. No cores were observed. Eighteen analyses were performed on different grains, but two of them were aborted (\#8.1 and \#12.1) due to the instability of the primary beam. Eight analysis lie significantly to the higher-or lower-age side of the main data cluster (\#4.1, \#11.1 to \#18.1) which provides a ${ }^{206} \mathrm{~Pb} /{ }^{238} \mathrm{U}$ concordia age of 595.3 $\pm 3.4 \mathrm{Ma}$ (Fig. 4a). Zircons separated from the dioritic sample are transparent, strongly fractured fragments with variable sizes and elongation ratios. Inclusions or cores occur locally. Most grains display magmatic, banded or slightly concentric compositional zoning; a few exhibit convoluted zonation and recrystallised inner areas. Eleven spot analyses were performed, but three (\#1.1, \#6.1, \#11.1) were very discordant and were excluded from the age estimation. The remaining eight analyses are all near or concordant, yielding a concordia age of $597.0 \pm 5.7 \mathrm{Ma}$ (Fig. 4b) that is statistically indistinguishable from that of the gabbro sample.

Zircon crystals from the porphyritic granite sample are euhedral to sub-euhedral and clear; they are 100-350 $\mu \mathrm{m}$ in length with elongation ratios ranging from 1:1 to $3: 1$. Fractures, inherited cores and oscillatory igneous zoning are common features in the grains. Twenty-one analyses were conducted on magmatic sectors from different grains; ten analyses were excluded as they were discordant or characterised by large errors in their individual analyses. The remaining eleven spot analyses (\#1.1, \#3.1, \#5.1 to \#8.1, \#10.1, \#12.1, \#14.1, \#19.1, \#21.1) were grouped to define a concordia age of $591.0 \pm 3.8 \mathrm{Ma}$ (Fig. 4c), which is considered the best estimate of the crystallisation age of the porphyritic suite.

\subsubsection{Acari. Two new U-Pb SHRIMP ages are reported here. Zircon crystals from the coarse} porphyritic granite are euhedral, $150-400 \mu \mathrm{m}$ in length and with aspect ratio ranging from $1: 1$ to 4:1. Most grains contain needle-like mineral (apatite?) and melt inclusions observed under transmitted light. The $\mathrm{CL}$ images show highly zoned crystals forming concentric patterns. Partially reabsorbed (embayed) and recrystallised sectors are also common features. Fifteen analyses were performed for different grains but only ten (\#1.1 to \#7.1, \#9.1, \#10.1, \#13.1) define a concordia age of $577.7 \pm 4.5 \mathrm{Ma}$ (Fig. 5a). If considering only the absolute age, this result is just slightly older than the concordia age calculated from the eight concordant spot analyses (\#1.1, \#4.1, \#7.1 to \#10.1,\#12.1, \#14.1) of the zircon crystals of the equigranular leucogranite sample, which provided a concordia age of $572.1 \pm 4.6 \mathrm{Ma}$ (Fig. 5b). The zircon grains of the leucogranite sample are the same size as those from the coarse porphyritic 
sample, but the former show broad to poorly defined oscillatory igneous zoning. They are sometimes rimmed by discrete U-rich overgrowths that, however, were not large enough to be analysed.
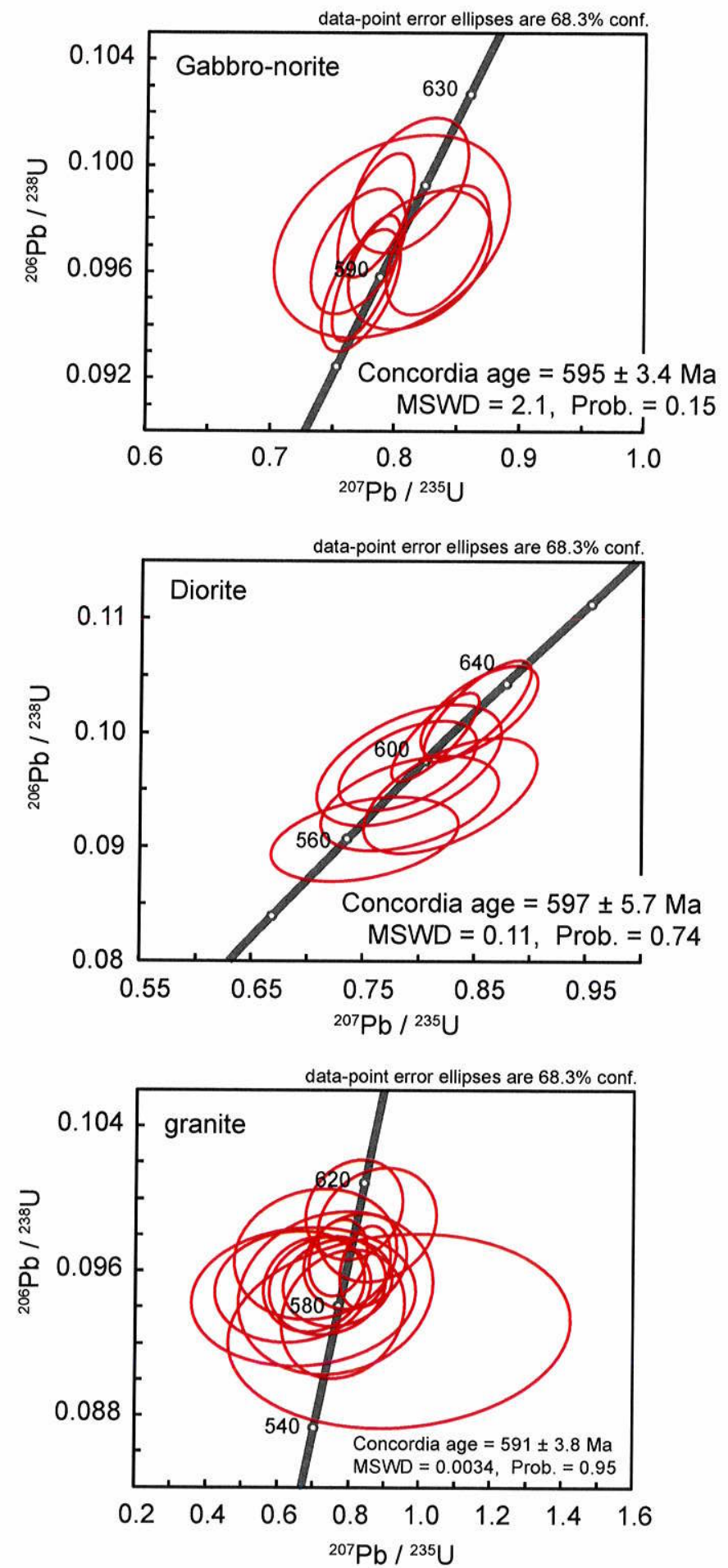

Figure 4. U-Pb concordia diagrams for the diorite $(A)$, gabbro-norite $(B)$ and porphyritic granite $(C)$ of the Totoró pluton (see analytical data in Table 1). 

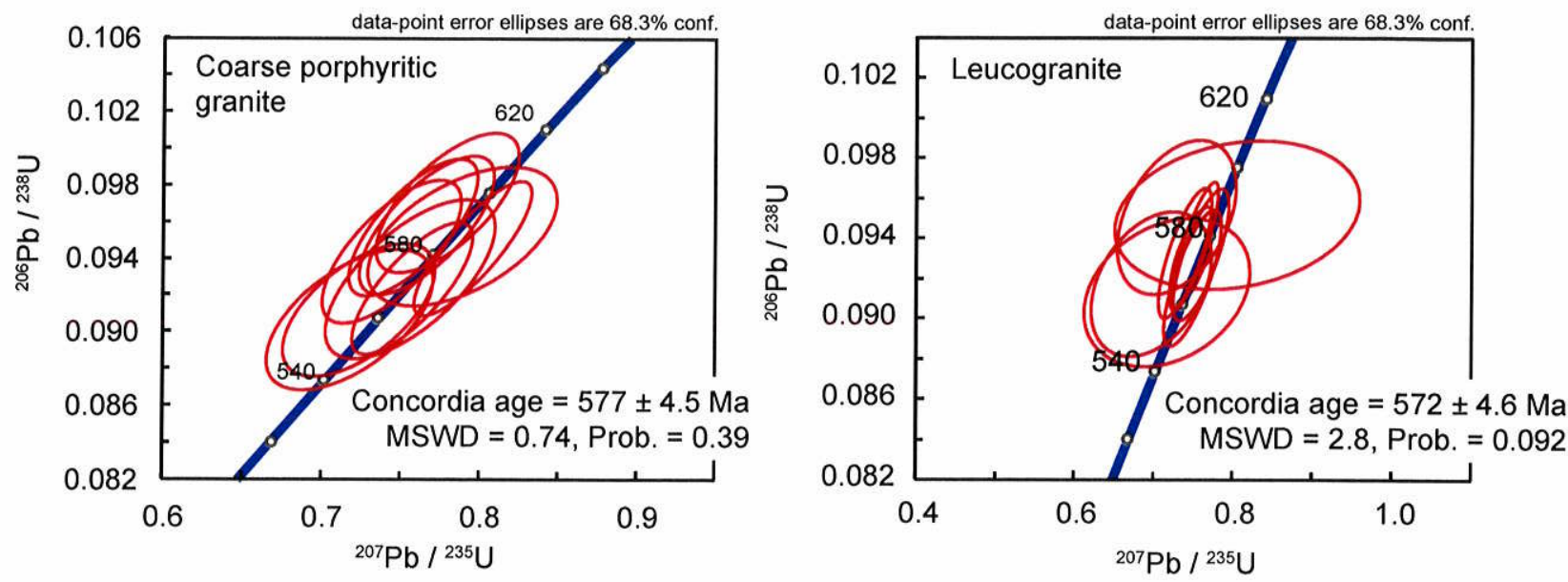

Figure 5. U-Pb concordia diagrams for the coarse porphyritic granite $(\mathrm{A})$ and equigranular leucogranite (B) of the Acari pluton.

2.2.2.3 Summary. The SHRIMP U-Pb absolute age for the sample of the porphyritic granite from the Totoró pluton, although a few million younger in age, cannot be distinguished within the uncertainty limits from those of the gabbro and diorite samples. Furthermore field evidence suggests that diorites and porphyritic granites coexisted at the magmatic stage (cf. Archanjo et. al., 2002) indicating that the mafic and felsic magmas of the Totoró pluton crystallised at $c .595$ Ma. In contrast, the temporal relationship between the Acari and Totoró plutons is now clear, the former being younger as shown by its reliable crystallisation ages at $c .575 \mathrm{Ma}$.

\subsection{The anatexite of Santa Luzia}

The anatexite of Santa Luzia consists of a dome-like structure that is $80 \mathrm{~km}^{2}$ and elongated in the NE-SW direction. It comprises a core of migmatised rocks flanked to the west and to the east, respectively, by quartzite and sillimanite schist of the Serido Group and the basement complex (Figs. 3 and 6). The structure of the host rocks consists of narrow lateral synclines recorded, respectively, by a keel of the supracrustal sequence and a tight folding of the gneissic banding. The axial plane foliation in the lateral synclines is steep dipping, while the lineations (mineral and stretching) are subhorizontal. In contrast, the migmatitic core displays magmatic structures. Internally, it varies from a nebulite including relicts of pre-existing rocks or rock structures in diffuse contacts to more homogeneous portions of equigranular leucogranite (Fig. 7a). Pegmatite sheets usually occupy the contact with the host rocks. Angular to ovalshaped enclaves of the basement rocks (banded gneiss, augen gneiss and amphibole) of variable sizes are relatively frequent. Field evidence suggests that some enclaves were partially digested by the melt (Fig. $7 \mathrm{~b}$ ) to leave a mica-rich residue hosted by the nebulite. The field and 
structural relations suggest that the Santa Luzia migmatite was emplaced and expanded to form a dome exploiting the contact between the Seridó Group and its basement rocks.

The rocks that form the Santa Luzia dome have traditionally been ascribed in the regional mapping studies to the basement complex of the Seridó belt. However, indisputable basement rocks formed by banded gneiss, granitic orthogneiss and metamorphosed mafic dykes dated in the range of 2.4 to $2.2 \mathrm{Ga}$ occur to the east of the dome (Hollanda et al., 2011). Migmatised rocks associated with leucogranite sheets and pegmatite can be traced northeastward in continuity with the Acari and Totoró plutons, which allowed us to suppose a genetic link between the intrusion of granite batholiths and melting of the underlying basement complex. The structural connections between the migmatites and granite plutons were investigated by comparing the anisotropy of magnetic susceptibility (AMS) of the Santa Luzia dome and those of the Acari and Totoró plutons which had been formerly investigated by the same technique (Archanjo et al., 2002). We include, in addition, a new zircon U-Pb age of a felsic neossome of the migmatite. This study, therefore, aims to investigate the structures and kinematic of the melted fraction of the Santa Luzia dome. We do not explore the ascent mechanisms of partially melted rocks in the crust neither the doming process in migmatitic rocks.
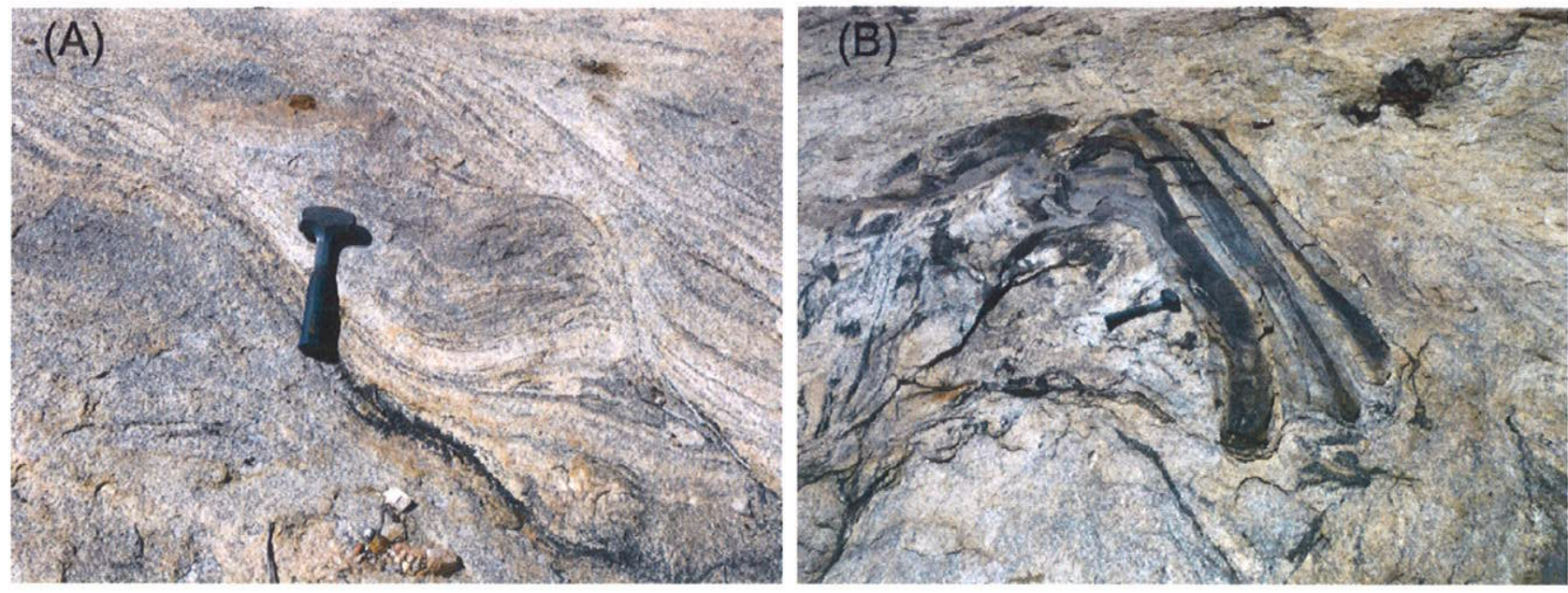

Figure 6. Santa Luzia migmatite. (A) Schlirien structure defined by biotite-rich films alternating with granitic layers (leucossome) enclosing an apparently rotated older mesossome; note a more homogeneous domain (lower left) consisting of a biotite leucogranite (site 9). (B) Angular enclave of banded gneiss partially digested by the melt (left); the rafts of the banded gneiss in the host nebulite show curved contacts, sometimes looking stirred and disrupted resembling a schollen structure (site 16). 


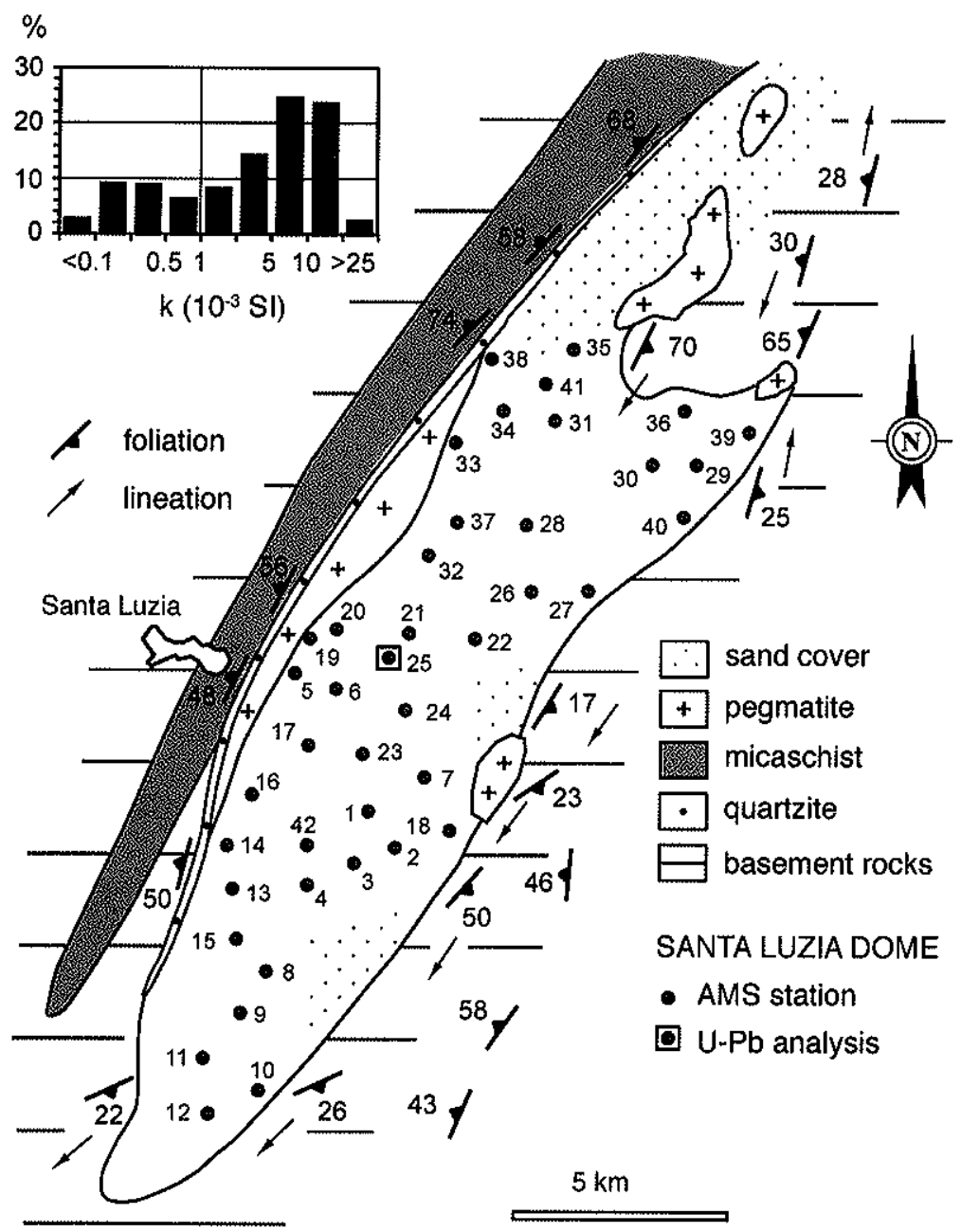

Figure 7. Simplified geological map of the Santa Luzia migmatite and distribution of AMS sites.

\subsubsection{Anisotropy of Magnetic Susceptibility}

\subsubsection{Sampling and methods}

The locations of the sites sampled for the rock magnetic studies are shown in figure 6 . At each site we extracted at least three cores of approximately $8 \mathrm{~cm}$ in length and $2.5 \mathrm{~cm}$ in diameter using a portable gasoline-powered rock drill. The cores were oriented with a magnetic compass. In the laboratory each core was cut into standard specimens that were $2.2 \mathrm{~cm}$ in length, such that the 42 sites provided 308 specimens for AMS measurements. The magnetic properties of the specimens were studied at the Laboratorio de Paleomagnetismo of the Universidade de São Paulo. Low-field AMS was determined in a Kappabridge KLY-4 device and the mean-site parameters (magnitude, directions) of the anisotropy tensor (K1>K2 $>\mathrm{K} 3$; see Table 2) were calculated by ANISOFT v. 3.2 software provided by the constructer (AGICO Ltd). The anisotropy of anhysteretic remanence (AAR) was determined in a shielded room using an 
automatic JR-6 magnetometer and an alternate field tumbling demagnetiser coupled to a device that applies a weak direct (anhysteretic) field at different positions on a specimen. The basic procedure consists of exposing the specimen in cycles of demagnetisation in an AF on the order of $100 \mathrm{mT}$, followed by anhysteretic remanence acquisition and measurement of the resulting magnetisation. In contrast to AMS which describes the specimen bulk anisotropy, AAR isolates the contribution of remanence-bearing minerals from that of the paramagnetic and/or diamagnetic phases (see Jackson, 1991). To determine the best position scheme we initially computed the AAR ellipsoid by fitting the data for 6 and 12 positions. The results showed that the tensors were well-resolved and similar to each other for both schemes, so the AAR was calculated using the 6 positions protocol.

The temperature dependence of the magnetic susceptibility $(K-T)$ was investigated from $-200^{\circ} \mathrm{C}$ to $700^{\circ} \mathrm{C}$ using a CS-3/CS-L furnace apparatus linked to the KLY-4 Kappabridge. The samples were crushed to a fine sand grain size and the $\mathrm{K}-\mathrm{T}$ was measured at each $3^{\circ} \mathrm{C}$ interval. The coercivity spectrum analysis (Dunlop, 1972) was performed by placing a specimen in a steady magnetic field that was progressively increased. Applied fields from $10 \mathrm{mT}$ up to approximately $2 \mathrm{~T}$ were imparted using a pulse magnetiser, and the isothermal remanent magnetisation (IRM) was measured in a Molspin magnetometer. Stepwise $k-T$ and IRM measurements were investigated in 12 different specimens to cover the range of magnetic susceptibility values of the migmatite. At low temperatures, $k-T$ was recorded by warming the sample to room temperature. From room temperature to $700{ }^{\circ} \mathrm{C}$ (heating cycle) and back (cooling cycle), k - T was measured in an argon environment to minimise the effects of atmospheric oxygen on the heating/cooling cycle.

\subsubsection{Magnetic susceptibility and anisotropy}

The bulk magnetic susceptibility $(\mathrm{K})$ ranges from 0.02 to $55.59 \times 10^{-3} \mathrm{SI}$ (average $=7.01$ $\mathrm{mSI}$; SD 7.76). Ferromagnetic susceptibilities (K>1 mSI) occur in $63 \%$ of the sites (Fig. 6 ) and very low susceptibilities, as low as $0.5 \mathrm{mSI}$, occur in $21 \%$ of the sites. Values of $\mathrm{K}>1 \mathrm{mSI}$ are found in the whole dome irrespective of the geographic location but sites with $\mathrm{K}<0.5 \mathrm{mSI}$ (\#5, $16,19,20$ ) occur to the west close to the contact with a pegmatite (Fig. 6). To assist the interpretations of the magnetic fabric we investigated the anisotropy directions of the AMS and AAR of representative sites with high $(\# 10, \# 6)$, moderate $(\# 18)$ and low $\mathrm{K}$ values (\#19).

a) High susceptibility and anisotropy degree sites. Specimens with a high susceptibility ( $\mathrm{K}>5$ $\mathrm{mSI}$ ) and anisotropy degree $(P \geq 1.20)$ comprise $51 \%$ of the sites. The IRM saturate above applied fields of $150 \mathrm{mT}$ indicating the remanence is carried by a soft component (Fig. $8 \mathrm{a}, \mathrm{b}$ ). 
The $k-T$ curves are very simple. They are characterised by a net Verwey transition at c. -160 ${ }^{\circ} \mathrm{C}$ and a susceptibility that vanishes almost totally above $580^{\circ} \mathrm{C}$. The cooling cycle is practically reversible indicating no new phases were formed on heating and cooling. Therefore, the IRM and $k-T$ for the sites with very high (Fig. 8a) and high (Fig. 8b) susceptibility and anisotropy are typical of a low coercive coarse (Ti-poor) magnetite. The ellipsoids that describe the AMS and AAR are similar in shape and orientation. The anisotropy of the AAR is higher than that of the AMS and the ellipsoids show oblate shapes $(T>0)$ and the respective principal directions are nearly coaxial.

b) Moderate to low susceptibility and anisotropy degree sites. Specimens with moderate susceptibility $(1<\mathrm{K}(\mathrm{mSI}) \leq 5 ; 1.10<\mathrm{P}<1.20)$ comprise $22 \%$ of the sites while those with low susceptibility $(\mathrm{K}(\mathrm{mSI})<1 \mathrm{mSI})$ comprise $27 \%$. Specimens with moderate susceptibility (Fig. $8 \mathrm{c}$ ) have $k-T$ curves quite similar to the specimens with high susceptibility, indicating that magnetite is the main carrier of the susceptibility and anisotropy. However, IRM does not saturate as shown by the smooth, but progressive increase of the remanence between 0.5 and $2.0 \mathrm{~T}$. Thus, besides a soft component, the IRM analysis indicates the presence of a high coervice (hard) component. The $k-T$ shows that the soft component must correspond to a coarse Ti-poor magnetite, while the hard component is attributed to hematite which does not saturate even for fields above $2 \mathrm{~T}$. Considering the gentle slope of the IRM above $0.5 \mathrm{~T}$ and the lack of evidence for Morin $\left(-10^{\circ} \mathrm{C}\right)$ or Néel $\left(670^{\circ} \mathrm{C}\right)$ transitions, we estimate that a small amount of hematite must occur in the sample.

IRM acquisition curves of specimens with $\mathrm{K}<0.5 \mathrm{mSI}$ show a steep initial slope and reach nearly $90 \%$ of their saturation magnetisation by $150 \mathrm{mT}$. However, the curve continues to climb and does not saturate at $1.4 \mathrm{~T}$ (Fig. $8 \mathrm{~d}$ ). The $k-T$ curve at a low temperature shows a poorly defined Verwey transition, which may be attributed to a very low content of fine magnetite grains and/or its suppression by an oxidising magnetite (Ozdemir and Dunlop, 1993). During the heating cycle, the susceptibility decreases between 280 and $320^{\circ} \mathrm{C}$ suggesting that the sample contains a magnetic sulphide (phyrrotite, greigite; $T_{C} \sim 320^{\circ} \mathrm{C}$ ). The curves also show a strong increase in susceptibility between 500 and $550{ }^{\circ} \mathrm{C}$ but this is not reproduced on cooling, indicating that new magnetic phases were formed on heating. The presence of magnetite and hematite is therefore only suggested by, respectively, the soft and hard coercive components detected in the IRM curve. 

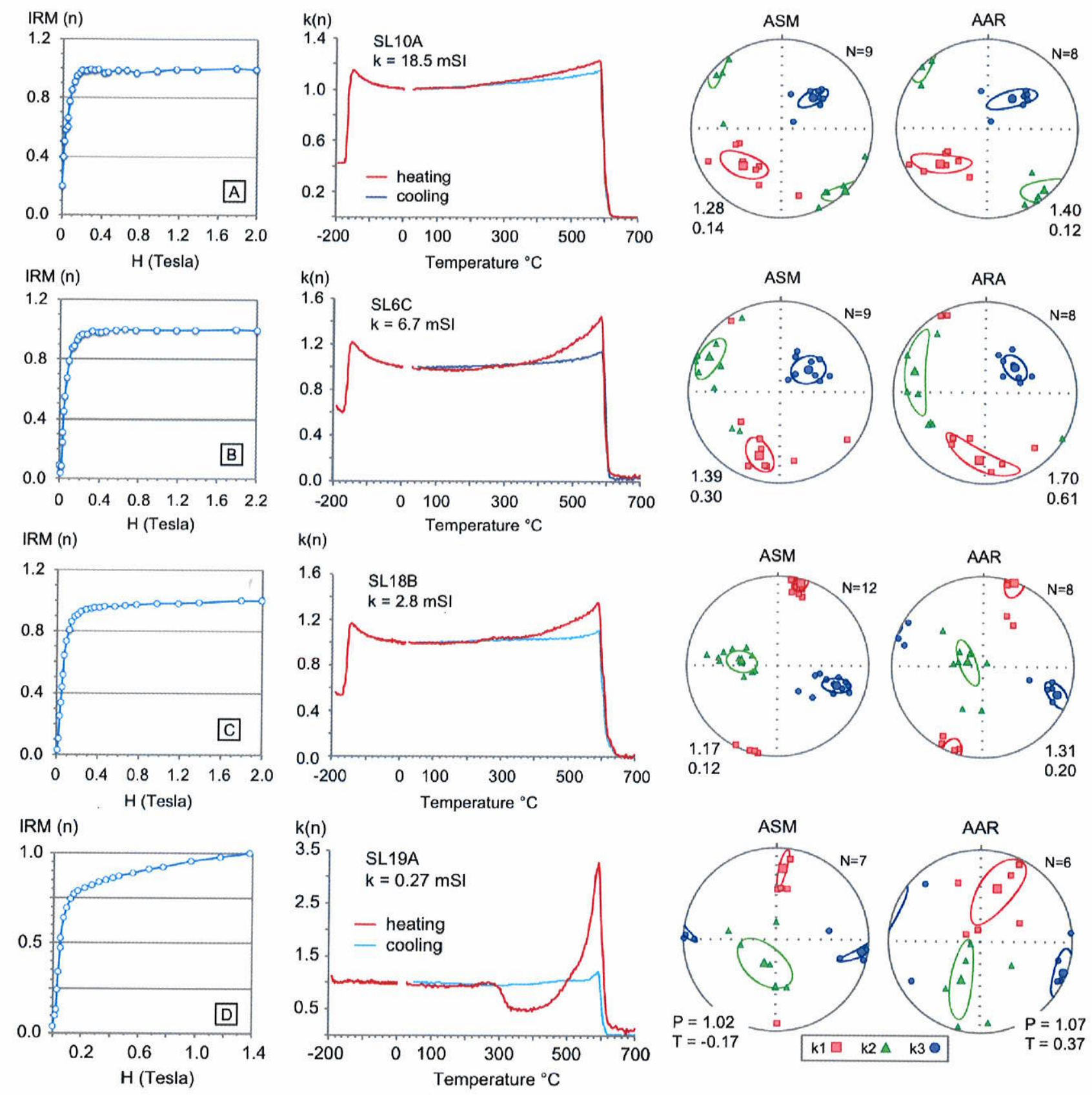

Figure 8. Isothermal remanent magnetisation (IRM) acquisition and respective susceptibility $(\mathrm{k})$ temperature (T) dependence for high (A, B), moderate (C) and low (D) magnetic susceptibility for representative specimens of the Santa Luzia dome. The AMS and AAR principal directions (k1 $\geq k 2 \geq k 3)$ of the corresponding sites reveal a good concordance between the fabric elements ( $N$, number of measured specimens). Lower-hemisphere, Schmidt stereonet.

The principal directions of the AMS and AAR share a similar orientation even for the site displaying contrasting ellipsoid shapes (Fig. 8c, d). Like those recorded in sites with high susceptibility, the anisotropy degree is higher in the AAR than the AMS. Variations in the magnitude of the anisotropy directions and, therefore, in the ellipsoid shape (Fig. 8d) can be attributed to the increasing contribution of paramagnetic silicates to the bulk susceptibility as the content of the ferromagnetic fraction decreases down to $0.1 \%$ (Tarling and Hrouda, 1993). 


\subsubsection{Anisotropy of susceptibility directions}

The magnetic fabric, represented in figure 9 by the mean-site lineation (K1) and foliation (plane normal to $\mathrm{K} 3$ ), has a relatively uniform orientation. The magnetic lineation plunges gently to the NNE or SSW and the foliation generally dips to the NW. The magnetic fabric is slightly oblique with regards to the mean NE-trending elongation of the dome, a feature that has been also observed further north in the Acari pluton (Archanjo et al., 2002). We also observe that the magnetic foliation does not reproduce the opposite dip of the contacts in the flanks of the dome, which suggest that the AMS records the latest incremental deformations that have affected the melt.

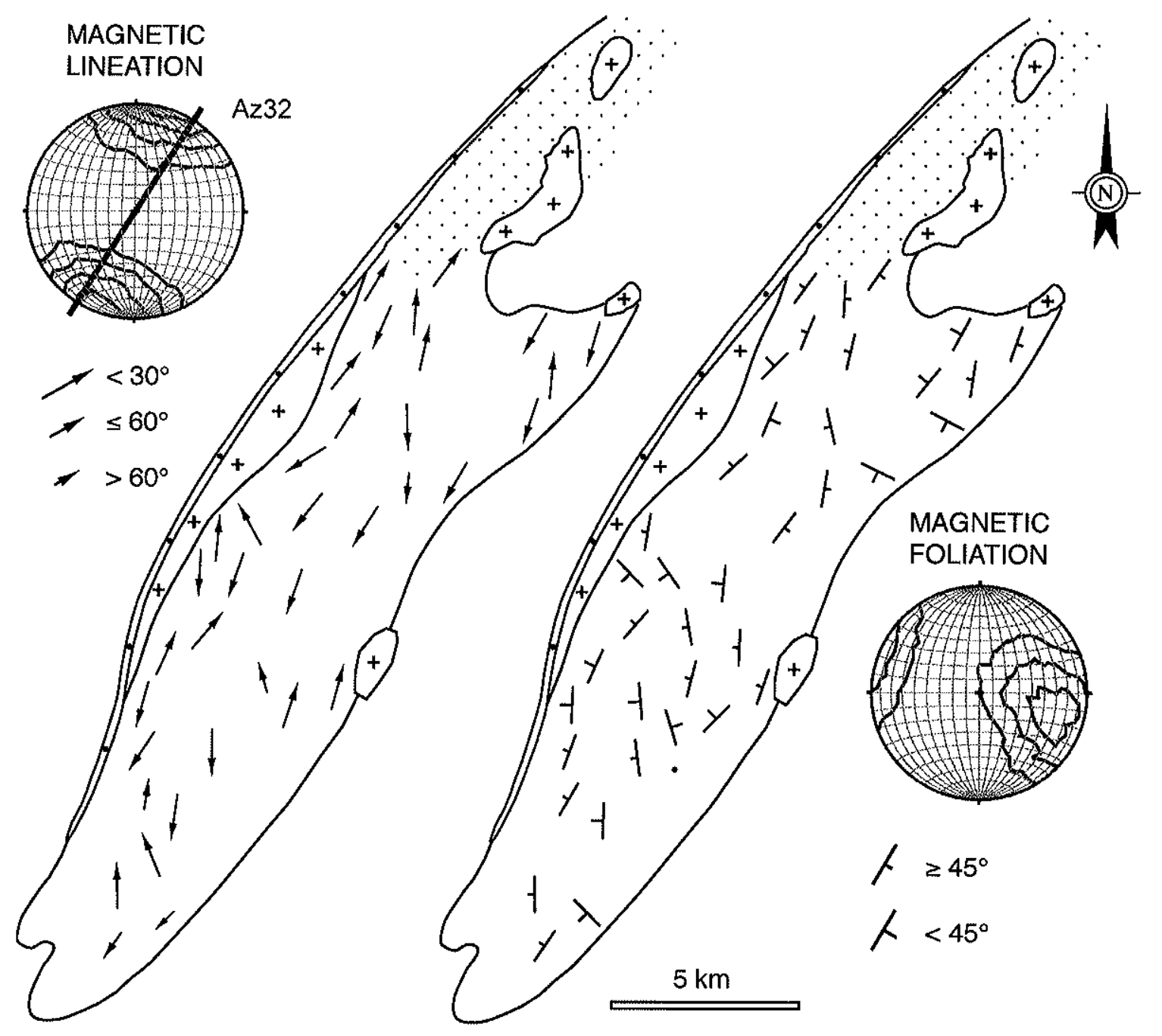

Figure 9. Magnetic fabric (foliation, lineation) of the migmatitic dome. Density (Kamb) contours, lower hemisphere; the grey line correspond to the elongation direction of the dome. 
We collected a sample from a nebulite located in the centre of the dome (see location on Fig. 6). It is composed of a leucocratic rock containing "gosh" layers of alternate lighter and darker material. The hand sample consists of a homogeneous, coarse-grained and equigranular biotite granitic nebulite. The zircon crystals are euhedral and many display dipyramidal terminations. Their lengths are of 50-200 $\mu \mathrm{m}$ with an aspect ratio between $1: 1$ and $3: 1$. In transmitted light they show xenocrystic cores and large dark areas that appear to be metamitised. Many grains are rimmed by zircon overgrowths. In $\mathrm{CL}$ images (Fig. 10) these overgrowths form dark (U-rich), slightly zoned rims measuring about 5-30 $\mu \mathrm{m}$ in width that are probably metamorphic in origin.

Sixteen analyses of the dark high $U$ rims yielded slightly reverse ages with a weighted mean ${ }^{206} \mathrm{~Pb} /{ }^{238} \mathrm{U}$ age of $573.2 \pm 3.4 \mathrm{Ma}$ (Fig. 11). Eight analyses of the zircon cores resulted in a concordia upper intercept age of $2203 \pm 17 \mathrm{Ma}$ that is consistent with ages we have determined from nearby basement exposures (Hollanda et al., 2011). When plotted together these two groups align quite well along a discordia line with a lower intercept at $575.1 \pm 3.4 \mathrm{Ma}$. This younger age obtained on the $U$-rich rims is interpreted as the crystallisation age of the granitic neossome resulting from the HT event that melted the basement complex.

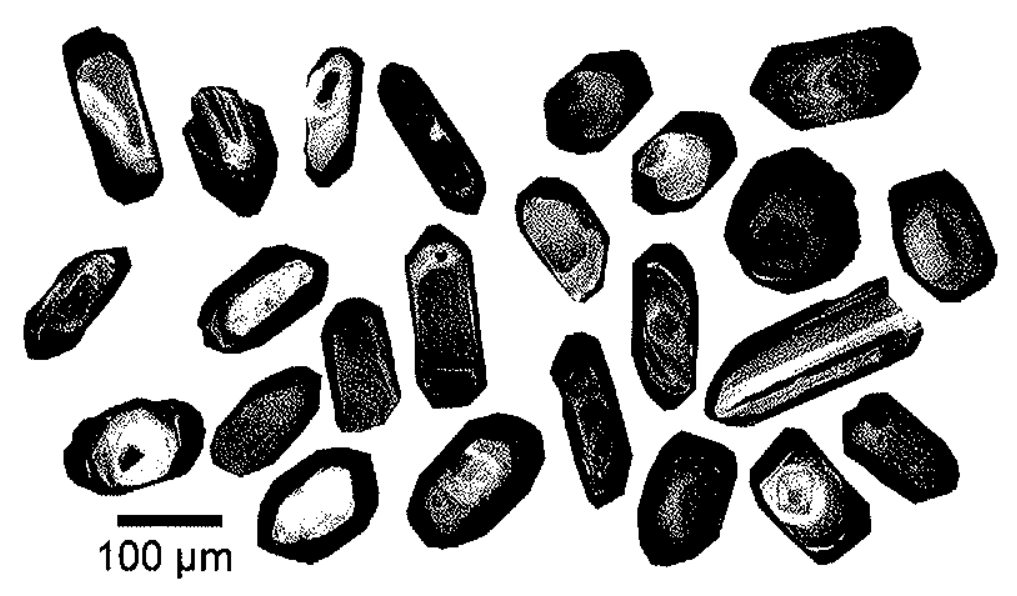

Figure 10. Cathodoluminescence image of selected zircons from the Santa Luzia migmatite. The grains usually show an inner concentric zoning rimmed by a dark, U-rich overgrowths.

\section{DISCUSSION}

\subsection{Significance of magnetic fabrics in the migmatite}

The AMS sampling of the Santa Luzia dome was restricted to the more homogenous granitic portions of the migmatite where a magmatic microstructure can be recognised. Thus, the AMS properties of the samples are analogous to the common granitoids in that their general 
principles are described in Bouchez (1997). Rock magnetic studies showed that magnetite and minor hematite are the main mineral phases responsible for the magnetic susceptibility and $c .-160{ }^{\circ} \mathrm{C}$ and the net drop of susceptibility on heating near $580^{\circ} \mathrm{C}$. Hematite was inferred by the presence of a highly coercive fraction for samples that do not saturate up to induced fields of $2 \mathrm{~T}$ and, in some $k-T$ runs, by the progressive decreasing of $\mathrm{k}$ after $570{ }^{\circ} \mathrm{C}$ until it completely disappears at $\mathrm{C.} 700{ }^{\circ} \mathrm{C}$ (not shown in Fig. 8). These magnetic characteristics are consistent with hematite which has a Néel temperature of $670{ }^{\circ} \mathrm{C}$. Moreover, some samples of the low susceptibility group may contain traces of a magnetic sulphide as suggested by the small drop in susceptibility on heating at c. $300{ }^{\circ} \mathrm{C}$. Alternatively, the decreasing of the susceptibility magnitude at c. $300{ }^{\circ} \mathrm{C}$ could correspond to mineral alteration during the heating cycle as evidenced the strong increase of $k$ just before the Curie temperature of magnetite.
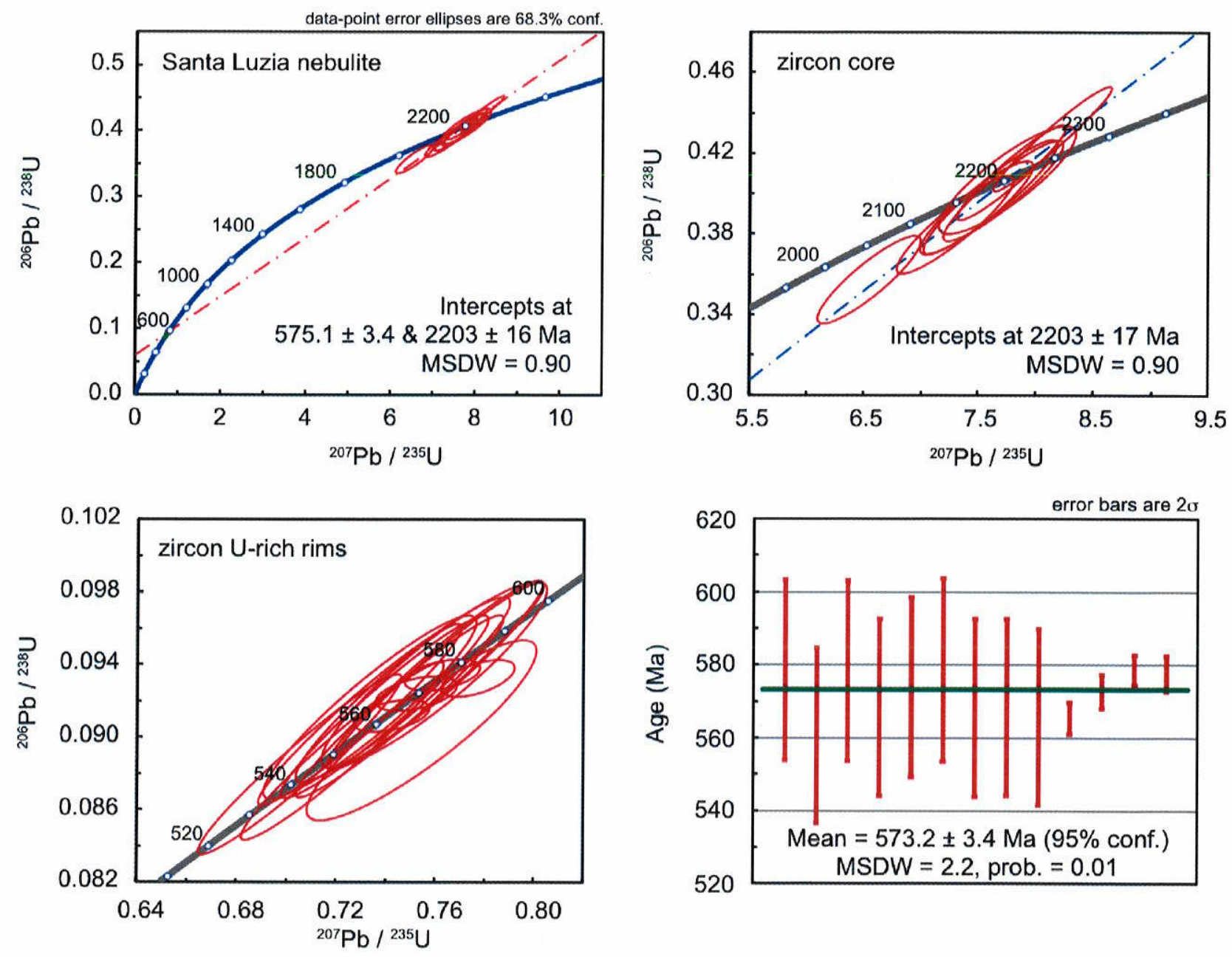

Figure 11. U-Pb concordia diagram for a granitic nebulite of the Santa Luzia dome detailing the analysis in the zircons cores (upper intercept) and in the U-rich overgrowths around the zircon margins (lower intercept). The zircon overgrowths yields a ${ }^{207} \mathrm{~Pb}$-corrected ${ }^{206} \mathrm{~Pb} /{ }^{238} \mathrm{U}$ mean weighted age of $573.2 \pm 3.4$ Ma. 
Evidence for magnetite is also seen in the AAR studies as a fabric induced by an anhysteretic induction is only recorded in the phases that retain a remanence, which excludes dia- and paramagnetic minerals. The results show a very good correlation between the orientations of the principal directions of the AAR and ASM irrespective of the magnitude of the susceptibility. Moreover, at sites with moderate to high susceptibility ( $\mathrm{K}>1 \mathrm{mSI}$ ), there is a good correspondence between the symmetry of the AAR and AMS ellipsoids. Differences in the ellipsoid symmetry were found in samples with low susceptibility values. This can be attributed to the increasing importance of paramagnetic silicates in the susceptibility and anisotropy as the susceptibility declines down to $10^{-3} \mathrm{SI}$. For a very low susceptibility, say less than $0.30 \mathrm{mSI}$, the contribution to the AMS of paramagnetic silicates becomes dominant and the ferrimagnetic grains, if any are available, occur as submicroscopic inclusions usually hosted in silicates (Rochette, 1988; Borradaile and Werner, 1994). The different grain sizes of magnetite are also evidenced in the thermomagnetic curves. Well-defined Verwey transitions at c. $-160{ }^{\circ} \mathrm{C}$ and net Curie temperatures of c. $580^{\circ} \mathrm{C}$ are typical of a coarse multidomain Fe-rich grain, while poorlydefined Verwey transitions are attributed to fine and/or oxidising grains (Ozdemir and Dunlop, 1993). In our samples, however, the finest grains are not small enough to develop fabric inversions produced by single-domain grains as indicated at site SL19 (Fig. 8d) which, despite of differences between the AAR and AMS ellipsoid shapes, shows a good correspondence between their principal directions.

In summary, we conclude that the AMS of Santa Luzia dome is dominated by shape anisotropy of magnetite. Some hematite, magnetic sulphide and biotite contribute locally to the bulk AMS but they do not substantially modify the fabric produced by the magnetite. The resulting magnetic fabric is well-organized in the whole dome, but symptomatically it does not mimic the shape of the dome. This is evident in the magnetic foliation that does not reproduce the dip to the east of the eastern dome margin as well as the mean lineation direction oblique to the dome elongation. These results imply that the: (i) AMS records the latest magmatic deformation events before the full crystallisation of the neossome, and (ii) magnetic fabrics can be interpreted as syntectonic to a dextral HT event in that the lineation and foliation tend to align in the direction of the principal flattening plane of the regional strain ellipsoid (Fig. 12). The magnetic fabric of the Santa Luzia migmatite, therefore, is similar to that recorded in the Acari pluton.

\subsection{Timing of the HT deformational event}

The new SHRIMP U-Pb zircon ages of a porphyritic granite and a leucogranite of the Acari pluton and the granitic leucossome of the Santa Luzia migmatite allow us to constrain the 
timing of the HT deformation of the Serido belt at c. $575 \mathrm{Ma}$. This event was responsible for melting the Caicó Complex to form migmatite domes that, like in Santa Luzia, host large enclaves of the Paleoproterozoic basement and zircon xenocryts rimmed by overgrowths of Neoproterozoic age. Furthermore, the melts and the HT/LP metamorphism coexisted with a general dextral shear deformation that produced regional fan-like foliations including beltparallel stretching lineations (Archanjo and Bouchez, 1991; Araújo et al., 2001). SHRIMP U-Pb zircon ages of the porphyritic granite and leucogranite are consistent with the age of the Acari diorite yielded by conventional U-Pb methods (Leterrier et al., 1994). However, the younger U$\mathrm{Pb}$ ages calculated from the zircon and monazite of samples from the same granite are here attributed to the resetting of the isotopic system by a newer thermal episode possibly related to the intrusion of the Seridó pegmatitic province (Araújo et al., 2001; Baumgartner et al., 2006). The HT metamorphism and melting of the basement dated between 578 and $574 \mathrm{Ma}$ have also been described to the east of the Seridó belt. These ages were recorded by Sm-Nd on garnetwhole rock from a granitic leucossome and on garnet bearing alkaline granites emplaced in an extensional setting (Souza et al., 2006).

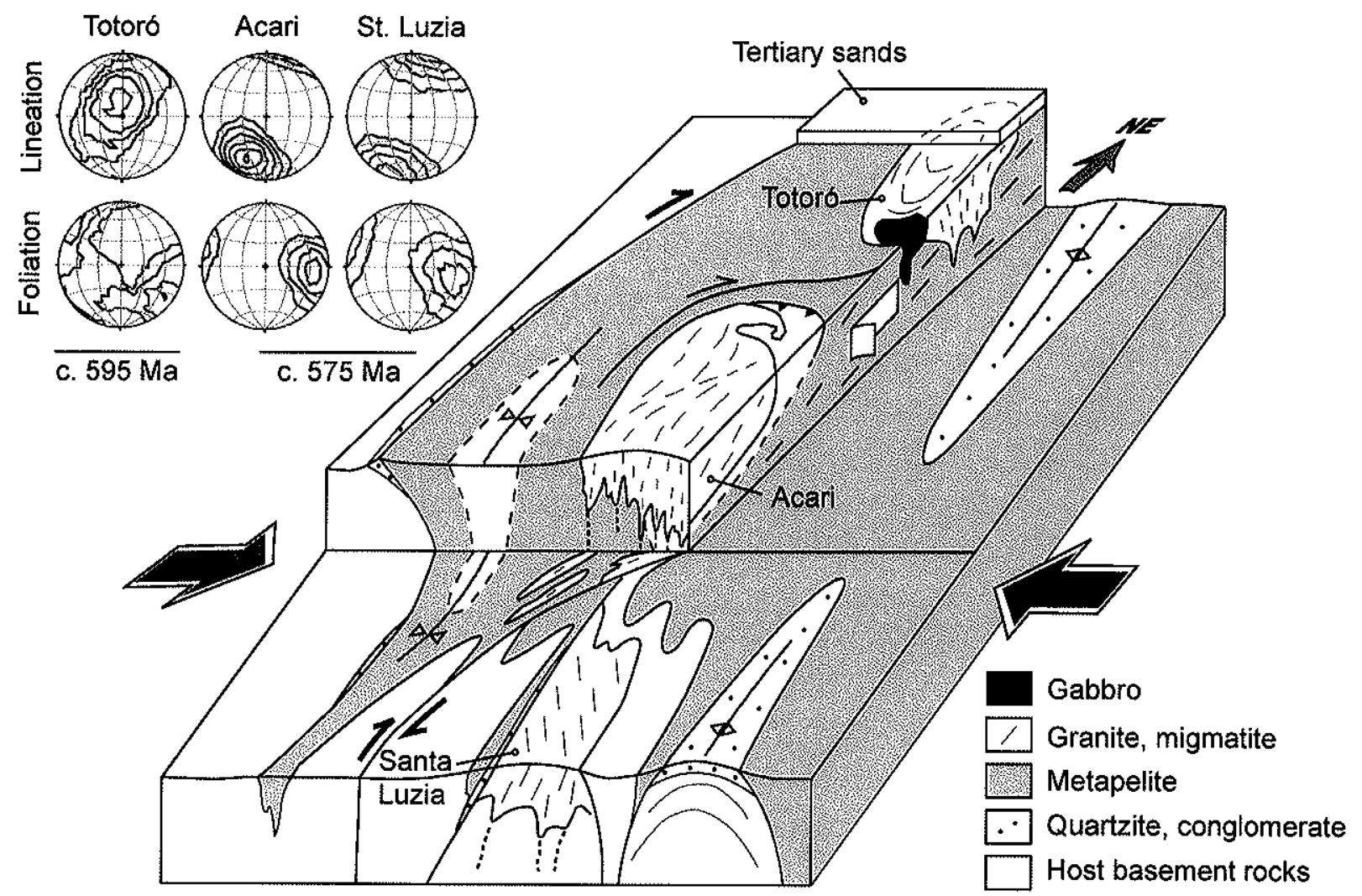

Figure 12. Schematic block-diagram illustrating the relationship between the fabric of the magmatic rocks (dashed pattern) and the structure of the central domain of the Serido belt. The block containing the Acari and Totoro plutons is at the same topographic level than that of Santa Luzia, being shown uplifted to illustrate the inferred deep structure. It combines E-W shortening and NE-trending dextral strike slip shearing synchronous with the emplacement of the Acari pluton and Santa Luzia migmatitic dome. The significance of the magnetic fabrics (lineation and foliation) of the Totoro and Acari plutons are discussed in Archanjo et al. (2002). Density (Kamb) contour in the lower hemisphere stereonet. 
SHRIMP U-Pb concordia ages between 597 and 591 Ma were given by, respectively, the mafic and felsic intrusions that constitute the Totoró pluton. At first glance, we could consider the felsic and mafic rocks to have been formed by separate magmatic pulses but field evidence indicates that the diorites and granites coexisted at the magmatic stage. Therefore, if we assume that the pluton was built from a single magmatic event and take into account the analytical errors of the individual analyses, we estimate the crystallisation age of mafic and felsic rocks at c. $595 \mathrm{Ma}$. By comparing the results from the Totoró with Acari plutons and Santa Luzia migmatite and even considering the errors from the individual analyses of the samples, it becomes evident that the Totoró magmatism is approximately $15 \mathrm{~m}$.y. older than the HT tectonothermal event recorded in the central domain of the Seridó belt. Further evidence for a distinct evolution of the Totoró pluton come from the magnetic fabric as its steep plunging lineation contrasts with that of the Acari pluton and Santa Luzia migmatite (Fig. 12). The geochronological and structural evidence indicate, therefore, that the Totoró type magmatism precedes the HT-transpression of the Seridó belt. An older mafic magmatism has been identified in a few places in the Seridó-Jaguaribe domain, such as a leuconorite dated by the U$\mathrm{Pb}$ method at $599 \pm 16 \mathrm{Ma}$ (Dantas, 1997) and the Riachão gabbro at $588 \pm 6 \mathrm{Ma}$ (Guimarães et al., 2009). Similar ages have been found for carbonatites and alkaline granites in the PanAfrican Dahomeyide (West Africa) and these have been linked to an extensional episode following the collision of the West African craton (Attoh et al., 2007).

Lima et al. (1989) describe pyroxene hornfels in the contact of the Totoró gabbro-norite with the host mica schist and in a $50 \mathrm{~m}^{2}$ wide pelitic enclave within the mafic rock. In hornfelsbearing garnet-biotite-cordierite assemblages they analysed the exchange reactions of $\mathrm{Fe}-\mathrm{Mg}$ to estimate the equilibrium reactions at temperatures in the range of $580-700{ }^{\circ} \mathrm{C}$ and pressures of 4 - 6 kbar. These results do not differ from the thermobarometric conditions calculated in the host rocks of the Acari pluton (Lima, 1987; Souza, 1996), allowing us to propose that the ionic exchange reactions of the Totoró hornfels were reset by the late HT transpressive event at $c$. $575 \mathrm{Ma}$. An important consequence of the thermobarometric data is that the HT mineral assemblages equilibrated at relatively shallow depths, possibly after suturing the Nigeria and Borborema shields in West Gondwana at $600 \mathrm{Ma}$.

\subsection{Implications for the connections with the Nigeria shield}

The Igarra and llesha schist belts of southern Nigeria share a similar structural history as that described in the Seridó - Jaguaribe domain (Arthaud et al., 2008; Dada, 2008). Metamorphic assemblages in the Igarra metapelites comprise andalusite-staurolite-garnet equilibrated at temperatures of $550 \pm 50^{\circ} \mathrm{C}$ and pressures of c. 3 kbar (Omitogun et al., 1991). 
In the llesha schist belt the metamorphic assemblages also include sillimanite with peak metamorphic conditions calculated at $590 \pm 20^{\circ} \mathrm{C}$ at C. $5 \mathrm{kbar}$, followed retrogression to $550{ }^{\circ} \mathrm{C}$ and $3 \mathrm{kbar}$ (Zhe and Holness, 2003). Both in Igarra and llesha, the HT/LP metamorphism was coeval with $\mathrm{N}$-trending dextral strike-slip shear zones.

In a pre-drift reconstruction a close match between the Igarra-Seridó and Senador Pompeu/Orós-Ifewara geological domains becomes evident. The Orós belt (see Fig. 2) is situated near the dextral Senador Pompeu shear zone. It consists of a rift sequence including an aluminous schist, quartzite lenses and local $\mathrm{Ca}$ - to Mg-rich carbonate rocks overlaying acid metavolcanics. The metamorphism varies from greenschist facies to amphibolite facies with andalusite-staurolite-garnet assemblages to increases up to HT-amphibolite and granulite approaching the Atlantic coast (Arthaud et al., 2008). Barrovian-type metamorphism prevails to the west of the Senador Pompeu shear zone. However, there are important differences between the geology of the Orós and the Neoproterozoic Seridó belt. Firstly, the Orós volcanism occurred in the Late Paleoproterozoic (Sá, 1991) and its rift deposits include magnesite layers and possibly gypsum, which is suggestive of an evaporitic environment (Parente at al., 2004). Orós-type sequences have not been described until now in southern Nigeria and, evidently, the search for similar rock associations is critical to establish fine-scale geological correlations across the Atlantic.

\section{CONCLUSION}

Large areas situated in the Borborema Province to the north of the Patos shear zone and in south Nigeria comprising the Igarra and llesha schist belts were metamorphosed under a high temperature/ low pressure regime. Andalusite and garnet are common index mineral in pelitic rocks on both sides of the Atlantic, and the Serido schist belt in the Brazilian side include in addition syn-kinematic cordierite-sillimanite assemblages usually forming aureoles around granite plutons. The timing of the emplacement of such plutons and the migmatisation of basement rocks are now constrained by the U-Pb (SHRIMP) ages determined in the magmatic zoning sectors of zircons from the Acari granite and in the metamorphic overgrowths rimming older zircons from a felsic neossome of the Santa Luzia migmatite. Coarse porphyritic granites and leucogranites from the Acari samples provided crystallisation ages between $577 \mathrm{Ma}$ and 572, while dark U-rich overgrowths from the Santa Luzia sample yielded a concordant lower intercept age of $575 \mathrm{Ma}$. However, the errors of the analysis of the zircons from the granite and migmatite overlap ( $1 \sigma$ level) to indicate that the respective ages are indistinguishable from each other. The AMS of the Santa Luzia anatetic dome show a relatively simple organisation in that foliations dip mostly to the SW and lineations align slightly oblique with respect to the dome 
elongation. A similar fabric pattern reflecting a general dextral NE-trending transpression has been previously described in the Acari pluton. Therefore, the U-Pb (SHRIMP) ages and the AMS results combine to fix the HT/LP transpressional event of the Seridó belt at c. $575 \mathrm{Ma}$. This thermotectonic episode succeeds an older bimodal magmatism represented in the Serido belt by the Totoro pluton. The U-Pb zircon data from samples collected from different igneous units (diorite, gabbro-norite and porphyritic granite) yielded reliable ages in the range from 597 to 591 Ma. Assuming that the Totoró pluton was built in a single magmatic pulse, as supported by field evidence of mixing and mingling between dioritic and granitic magmas, we estimate that the crystallisation of the pluton would have occurred at c. $595 \mathrm{Ma}$. The geological significance of such a pre-tectonic magmatism and the timing of the HT-metamorphism in the Igarra and llesha schist belts are unknown. However, similar lithologies and thermobarometric conditions place these schist belts as a first order element in searching for across-Atlantic geological correlations.

\section{Acknowledegments}

Carlos J. Archanjo and Luis G. Viegas thank Fundação de Amparo a Pesquisa do Estado de São Paulo (FAPESP) for finantial support (grants 2010/50060-1 and 2009/17537-1). We also wish to thank Sérgio Neves and an anonymous reviewer who provided useful corrections which improved the presentation of our work. 
Tabela 1. Summary of SHRIMP U-Pb zircon data for Acari and Totoró plutons and Santa Luzia leucogranite.

\begin{tabular}{|c|c|c|c|c|c|c|c|c|c|c|c|c|c|c|c|c|c|}
\hline \multirow{2}{*}{$\begin{array}{r}\begin{array}{c}\text { Grain } \\
\text { spot \# }\end{array} \\
\text { Acari porp }\end{array}$} & \multirow{2}{*}{$\begin{array}{c}\begin{array}{c}\% \\
{ }^{206} \mathrm{~Pb}_{\mathrm{c}}\end{array} \\
\text { ritic gran }\end{array}$} & \multirow{2}{*}{$\begin{array}{l}\underset{\text { [ppm] }}{U} \\
\text { iite }\end{array}$} & \multirow[t]{2}{*}{$\begin{array}{c}\text { Th } \\
\text { [ppm] }\end{array}$} & \multirow[t]{2}{*}{${ }^{232} \mathrm{Th} /{ }^{238} \mathrm{U}$} & \multirow[t]{2}{*}{$\begin{array}{l}{ }^{206} \mathrm{~Pb}^{*} \\
\text { [ppm] }\end{array}$} & \multicolumn{2}{|c|}{$\begin{array}{c}{ }^{206} \mathrm{~Pb} /{ }^{238} \mathrm{U} \\
\text { age }\end{array}$} & \multicolumn{2}{|c|}{$\begin{array}{c}{ }^{207} \mathrm{~Pb} /{ }^{206} \mathrm{~Pb} \\
\text { age }\end{array}$} & \multirow[t]{2}{*}{$\%$ disc } & \multirow[t]{2}{*}{${ }^{207} \mathrm{~Pb}^{\star} /{ }^{206} \mathrm{~Pb}^{\star}$} & \multirow[t]{2}{*}{ $\pm \%$} & \multirow[t]{2}{*}{${ }^{207} \mathrm{~Pb}^{\star} /{ }^{235} \mathrm{U}$} & \multirow[t]{2}{*}{ $\pm \%$} & \multirow[t]{2}{*}{${ }^{206} \mathrm{~Pb}^{\star} /{ }^{238} \mathrm{U}$} & \multirow[t]{2}{*}{ $\pm \%$} & \multirow[t]{2}{*}{ err corr } \\
\hline & & & & & & & & & & & & & & & & & \\
\hline 1.1 & 0.68 & 559 & 226 & 0.42 & 46.3 & 590 & \pm 15 & 531 & \pm 57 & -11 & 0.0580 & 2.6 & 0.7665 & 3.7 & 0.0958 & 2.6 & .7097 \\
\hline 2.1 & 0.58 & 461 & 145 & 0.32 & 37.6 & 581 & \pm 15 & 500 & \pm 61 & -16 & 0.0572 & 2.8 & 0.7444 & 3.9 & 0.0944 & 2.7 & .7008 \\
\hline 3.1 & 0.36 & 814 & 461 & 0.59 & 66.3 & 583 & \pm 14 & 641 & \pm 37 & 9 & 0.0610 & 1.7 & 0.7959 & 3.1 & 0.0946 & 2.6 & .8295 \\
\hline 4.1 & 1.06 & 370 & 692 & 1.93 & 30.6 & 586 & \pm 15 & 608 & \pm 92 & 4 & 0.0601 & 4.3 & 0.7892 & 5.0 & 0.0952 & 2.6 & .5244 \\
\hline 5.1 & 0.50 & 610 & 583 & 0.99 & 48.6 & 570 & \pm 14 & 584 & \pm 46 & 2 & 0.0595 & 2.1 & 0.7576 & 3.3 & 0.0924 & 2.6 & .7717 \\
\hline 6.1 & 0.97 & 676 & 272 & 0.42 & 56.9 & 597 & \pm 15 & 540 & \pm 62 & -11 & 0.0583 & 2.8 & 0.7797 & 3.8 & 0.0970 & 2.6 & .6758 \\
\hline 7.1 & 0.86 & 351 & 268 & 0.79 & 27.7 & 563 & \pm 14 & 513 & \pm 77 & -10 & 0.0576 & 3.5 & 0.7239 & 4.4 & 0.0912 & 2.6 & .5976 \\
\hline 8.1 & 2.09 & 106 & 86 & 0.84 & 9.0 & 595 & \pm 17 & 611 & \pm 230 & 3 & 0.0602 & 10.7 & 0.8026 & 11.1 & 0.0967 & 2.9 & .2663 \\
\hline 9.1 & 0.90 & 326 & 662 & 2.10 & 25.6 & 560 & \pm 15 & 508 & \pm 87 & -10 & 0.0574 & 4.0 & 0.7182 & 4.8 & 0.0907 & 2.8 & .5764 \\
\hline 10.1 & 0.75 & 253 & 168 & 0.69 & 20.3 & 573 & \pm 17 & 569 & \pm 77 & -1 & 0.0590 & 3.5 & 0.7562 & 4.7 & 0.0929 & 3.1 & .6591 \\
\hline 11.1 & 0.50 & 1269 & 545 & 0.44 & 111.3 & 624 & \pm 15 & 523 & \pm 38 & -19 & 0.0578 & 1.7 & 0.8100 & 3.1 & 0.1016 & 2.6 & .8256 \\
\hline 12.1 & 3.19 & 105 & 109 & 1.08 & 10.0 & 659 & \pm 28 & 170 & \pm 351 & -287 & 0.0495 & 15.0 & 0.7347 & 15.7 & 0.1077 & 4.5 & .2882 \\
\hline 13.1 & 0.53 & 797 & 382 & 0.50 & 65.8 & 589 & \pm 15 & 509 & \pm 54 & -16 & 0.0574 & 2.4 & 0.7580 & 3.6 & 0.0957 & 2.6 & .7258 \\
\hline 14.1 & 0.30 & 1013 & 788 & 0.80 & 92.7 & 651 & \pm 16 & 558 & \pm 32 & -17 & 0.0588 & 1.5 & 0.8607 & 3.0 & 0.1063 & 2.6 & .8662 \\
\hline 15.1 & 1.02 & 366 & 394 & 1.11 & 31.9 & 616 & \pm 16 & 448 & \pm 101 & -38 & 0.0559 & 4.6 & 0.7727 & 5.3 & 0.1003 & 2.6 & .5014 \\
\hline \multicolumn{18}{|c|}{ Acari fine-grained granite } \\
\hline 1.1 & 0.33 & 227 & 185 & 0.84 & 18.2 & 575 & \pm 13 & 513 & \pm 43 & -12 & 0.0575 & 1.9 & 0.7404 & 3.0 & 0.0933 & 2.3 & .7640 \\
\hline 2.1 & 3.47 & 47 & 54 & 1.18 & 3.7 & 551 & \pm 18 & -221 & \pm 469 & 349 & 0.0421 & 18.6 & 0.5175 & 18.9 & 0.0892 & 3.3 & .1755 \\
\hline 3.1 & 1.24 & 70 & 99 & 1.46 & 5.5 & 557 & \pm 20 & 325 & \pm 168 & -72 & 0.0529 & 7.4 & 0.6590 & 8.3 & 0.0903 & 3.7 & .4495 \\
\hline 4.1 & 1.05 & 61 & 77 & 1.32 & 5.0 & 586 & \pm 15 & 439 & \pm 139 & -34 & 0.0557 & 6.2 & 0.7296 & 6.8 & 0.0951 & 2.7 & .3930 \\
\hline 5.1 & 0.96 & 95 & 136 & 1.47 & 6.7 & 500 & \pm 14 & 303 & \pm 155 & -65 & 0.0524 & 6.8 & 0.5833 & 7.4 & 0.0807 & 2.8 & .3810 \\
\hline 6.1 & 0.69 & 133 & 143 & 1.11 & 10.9 & 584 & \pm 15 & 368 & \pm 85 & -59 & 0.0539 & 3.8 & 0.7053 & 4.6 & 0.0948 & 2.6 & .5690 \\
\hline 7.1 & 1.14 & 63 & 73 & 1.20 & 5.0 & 566 & \pm 14 & 418 & \pm 149 & -35 & 0.0552 & 6.7 & 0.6978 & 7.2 & 0.0918 & 2.6 & .3617 \\
\hline 8.1 & 0.28 & 202 & 217 & 1.11 & 16.1 & 568 & \pm 13 & 569 & \pm 45 & 0 & 0.0591 & 2.1 & 0.7497 & 3.2 & 0.0921 & 2.4 & .7639 \\
\hline 9.1 & 3.31 & 89 & 130 & 1.52 & 7.5 & 586 & \pm 14 & 652 & \pm 265 & 10 & 0.0614 & 12.4 & 0.8053 & 12.6 & 0.0952 & 2.6 & .2031 \\
\hline 10.1 & 0.24 & 452 & 178 & 0.41 & 36.4 & 577 & \pm 13 & 539 & \pm 31 & -7 & 0.0582 & 1.4 & 0.7521 & 2.7 & 0.0936 & 2.3 & .8499 \\
\hline 11.1 & 0.17 & 1008 & 1193 & 1.22 & 107.3 & 752 & \pm 16 & 580 & \pm 14 & -30 & 0.0594 & 0.7 & 1.0127 & 2.4 & 0.1237 & 2.3 & .9595 \\
\hline 12.1 & 0.39 & 183 & 237 & 1.34 & 14.7 & 575 & \pm 13 & 573 & \pm 44 & 0 & 0.0592 & 2.0 & 0.7604 & 3.1 & 0.0932 & 2.3 & .7584 \\
\hline 13.1 & 1.58 & 79 & 98 & 1.28 & 6.0 & 540 & \pm 13 & 326 & \pm 133 & -66 & 0.0529 & 5.9 & 0.6382 & 6.4 & 0.0874 & 2.6 & .4007 \\
\hline 14.1 & 2.27 & 66 & 89 & 1.39 & 5.3 & 563 & \pm 14 & 491 & \pm 204 & -15 & 0.0570 & 9.2 & 0.7177 & 9.6 & 0.0913 & 2.7 & .2776 \\
\hline 15.1 & 3.04 & 68 & 76 & 1.16 & 5.7 & 587 & \pm 15 & 12 & \pm 341 & -4829 & 0.0463 & 14.2 & 0.6088 & 14.4 & 0.0954 & 2.7 & .1849 \\
\hline
\end{tabular}




\begin{tabular}{|c|c|c|c|c|c|c|c|c|c|c|c|c|c|c|c|c|c|}
\hline \multirow{2}{*}{$\begin{array}{c}\begin{array}{r}\text { Grain } \\
\text { spot \# }\end{array} \\
\text { Totoró gab }\end{array}$} & \multirow{2}{*}{$\begin{array}{c}{ }^{\%} \mathrm{~Pb}_{c} \\
{ }^{206}\end{array}$} & \multirow[t]{2}{*}{$\begin{array}{c}U \\
{[\mathrm{ppm}]}\end{array}$} & \multirow[t]{2}{*}{$\begin{array}{c}\text { Th } \\
\text { [ppm] }\end{array}$} & \multirow[t]{2}{*}{${ }^{232} \mathrm{Th} /{ }^{238} \mathrm{U}$} & \multirow[t]{2}{*}{$\begin{array}{l}{ }^{206} \mathrm{~Pb}^{\star} \\
{[\mathrm{ppm}]}\end{array}$} & \multicolumn{2}{|c|}{$\begin{array}{c}{ }^{206} \mathrm{~Pb} /{ }^{238} \mathrm{U} \\
\text { age }\end{array}$} & \multicolumn{2}{|c|}{$\begin{array}{c}{ }^{207} \mathrm{~Pb} /{ }^{206} \mathrm{~Pb} \\
\text { age }\end{array}$} & \multirow[t]{2}{*}{$\%$ disc } & \multirow[t]{2}{*}{${ }^{207} \mathbf{P b}^{\star} /{ }^{206} \mathbf{P b}^{*}$} & \multirow[t]{2}{*}{ $\pm \%$} & \multirow[t]{2}{*}{${ }^{207} \mathrm{~Pb}^{\star 2} /{ }^{235} \mathrm{U}$} & \multirow[t]{2}{*}{ $\pm \%$} & \multirow[t]{2}{*}{${ }^{206} \mathrm{~Pb}{ }^{\star} /{ }^{238} \mathrm{U}$} & \multirow[t]{2}{*}{ $\pm \%$} & \multirow[t]{2}{*}{ err corr } \\
\hline & & & & & & & & & & & & & & & & & \\
\hline 1.1 & 0.70 & 160 & 225 & 1.45 & 13.0 & 576 & \pm 13 & 468 & \pm 77 & -23 & 0.0564 & 3.5 & 0.7271 & 4.2 & 0.0935 & 2.4 & .5626 \\
\hline 2.1 & 2.41 & 36 & 18 & 0.52 & 3.0 & 586 & \pm 17 & 501 & \pm 280 & -17 & 0.0572 & 12.7 & 0.7512 & 13.1 & 0.0952 & 3.1 & .2341 \\
\hline 3.1 & 2.52 & 68 & 43 & 0.64 & 5.6 & 577 & \pm 16 & 332 & \pm 305 & -74 & 0.0531 & 13.5 & 0.6858 & 13.8 & 0.0937 & 2.9 & .2087 \\
\hline 4.1 & 1.40 & 81 & 115 & 1.46 & 6.9 & 599 & \pm 15 & 581 & \pm 160 & -3 & 0.0594 & 7.4 & 0.7970 & 7.8 & 0.0974 & 2.6 & .3317 \\
\hline 5.1 & 1.66 & 94 & 131 & 1.44 & 7.7 & 575 & \pm 14 & 400 & \pm 159 & -44 & 0.0547 & 7.1 & 0.7036 & 7.5 & 0.0933 & 2.6 & .3385 \\
\hline 6.1 & 2.49 & 110 & 113 & 1.06 & 9.0 & 572 & \pm 15 & 444 & \pm 212 & -29 & 0.0558 & 9.5 & 0.7135 & 9.9 & 0.0927 & 2.7 & .2721 \\
\hline 7.1 & 4.98 & 125 & 193 & 1.61 & 10.1 & 554 & \pm 20 & 650 & \pm 598 & 15 & 0.0613 & 27.9 & 0.7587 & 28.1 & 0.0898 & 3.8 & .1335 \\
\hline 9.1 & 1.47 & 64 & 46 & 0.74 & 5.0 & 553 & \pm 12 & 735 & \pm 208 & 25 & 0.0638 & 9.8 & 0.7875 & 10.1 & 0.0895 & 2.2 & .2236 \\
\hline 10.1 & 1.30 & 68 & 67 & 1.01 & 5.6 & 579 & \pm 13 & 324 & \pm 157 & -78 & 0.0529 & 6.9 & 0.6849 & 7.3 & 0.0939 & 2.3 & .3117 \\
\hline 11.1 & 0.24 & 301 & 582 & 2.00 & 24.8 & 590 & \pm 9 & 561 & \pm 36 & -5 & 0.0588 & 1.6 & 0.7768 & 2.3 & 0.0958 & 1.6 & .7041 \\
\hline 13.1 & 0.46 & 404 & 749 & 1.92 & 34.2 & 604 & \pm 9 & 527 & \pm 45 & -14 & 0.0579 & 2.0 & 0.7840 & 2.6 & 0.0981 & 1.6 & .6122 \\
\hline 14.1 & 0.58 & 322 & 635 & 2.04 & 26.9 & 596 & \pm 9 & 519 & \pm 62 & -15 & 0.0577 & 2.8 & 0.7703 & 3.3 & 0.0968 & 1.6 & .4947 \\
\hline 15.1 & 0.98 & 142 & 215 & 1.56 & 11.9 & 594 & \pm 10 & 661 & \pm 91 & 10 & 0.0616 & 4.3 & 0.8196 & 4.6 & 0.0965 & 1.8 & .3886 \\
\hline 16.1 & 0.59 & 470 & 1039 & 2.28 & 38.7 & 587 & \pm 9 & 559 & \pm 48 & -5 & 0.0588 & 2.2 & 0.7725 & 2.7 & 0.0953 & 1.6 & .5884 \\
\hline 17.1 & 0.51 & 251 & 405 & 1.67 & 21.0 & 596 & \pm 9 & 690 & \pm 60 & 14 & 0.0625 & 2.8 & 0.8341 & 3.3 & 0.0968 & 1.7 & .5102 \\
\hline 18.1 & 0.88 & 251 & 443 & 1.83 & 21.6 & 610 & \pm 10 & 578 & \pm 74 & -6 & 0.0593 & 3.4 & 0.8117 & 3.8 & 0.0993 & 1.7 & .4482 \\
\hline \multicolumn{18}{|c|}{ Totoró diorite } \\
\hline 1.1 & 1.30 & 193 & 236 & 1.26 & 16.2 & 594 & \pm 16 & 379 & \pm 139 & -57 & 0.0542 & 6.2 & 0.7215 & 6.8 & 0.0965 & 2.8 & .4152 \\
\hline 2.1 & 1.64 & 252 & 212 & 0.87 & 21.4 & 598 & \pm 21 & 568 & \pm 129 & -5 & 0.0590 & 5.9 & 0.7911 & 6.9 & 0.0972 & 3.6 & .5217 \\
\hline 3.1 & 1.48 & 258 & 285 & 1.14 & 20.4 & 560 & \pm 15 & 607 & \pm 149 & 8 & 0.0601 & 6.9 & 0.7518 & 7.4 & 0.0907 & 2.7 & .3659 \\
\hline 4.1 & 1.16 & 141 & 148 & 1.08 & 11.5 & 578 & \pm 16 & 646 & \pm 128 & 10 & 0.0612 & 6.0 & 0.7918 & 6.7 & 0.0939 & 2.9 & .4406 \\
\hline 5.1 & 1.33 & 305 & 87 & 0.30 & 25.8 & 598 & \pm 15 & 566 & \pm 96 & -6 & 0.0590 & 4.4 & 0.7898 & 5.2 & 0.0972 & 2.7 & .5167 \\
\hline 6.1 & 0.72 & 296 & 479 & 1.67 & 25.2 & 603 & \pm 15 & 475 & \pm 76 & -27 & 0.0566 & 3.4 & 0.7650 & 4.3 & 0.0981 & 2.6 & .6070 \\
\hline 7.1 & 1.36 & 142 & 130 & 0.95 & 11.7 & 582 & \pm 20 & 726 & \pm 108 & 20 & 0.0635 & 5.1 & 0.8282 & 6.2 & 0.0945 & 3.5 & .5702 \\
\hline 8.1 & 0.19 & 447 & 790 & 1.83 & 39.2 & 626 & \pm 17 & 626 & \pm 50 & 0 & 0.0606 & 2.3 & 0.8522 & 3.7 & 0.1020 & 2.9 & .7766 \\
\hline 9.1 & 0.65 & 272 & 433 & 1.65 & 24.0 & 625 & \pm 16 & 631 & \pm 67 & 1 & 0.0608 & 3.1 & 0.8537 & 4.1 & 0.1019 & 2.6 & .6449 \\
\hline 10.1 & 0.46 & 499 & 62 & 0.13 & 42.9 & 613 & \pm 15 & 576 & \pm 40 & -6 & 0.0593 & 1.9 & 0.8144 & 3.2 & 0.0997 & 2.6 & .8102 \\
\hline 11.1 & 0.74 & 416 & 878 & 2.18 & 35.7 & 609 & \pm 15 & 473 & \pm 58 & -29 & 0.0565 & 2.6 & 0.7722 & 3.7 & 0.0991 & 2.6 & .7038 \\
\hline \multicolumn{18}{|c|}{ Totoró porphyritic granite } \\
\hline 1.1 & 3.47 & 140 & 124 & 0.92 & 11.8 & 584 & \pm 11 & 545 & \pm 318 & -7 & 0.0584 & 14.6 & 0.7634 & 14.7 & 0.0948 & 1.9 & .1323 \\
\hline
\end{tabular}




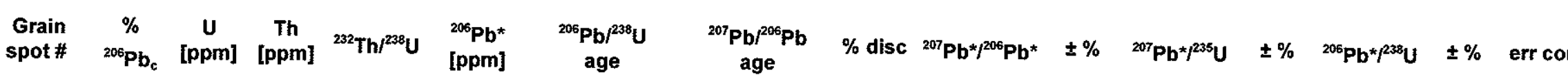

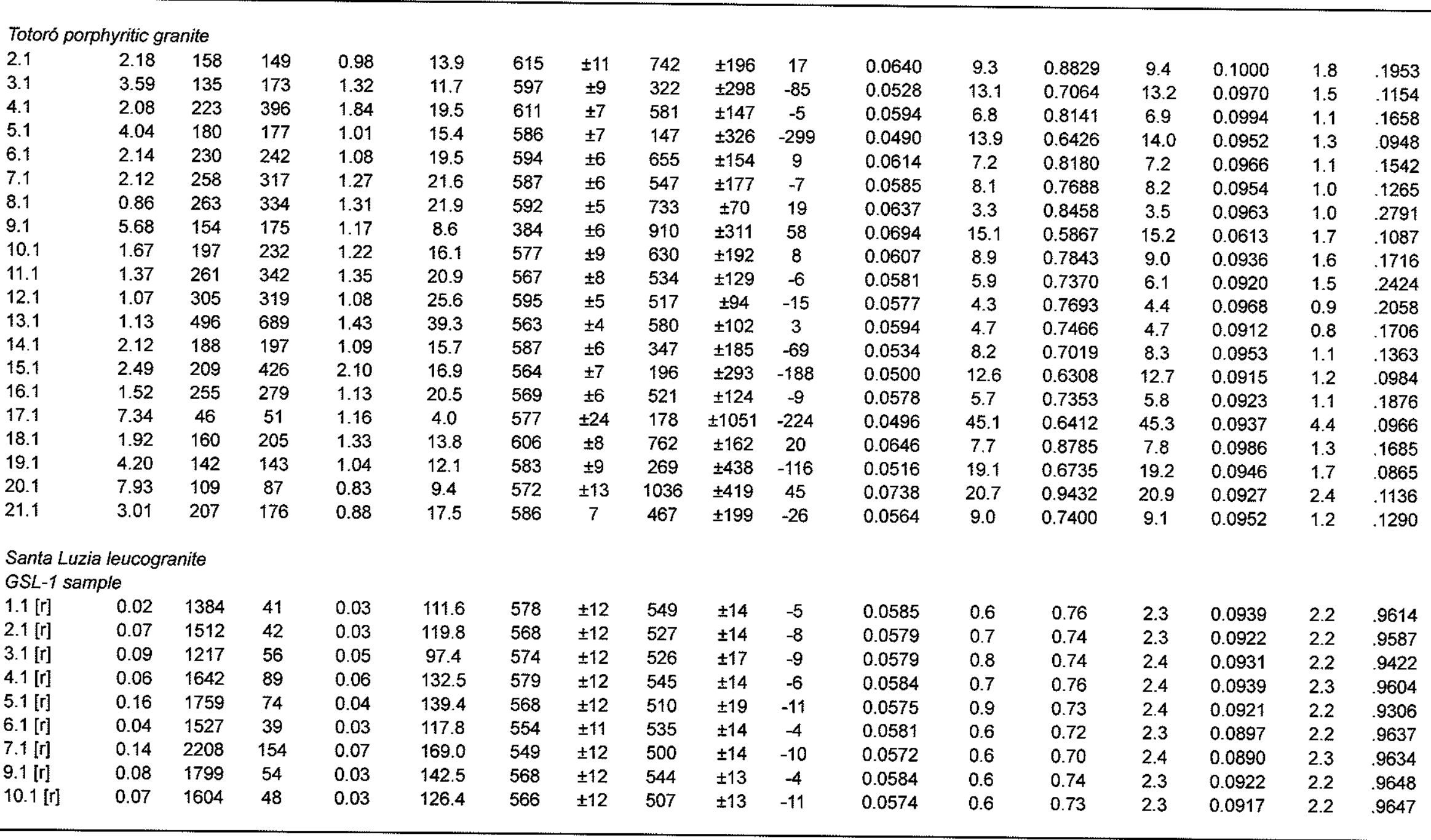


Tabela 1. cont.

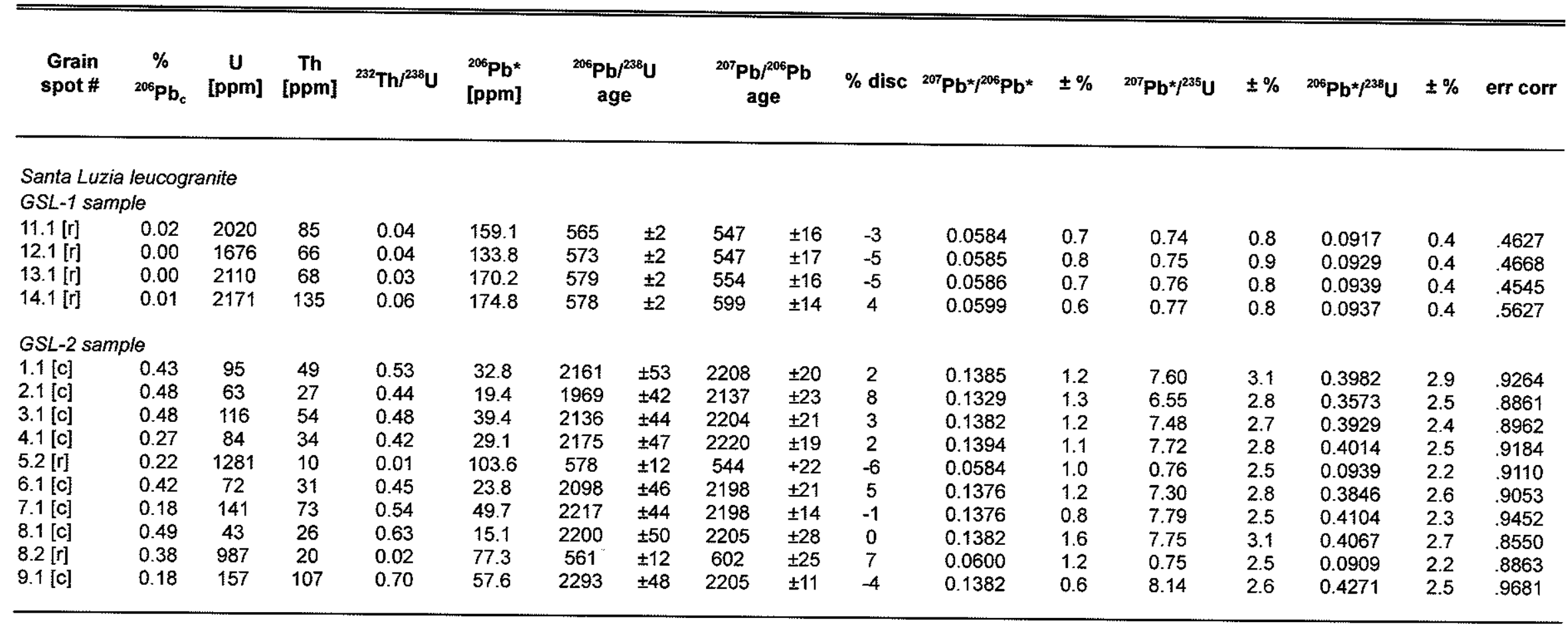


Table 2. AMS of the Santa Luzia anatexite.

\begin{tabular}{|c|c|c|c|c|c|c|c|c|c|c|c|c|c|}
\hline & & & & & K1 & & & K2 & & & K3 & & \\
\hline Site & $\mathrm{N}$ & $\mathrm{Km}$ & P & T & dec & inc & $\alpha 1$ & dec & inc & $\alpha 2$ & dec & inc & $\alpha 3$ \\
\hline SL01 & 7 & 22.400 & 1.212 & 0.372 & 344 & 58 & 27.6 & 202 & 26 & 27 & 104 & 17 & 31.3 \\
\hline SL02 & 11 & 9.580 & 1.137 & -0.187 & 18 & 24 & 13.3 & 271 & 34 & 23.9 & 135 & 46 & 23.7 \\
\hline SL03 & 10 & 2.870 & 1.234 & 0.134 & 345 & 36 & 82.5 & 158 & 55 & 82.5 & 253 & 3 & 15.8 \\
\hline SL04 & 8 & 3.310 & 1.259 & -0.199 & 180 & 16 & 11.2 & 301 & 61 & 21.5 & 83 & 23 & 21.5 \\
\hline SL05 & 7 & 0.278 & 1.102 & 0.148 & 183 & 22 & 27.4 & 281 & 18 & 30.7 & 46 & 60 & 18 \\
\hline SL06 & 7 & 8.470 & 1.386 & 0.304 & 199 & 27 & 16.6 & 298 & 16 & 17.3 & 55 & 58 & 17.9 \\
\hline SL07 & 7 & 11.200 & 1.212 & 0.069 & 193 & 18 & 58.8 & 310 & 54 & 58.3 & 92 & 30 & 29.2 \\
\hline SL08 & 7 & 4.780 & 1.222 & 0.207 & 188 & 7 & 21.2 & 284 & 41 & 32.3 & 91 & 48 & 32.8 \\
\hline SL09 & 6 & 0.909 & 1.121 & 0.281 & 338 & 12 & 33.2 & 80 & 45 & 54 & 237 & 42 & 50.9 \\
\hline SL10 & 9 & 17.300 & 1.282 & 0.136 & 225 & 40 & 21.7 & 135 & 0 & 19.5 & 45 & 50 & 15.6 \\
\hline SL11 & 8 & 1.400 & 1.179 & 0.350 & 359 & 1 & 35.4 & 268 & 72 & 33.3 & 89 & 18 & 18.7 \\
\hline SL12 & 9 & 5.100 & 1.261 & -0.019 & 214 & 41 & 28.5 & 33 & 49 & 30.5 & 124 & 26 & 26.5 \\
\hline SL13 & 8 & 4.620 & 1.279 & 0.075 & 213 & 14 & 15.1 & 317 & 45 & 16.5 & 110 & 42 & 16.5 \\
\hline SL14 & 8 & 10.600 & 1.122 & -0.001 & 195 & 10 & 4.8 & 293 & 37 & 12.4 & 92 & 51 & 12.5 \\
\hline SL15 & 7 & 1.280 & 1.182 & 0.026 & 8 & 46 & 35.4 & 227 & 37 & 34.7 & 120 & 20 & 22.5 \\
\hline SL16 & 7 & 0.390 & 1.061 & -0.135 & 24 & 5 & 11.6 & 219 & 85 & 21.3 & 114 & 1 & 22 \\
\hline SL17 & 6 & 21.500 & 1.180 & 0.072 & 40 & 1 & 7.9 & 310 & 18 & 16 & 131 & 72 & 16 \\
\hline SL18 & 12 & 6.720 & 1.169 & 0.121 & 15 & 5 & 9.9 & 276 & 57 & 14.4 & 109 & 32 & 14.4 \\
\hline SL19 & 8 & 0.176 & 1.021 & -0.175 & 5 & 23 & 22.4 & 210 & 65 & 28.8 & 99 & 9 & 25.6 \\
\hline SL20 & 7 & 0.141 & 1.095 & 0.147 & 331 & 8 & 44.2 & 236 & 32 & 73.6 & 73 & 57 & 74.1 \\
\hline SL21 & 8 & 4.130 & 1.308 & 0.161 & 218 & 11 & 29.4 & 356 & 75 & 49.9 & 126 & 10 & 50.5 \\
\hline SL22 & 7 & 12.100 & 1.415 & -0.238 & 212 & 19 & 20.7 & 68 & 67 & 24.1 & 307 & 12 & 17.5 \\
\hline SL23 & 8 & 8.140 & 1.213 & -0.053 & 256 & 52 & 56 & 349 & 2 & 55.8 & 80 & 38 & 36.7 \\
\hline SL24 & 7 & 7.070 & 1.270 & -0.068 & 199 & 11 & 15.1 & 297 & 36 & 15.6 & 95 & 52 & 16.1 \\
\hline SL25 & 7 & 3.280 & 1.191 & 0.178 & 181 & 19 & 30.2 & 290 & 44 & 53.9 & 74 & 40 & 53.7 \\
\hline SL26 & 7 & 4.500 & 1.367 & -0.228 & 185 & 34 & 15.8 & 18 & 56 & 36.7 & 279 & 6 & 36.7 \\
\hline SL27 & 8 & 11.600 & 1.333 & -0.052 & 210 & 28 & 22.4 & 119 & 2 & 23.2 & 26 & 62 & 22.2 \\
\hline SL28 & 7 & 5.650 & 1.267 & -0.008 & 178 & 14 & 17.9 & 284 & 47 & 23.5 & 77 & 39 & 24.2 \\
\hline SL29 & 7 & 2.390 & 1.173 & 0.025 & 5 & 23 & 32.2 & 201 & 66 & 32.8 & 98 & 6 & 17.8 \\
\hline SL30 & 8 & 14.500 & 1.315 & 0.285 & 28 & 9 & 53.4 & 291 & 38 & 53.4 & 129 & 51 & 18.4 \\
\hline SL31 & 8 & 6.120 & 1.270 & -0.258 & 12 & 15 & 14.5 & 205 & 75 & 14.3 & 103 & 3 & 10 \\
\hline SL32 & 6 & 17.400 & 1.259 & 0.118 & 238 & 9 & 24.8 & 336 & 41 & 19.1 & 137 & 48 & 20.4 \\
\hline SL33 & 7 & 0.217 & 1.019 & -0.228 & 38 & 23 & 17.1 & 260 & 60 & 18.8 & 135 & 18 & 17 \\
\hline SL34 & 6 & 10.000 & 1.297 & 0.031 & 203 & 4 & 22.3 & 325 & 82 & 28 & 112 & 6 & 28.6 \\
\hline SL35 & 7 & 7.680 & 1.120 & -0.098 & 36 & 11 & 10 & 178 & 76 & 12.3 & 305 & 8 & 10.3 \\
\hline SL36 & 6 & 7.240 & 1.179 & 0.187 & 210 & 6 & 17.7 & 318 & 72 & 16 & 118 & 17 & 9.1 \\
\hline SL37 & 7 & 1.240 & 1.260 & -0.199 & 32 & 27 & 24.6 & 174 & 57 & 26.1 & 293 & 16 & 15.9 \\
\hline SL38 & 7 & 1.200 & 1.094 & -0.015 & 31 & 12 & 5.9 & 273 & 65 & 8.1 & 126 & 21 & 8.1 \\
\hline SL39 & 5 & 2.290 & 1.290 & -0.297 & 196 & 24 & 39.6 & 34 & 65 & 39.5 & 289 & 7 & 15.3 \\
\hline SL40 & 5 & 14.900 & 1.358 & 0.021 & 198 & 20 & 19.8 & 289 & 4 & 20.7 & 28 & 69 & 17 \\
\hline SL41 & 5 & 9.660 & 1.203 & 0.264 & 4 & 2 & 16.4 & 98 & 54 & 18.9 & 273 & 36 & 15.1 \\
\hline SL42 & 6 & 4.530 & 1.204 & 0.018 & 196 & 10 & 83.3 & 291 & 25 & 83.4 & 85 & 63 & 34.3 \\
\hline
\end{tabular}

$\mathrm{N}$, number of specimens; $\mathrm{Km}$, mean-site susceptibility $\left(10^{-3} \mathrm{SI}\right) ; \mathrm{P}$, anisotropy degree; $\mathrm{T}$, shape parameter. $\mathrm{K} 1, \mathrm{~K} 2$ and $\mathrm{K} 3$ are the orientations (declination, inclination) of the AMS principal directions, and $\alpha 1, \alpha 2$ and $\alpha 3$ are the angular dispersion represented by the maximum semi-angle (degrees) of the confidence cone around the mean direction. 


\section{CAPÍTULO 4}

Neste capiítulo são apresentados os resultados geocronológicos U-Pb SHRIMP em zircões de leucogranitos tardi-brasilianos da Faixa Seridó e Re-Os para molibdenitas dos depósitos de Brejuí, Bodó e Bonfim (RN). Também são apresentados dados isocrônicos Sm-Nd e $\mathrm{Pb}-\mathrm{Pb}$ (rocha total e lixiviação gradual) dos minerais calciosilicatados que constituem as paragêneses de alta e baixa temperatura geradas durante a skarnitização, visando sua comparação com as idades Re-Os em molibdenitas. Todo esse conjunto analítico foi obtido no âmbito do projeto Fapesp 07/58974-0 "GEOCRONOLOGIA DE MINERALIZAÇÕES DE W-MOE SUA ASSOCIAÇÃO TEMPORAL COM O MAGMATISMO NEOPROTEROZOICO NA FAIXA SERIDÓ (PROVÍNCIA BORBOREMA)", executado entre Agosto/2008 e Julho/2011. 


\section{INTRODUÇÃO - resumo do projeto}

Mais que 300 ocorrências de skarns mineralizados em scheelita-sulfetos são cartografadas na Faixa Seridó, segundo o Mapa Geológico do Estado do Rio Grande do Norte. Explorada desde os anos 40, a scheelita foi intensamente lavrada até 1985 , tendo produzido $c$. 70 mil toneladas de concentrado contendo em média $70 \% \mathrm{WO}_{3}$, obtido a partir de um minério com teor médio de $0.7-1 \% \mathrm{WO}_{3}$. Já no início da década de 80 , a atividade mineradora declinou significativamente em conseqüência da queda no preço do $W$ no mercado mundial. $A$ queda decorreu da entrada da China no mercado internacional, produzindo grandes quantidades de concentrado de minério. Atualmente, em função do cenário internacional propício à exploração da scheelita, algumas minas vêm retomando sua atividade de lavra. Dentre essas destacam-se as minas Brejuí, Barra Verde, Boca de Lage, Bodó e Bonfim, bem como garimpos diversos na região de Currais Novos (RN).

A maioria das ocorrências de scheelita-sulfetos ocorre hospedada em rochas hidrotermais calciosilicatadas (skarns) que desenvolvem-se preferencialmente no contato entre paragnaisses e lentes de mármore da Formação Jucurutu e, subordinadamente, como bolsões dentro destes litotipos. Modelos de evolução singenética (sedimentar ou vulcanosedimentar) e epigenética (metassomatismo hidrotermal) foram aventados para explicar a gênese da scheelita e dos sulfetos associados. A hipótese epigenética foi confirmada com o estudo petrogenético realizado na Mina Brejuí, a partir da descrição detalhada de paragêneses metassomáticas constituídas por assembléias minerais específicas. A primeira assembléia metassomática caracteriza os skarns primários formados sob condições P-T de c. $550^{\circ}-450^{\circ} \mathrm{C}$ (fácies anfibolito) e c. 3 - 2 Kbar (baixa pressão). Superposta a essa assembléia um segundo evento hidrotermal teria modificado as associações mineralógicas primárias para novas paragêneses estáveis a condições P-T mais brandas (fácies epidoto-prehnita e a zeólitas) originando skarns porosos, secundários.

A scheelita economicamente explorada e os sulfetos (molibdenita, pirita, calcopirita, bornita e magnetita) estão preferencialmente associados ao segundo episódio metassomático. Nesse contexto ela ocorre como cristais grossos, de formação tardia, concentrados em bandas estruturalmente localizadas ao longo de charneiras de dobras e zonas de cisalhamento regionais desenvolvidos durante a orogênese Brasiliana (casos das minas Brejuí e Bodó). A assembléia scheelita-molibdenita também pode ocorrer em veios feldspáticos, sob condições de fácies anfibolito, particularmente estudada na Mina Bonfim. Além dessa forma de ocorrência, grãos finos de scheelita-molibdenita (formação precoce) ocorrem ainda disseminados concordantemente ao bandamento observado nos skarns primários.

A scheelita ocorre naturalmente variando entre as cores branca ou amarela, muito embora uma variedade escura também seja encontrada resultante da presença de finas 
palhetas de molibdenita orientadas segundo o plano de clivagem da scheelita. Essa particularidade textural implica em teores mais elevados de $\mathrm{MoO}_{3}$, os quais podem chegar a $1 \%$. No entanto, a composição quimica média da scheelita é de $78,5 \% \mathrm{WO}_{3}, 19,3 \% \mathrm{CaO}, 0,2 \%$ $\mathrm{MgO}$ e $0,5 \% \mathrm{MoO}_{3}$. Dos sulfetos associados à scheelita, molibdenita, pirita, calcopirita e bornita são os mais importantes. Magnetita, bismuto nativo e pirrotita também podem estar presentes. No contexto geológico regional é importante mencionar a relação espacial próxima entre as ocorrências de scheelita-sulfetos e corpos granitóides. Alguns autores acreditam que o fluxo térmico proveniente das intrusões granítico-dioríticas associado à percolação de fluidos metamórficos ao longo das zonas de cisalhamento regionais seriam principais responsáveis pelas transformações metamórficas/hidrotermais skarníticas.

Foram dois os objetivos deste projeto. O primeiro, de caráter essencialmente científico consistiu em estabelecer a idade absoluta da atividade metamórfica/hidrotermal que deu origem às mineralizações de scheelita $\left(\mathrm{CaWO}_{4}\right)$-molibdenita $\left(\mathrm{MoS}_{2}\right)$ hospedadas em skarns da Formação Jucurutu e observar sua relação temporal com o magmatismo brasiliano. Para atingir esse objetivo buscou-se a datação direta dos próprios minerais-minérios de W-Mo, dos minerais metamórficos que caracterizam as paragêneses skarníticas e dos corpos granitóides que ocorrem espacialmente próximos às ocorrências minerais. Os alvos foram as ocorrências de Brejuí, Bodó e Bonfim, bem caracterizadas quanto ao reconhecimento de suas paragêneses metamórficas e as relações destas com os minerais-minérios. Os granitóides datados foram de Acari, Totoró, Picuí e Cerro Corá que ocorrem em proximidade regional com as ocorrências citadas (Fig. 1).

O segundo objetivo teve caráter metodológico. Inúmeros estudos têm sido publicados nos últimos anos abordando procedimentos analíticos desenvolvidos para aplicação em problemas semelhantes ao aqui proposto. O sistema isotópico ${ }^{187} \mathrm{Re} /{ }^{187}$ Os constitui o geocronômetro mais confiável para datação de molibdenita uma vez que este mineral contém altos teores de $\operatorname{Re} e$, a priori, nenhum Os comum ou inicial. Em paralelo com a obtenção de idades Re-Os, aplicou-se os métodos $\mathrm{Pb} / \mathrm{Pb}$ por lixiviação ( $\mathrm{Pb}$ Stepwise Leaching - PbSL) e $\mathrm{Sm}-\mathrm{Nd}$ nas fases minerais paragenéticas para comparar o comportamento desses três sistemas isotópicos (Re-Os, PbSL, Sm-Nd) em uma paragênese mineral típica de um sistema hidrotermal crustal. 


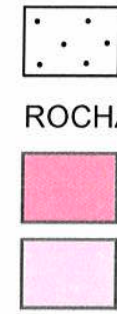

Sedimentos arenosos

Biotita (muscovita) granito, pegmatito

Granito porfirítico, leucogranito, quartzo-monzonito diorito $(\cdot)$ (localmente gabro)

GRUPO SERIDÓ

Metapelito, lentes de quartzito (Fm Seridó)

Mármore, micaxisto, paragnaisse

(Fm Jucurutu)

Quartzito, conglomerado (Fm Equador)

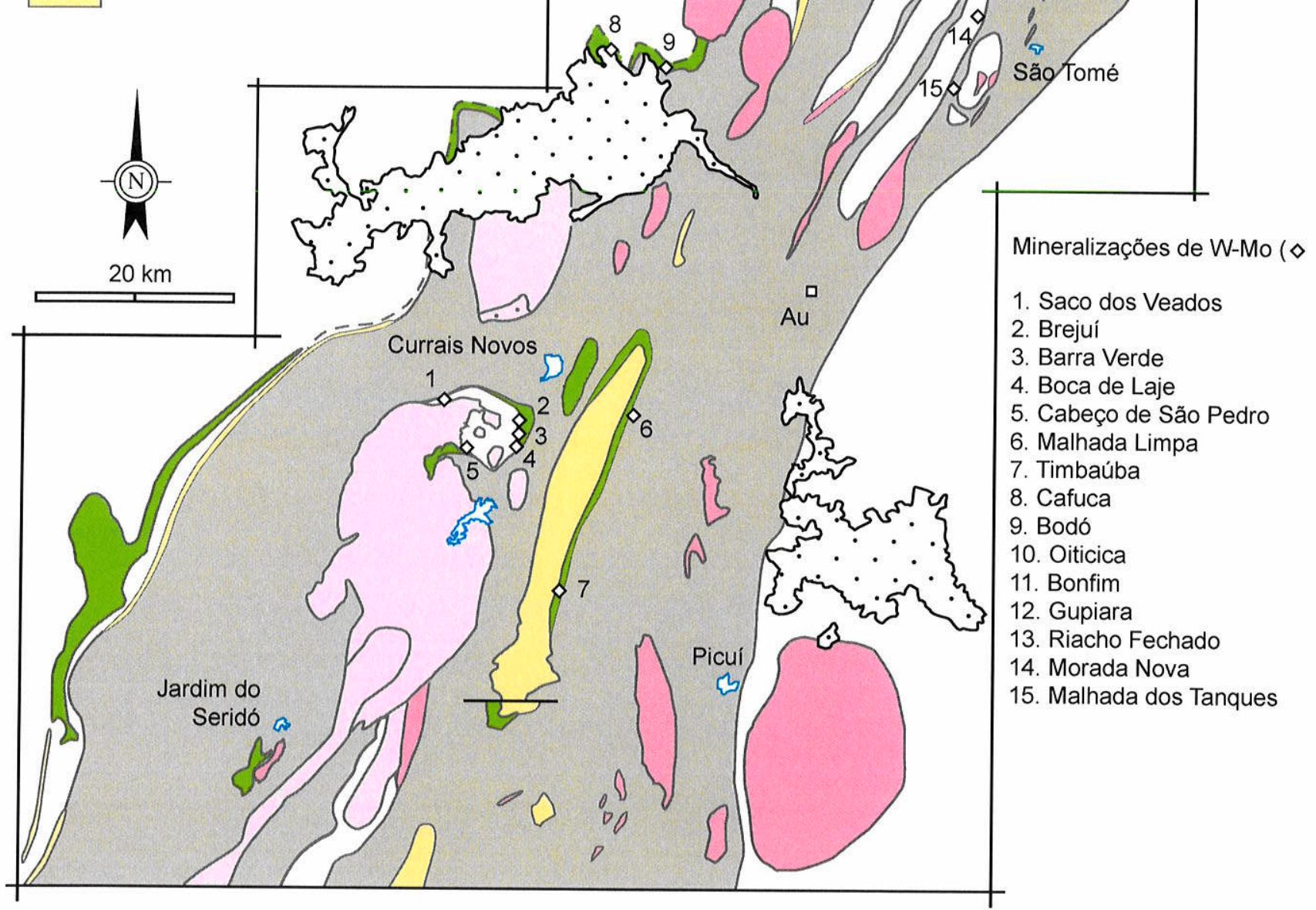

Figura 1. Mapa geológico simplificado da região central da Faixa Seridó destacando as unidades litoestratigráficas neoproterozoicas (rochas metasedimentares e granitóides brasilianos) e os principais depósitos de W-Mo na faixa. 


\section{INFORMAÇÕES SOBRE AS METODOLOGIAS ADOTADAS NO PROJETO}

\subsection{Separação mecânica de minerais}

De forma geral, as amostras das minas Brejui, Bodó e Bonfim consistem em skarns grossos que apresentam uma assembléia mineral primária relativamente simples constituída de hornblenda, diopsídio, grossulária/almandina, plagioclásio e quartzo. Essa paragênese primária é alterada por fluidos hidrotermais formando uma assembléia mineral secundária complexa cujos principais representantes são vesuvianita, epidoto/clinozoisita, carbonato, feldspatos, zeólitas e quartzo. Acrescenta-se ainda scheelita $\left(\mathrm{CaWO}_{4}\right)$, fluorita $\left(\mathrm{CaF}_{2}\right)$ e sulfetos de $\mathrm{Fe}-\mathrm{Cu}-$ Mo e, particularmente no caso da mina Bonfim, também sulfetos de Bi e localmente Au. Essa superposição de eventos é um fator agravante quando a questão é a individualização das fases minerais, muitas das quais com inclusões/substituição de/por outras fases minerais dificultando a obtenção de concentrados puros.

A rotina adotada envolveu britagem, peneiramento, separação magnética, eluição com liquidos densos e catação em lupa binocular (ver Tabela 1), cuja eficiência foi validada por análises dos espécimes minerais separados por difratometria de raios- $X$. Todas as frações de minerais concentradas para análise $\mathrm{Sm} / \mathrm{Nd}$ e $\mathrm{Pb} / \mathrm{Pb}$ foram consideradas puras, sem que a presença de contaminantes ultrapassasse $2 \%$. Foram considerados contaminantes fases minerais que puderam ser detectadas por difratometria de raios- $X$ e identificadas por picos característicos em $2 \theta$ (ver exemplos no Anexo 01). Incluídas nessa condição está a presença incipiente de fluorita e mica na fração scheelita das minas Brejuí e Bonfim, respectivamente, e mica na fração clinozoisita da mina Bonfim, todos não detectáveis por observação visual em microscópio estereoscópico. Por esse motivo (e também por informações de trabalhos petrográficos disponiveis na literatura) acreditamos que tais contaminantes estejam presentes como fases de substituição provavelmente em equilíbrio isotópico com os minerais hospedeiros.

A heterogeniedade textural e mineralógica dos skarns impossibilitou a obtenção de amostras que fossem representativas do sistema 'rocha-total' normalmente considerado quando trabalhamse com métodos isocrônicos. Sendo assim, as isócronas $\mathrm{Sm} / \mathrm{Nd}$ e $\mathrm{Pb} / \mathrm{Pb}$ foram construídas apenas com os pontos analíticos dos minerais calciossilicatados.

\subsection{Rotinas analíticas Sm-Nd e PbSL no CPGeo}

Os procedimentos para análise $\mathrm{Sm}-\mathrm{Nd}$ foram aqueles rotineiramente utilizados no CPGeo e estão sintetizados na Tabela 2. Apenas para scheelita foi aplicada uma rotina 
diferenciada, internamente modificada de Liu et al. (2007), que inclui etapas de dissolução em bomba de alta pressão Parr® e em béquer Savillex®.

A rotina utilizada para obtenção de dados $\mathrm{Pb} / \mathrm{Pb}$ por lixiviação incluiu adaptações a partir de Frei e Kamber (1995) e Frei et al. (1998), que sugere a obtenção de 4-5 alíquotas para cada fase mineral a partir da dissolução seletiva por etapas onde são variados tempo de abertura, tipo ( $\mathrm{HF}, \mathrm{HNO}_{3}, \mathrm{HCl}, \mathrm{HBr}$ ) e concentração de ácidos. Esse procedimento propicia a obtenção de uma ampla variação das razões isotópicas de $\mathrm{Pb}$, implicando em maior possibilidade de construção de isócronas precisas. Detalhes são listados na Tabela 3.

Tabela 1. Procedimentos para separação mecânica de minerais calciosilicatados.

\begin{tabular}{|c|c|c|c|c|}
\hline Mineral & $\begin{array}{c}\text { Separação magnética } \\
1^{\mathrm{a}} \text { etapa }\end{array}$ & $\begin{array}{c}\text { Separação magnética } \\
2^{\mathrm{a}} \text { etapa }\end{array}$ & Purificação & $\begin{array}{c}\text { Etapa adicional de } \\
\text { purificação }\end{array}$ \\
\hline - Anfibólio & Magnética a $0.5 \mathrm{~A}-10^{\circ}$ & Magnética a $0.6 \mathrm{~A}-20^{\circ}$ & Catação & \\
\hline Calcita & Não-magnética a $0.5 \mathrm{~A}-10^{\circ}$ & Não-magnética a $1.2 \mathrm{~A}-10^{\circ}$ & Líq. Denso* & Catação \\
\hline Clz-epidoto & Não-magnética a $1.0 \mathrm{~A}-10^{\circ}$ & & Catação & ( \pm Liq. Denso) \\
\hline - Granada & Magnética a $0.3 \mathrm{~A}-10^{\circ}$ & & Catação & \\
\hline · Piroxênio & Magnética a $0.5 \mathrm{~A}-10^{\circ}$ & & Catação & Ataque ácido \\
\hline - Scheelita & Não magnética a $0.5 \mathrm{~A}-10^{\circ}$ & Não magnética a $0.7 \mathrm{~A}-10^{\circ}$ & Líq. Denso & $\begin{array}{l}\text { Separação } \\
\text { magnética** }+ \\
\text { catação }\end{array}$ \\
\hline - Vesuvianita & Magnética a $0.5 \mathrm{~A}, 10^{\circ}$ & Magnética a $0.3 \mathrm{~A}-10^{\circ}$ & Catação & - \\
\hline
\end{tabular}

Tabela 2. Procedimentos para dissolução química dos minerais calciosilicatados.

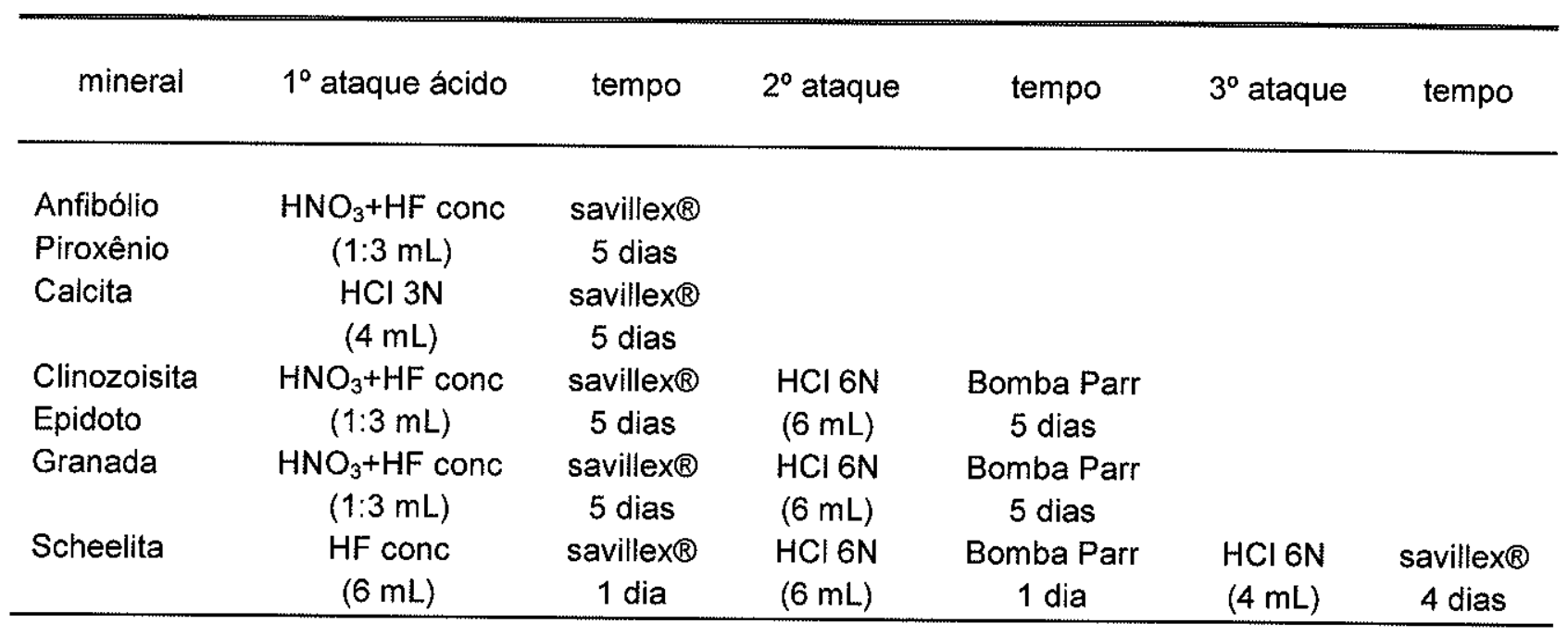


Tabela 3. Detalhes do procedimento para lixiviação de minerais calciosilicatados, scheelita e molibdenita.

\begin{tabular}{|c|c|c|c|}
\hline etapas de lixiviação & ataques ácidos & condições de repouso & tempo $(\mathrm{h})$ \\
\hline \multicolumn{4}{|c|}{ Para minerais calciosilicatados } \\
\hline 1 & $\mathrm{HBr} 1.5 \mathrm{~N}+\mathrm{HCl} 2 \mathrm{~N}(12: 1 \mathrm{~mL})$ & ultrasom & 5 \\
\hline 2 & $\mathrm{HBr} 8.8 \mathrm{~N}$ & ultrasom+chapa & 16 \\
\hline 3 (aplicada só p/ granada) & $\mathrm{HBr} 8.8 \mathrm{~N}$ & chapa & 16 \\
\hline 4 & $\mathrm{HNO}_{3} 14 \mathrm{~N}$ & chapa & 12 \\
\hline 5 & HF $45 \%$ & chapa & 48 \\
\hline \multicolumn{4}{|l|}{ Para scheelita } \\
\hline 1 & $\mathrm{HBr} 1.5 \mathrm{~N}+\mathrm{HCl} 2 \mathrm{~N}(12: 1 \mathrm{~mL})$ & ultrasom & $15 \mathrm{~min}$ \\
\hline 2 & $\mathrm{HCl} 2 \mathrm{~N}$ & chapa & 2 \\
\hline 3 & $\mathrm{HCl} 7 \mathrm{~N}$ & chapa & 24 \\
\hline 4 & $\mathrm{HNO}_{3} 14 \mathrm{~N}$ & chapa & 48 \\
\hline 5 & resíduo & - & - \\
\hline \multicolumn{4}{|l|}{ Para molibdenita } \\
\hline 1 & $\mathrm{HBr} 1.5 \mathrm{~N}+\mathrm{HCl} 2 \mathrm{~N}(12: 1 \mathrm{~mL})$ & ultrasom & $5 \mathrm{~min}$ \\
\hline 2 & $\mathrm{HBr} 1 \mathrm{~N}$ & ultrasom+chapa & $30 \mathrm{~min}$ \\
\hline 3 & $\mathrm{HNO}_{3} 7 \mathrm{~N}$ & chapa & 12 \\
\hline 4 & residuo & - & - \\
\hline
\end{tabular}

\subsection{Rotina analítica Re-Os}

Três amostras de molibdenitas coletadas nas minas Brejuí, Bodó e Bonfim foram analisadas para determinações Re-Os na Colorado State University, aos cuidados da Dra Holly Stein. Todos os procedimentos analíticos, inclusive a separação de concentrados de molibdenita a partir de amostras de mão, foram realizados de forma criteriosa pelo laboratório nos EUA. Os resultados analíticos estão apresentados no Anexo 01 . Aproximadamente $20 \mathrm{mg}$ de cada concentrado purificado foram individualmente submetidos a ataque ácido com água régia, com adição de uma solução de spike duplo de Os. O uso do spike foi útil informar alguma possivel fração de Os comum nas amostras.

\subsection{Rotina U-Pb SHRIMP em zircão}

Foram selecionados os plútons de Acari e Totoró representados por granitos porfiríticos em estreita associação com dioritos-gabro, aflorando adjacentes às minas Brejuí e Bodó, e ainda os leucogranitos de Picuí, localizado na borda leste da faixa central, no contato com o 
embasamento paleoproterozoico São José do Campestre, e o de Cerro-Corá a NE do platô de Santana também no limite metasedimentos-embasamento. Um pequeno corpo ígneo de composição sienogranítica que aflora em galeria da mina Bonfim também foi considerado. No entanto, a datação foi inviabilizada pelo aspecto metamitizado dos zircões mostrados na observação em lupa e nas imagens de catodoluminescência.

O procedimento prévio à análise U-Pb iniciou com a separação mecânica do zircão a partir da rocha total ao longo de em várias etapas que incluem britagem, peneiramento, separação magnética e por densidade, e purificação em lupa binocular. A primeira etapa consistiu em preparar a amostra em um britador de mandíbulas utilizando-se uma quantidade aproximada de $5 \mathrm{~kg}$, e reduzindo-se a amostra até aproximadamente $1 \mathrm{~cm}$. Uma fração mais fina foi obtida em moinho de disco para que o material possa ser, a seguir, peneirado em um conjunto composto por malhas de 60,100 e 250 mesh. A fração de 100 e 250 mesh foi depositada em uma mesa vibratória tipo Wiffley com objetivo de separar, por fluxo aquoso, os minerais leves (quartzo, feldspatos, micas) dos minerais pesados (anfibólios, piroxênios, granada, monazita, rutilo, zircão, apatita, magnetita, ilmentita, etc.). A fração de minerais pesados foi submetida à separação magnética inicial com um imã de mão e, em seguida, em um equipamento tipo Frantz ${ }^{\circledR}$ com controle na regulagem da inclinação da calha e amperagem da corrente. A intenção foi obter um concentrado mais puro possível de zircão. A etapa final de purificação foi feita utilizando-se líquidos densos, bromofórmio -densidade $2,82 \mathrm{~g} / \mathrm{cm}^{3}$ e iodeto de metileno - densidade $3,32 \mathrm{~g} / \mathrm{cm}^{3}$.

Cerca de 100 grãos de zircão foram selecionados para montagem em discos de resina epoxy $(2,5 \mathrm{~cm}$ diâmetro e $0,5 \mathrm{~cm}$ de altura) que foram, em seguida, polidos até aproximadamente a metade dos grãos para expor sua estrutura interna. As imagens de catodoluminescência desses grãos foram tomadas em microscópio eletrônico de varredura com detector de catodoluminescência. As análises isotópicas foram realizadas em uma microssonda iônica SHRIMP II, no Beijing Geochronological Center (China). Os detalhes analíticos são os mesmos reportados nos capítulos anteriores. 


\section{RESULTADOS}

\subsection{Isócronas Sm-Nd para as paragêneses de alta e baixa temperatura nas minas Brejuí e Bodó}

Quando consideradas em conjunto as minas Brejuí e Bodó mostram paragêneses minerais semelhantes, distinguidas por uma série de alta temperatura e uma série de baixa temperatura. Os skarns primários (alta $\mathrm{T}: 600^{\circ}-550^{\circ} \mathrm{C}$ ) apresentam uma coluna metassomática definida pela presença de anfibólio (hornblenda), piroxênio (diopsídio-hedenbergita) e granada (grossulária-andradita), desenvolvida a partir do paragnaisse em direção ao mármore. A atuação do segundo evento metassomático deu-se sobre essa paragênese primária, promovendo a alteração tardia dos skarns com associação poliminerálica (baixa T) caracterizada pelas paragêneses escapolita-vesuvianita $\left(450^{\circ}-380^{\circ} \mathrm{C}\right)$, epidoto-prehnita $\left(380^{\circ}\right.$ $270^{\circ} \mathrm{C}$ ) e zeólitas $\left(300^{\circ}-200^{\circ} \mathrm{C}\right)$. Obedecendo as relações genéticas entre essas fases, a definição de idades isocrônicas foi estabelecida usando-se as fases paragenéticas separadamente. Vários gráficos isocrônicos são apresentados abaixo ilustrando a distribuição das composições isotópicas Sm-Nd dessas fases minerais. A mineralização de scheelita (e sulfetos) concentra-se preferencialmente nos skarns secundários, motivo pelo qual este mineral foi incluído na paragênese de baixa $T$.

Notadamente observa-se que em nenhum dos casos foi possível verificar o ajuste dos pontos analíticos em definir isócronas com boa precisão. Todos os resultados são comuns quanto a: (i) idades absolutas com grande variação entre si, (ii) erros muito altos associados às idades absolutas e (iii) MSWD anomalamente elevados. Dos dados Sm/Nd disponíveis nota-se que grande parte dos minerais calciossilicatados apresentam concentrações muito baixas de $\mathrm{Sm}$ e Nd quando comparadas com outros skarns a scheelita do mundo (p. ex., Kent et al., 1995; Kempe et al., 2001; Brugger et al., 2002; Liu et al., 2007). Esse comportamento pode ser, em parte, um reflexo das concentrações já muito baixa de elementos terras raras obtidas para os mármores hospedeiros, associadas à composições também empobrecidas dos fluidos mineralizantes. É possível que essa seja a explicação para a não obtenção de dados $\mathrm{Sm} / \mathrm{Nd}$ para anfibólio e calcita de Bodó, por exemplo; ambos foram submetidos a dois ataques ácidos e em nenhuma das tentativas houve geração de sinal analítico estável e forte o suficiente para ser medido com precisão por espectrometria de massa.

Uma isócrona (errócrona) com três pontos foi obtida para a paragênese de alta temperatura de Brejuí, fornecendo um resultado com idade em $809 \pm 2800 \mathrm{Ma}$ (MSWD = 606; Fig. 2A). Diopsídio está deslocado do melhor ajuste calculado para esses pontos, de forma que, em um segundo exercício, foram considerados apenas granada e anfibólio. $O$ alinhamento desses dois pontos forneceu idade de $592 \pm 24 \mathrm{Ma}$ (Fig. 2B). É importante observar que 
qualquer interpretação de idades isocrônicas definidas pelo ajuste de dois pontos é considerada estatisticamente pouco representativa, e deve ser tomada como uma aproximação, válida somente após confirmação com outro método isotópico. Para melhorar a estatística para o cálculo da idade incluímos um ponto analítico (B1h) referente à uma 'rochatotal' para esses minerais. A idade calculada se manteve semelhante a anterior, de $596 \pm 24$ Ma (MSWD = 2.7) (Fig. $2 \mathrm{C}$ ), mas ressaltamos a dificuldade (neste caso) em validar uma amostra de rocha total como representativa visto que os minerais não se distribuem homogeneamente, sua composição podendo retratar contribuição maior de uma ou outra fase em relação às demais.

A idade para a paragênese de baixa temperatura de Brejuí foi tentativamente determinada pelos dados das fases minerais vesuvianita, epidoto, calcita e scheelita. $O$ melhor ajuste entre essas quatro fases minerais produziu uma errócrona com idade de $507 \pm 400 \mathrm{Ma}$ (MSWD = 18; Fig. 3A). O erro excessivamente elevado é explicado pelo estreito espalhamento das razões ${ }^{147} \mathrm{Sm} /{ }^{144} \mathrm{Nd}$ dos pontos analíticos, entre c. 0,16 (do epidoto) e 0,06 (da scheelita). Se considerada isoladamente, a idade absoluta aponta o caráter tardio (como esperado) dessa paragênese em relação àquela de alta temperatura. Um exercício adicional foi feito também incluindo na regressão dados analíticos $\mathrm{Sm}-\mathrm{Nd}$ de outras amostras de vesuvianita, scheelita e epidoto obtidos por I. Trindade, resultando em uma errócrona com MSWD = 82; mesmo com a exclusão dos pontos mais dispersos ainda manteve-se uma errócrona com idade de $482 \pm 140$ $\mathrm{Ma}$ (MSWD = 16; Fig. 3B).

Para Bodó, a determinação da idade $\mathrm{Sm}-\mathrm{Nd}$ a partir dos minerais de alta temperatura foi fortemente prejudicada uma vez que anfibólio e piroxênio não apresentaram teores suficientes o bastante para serem detectados, mesmo por TIMS. Face a isso, a composição isotópica da granada não pode ser utilizada em qualquer regressão. Da mesma forma, a determinação de uma idade Sm-Nd para a paragênese de baixa temperatura também ficou prejudicada pela exclusão da análise de calcita, a qual (como anfibólio e piroxênio) também não gerou sinal passivel de ser medido. A dispersão das composições isotópicas de epidoto, vesuvianita e scheelita não puderam ser ajustadas ao longo de uma regressão, impossibilitando a indicação de qualquer idade para essa paragênese.

Em síntese, a aplicação da geocronologia $\mathrm{Sm}-\mathrm{Nd}$ aos minerais calciossilicatados das mineralizações para determinação de idades precisas foi em parte prejudicada pelas razões $\mathrm{Sm} / \mathrm{Nd}$ muito baixas (<0.15, à exceção das granadas de Brejuí e Bodó) resultando em limitado crescimento de $\mathrm{Nd}$ radiogênico. Em adição, as baixas concentrações em $\mathrm{Sm}$ e $\mathrm{Nd}$ promoveram inclinações muito suaves para as errócronas implicando em erros muito elevados e, por conseguinte, impossibilitando a validação das idades absolutas sem que antes seja feita uma 

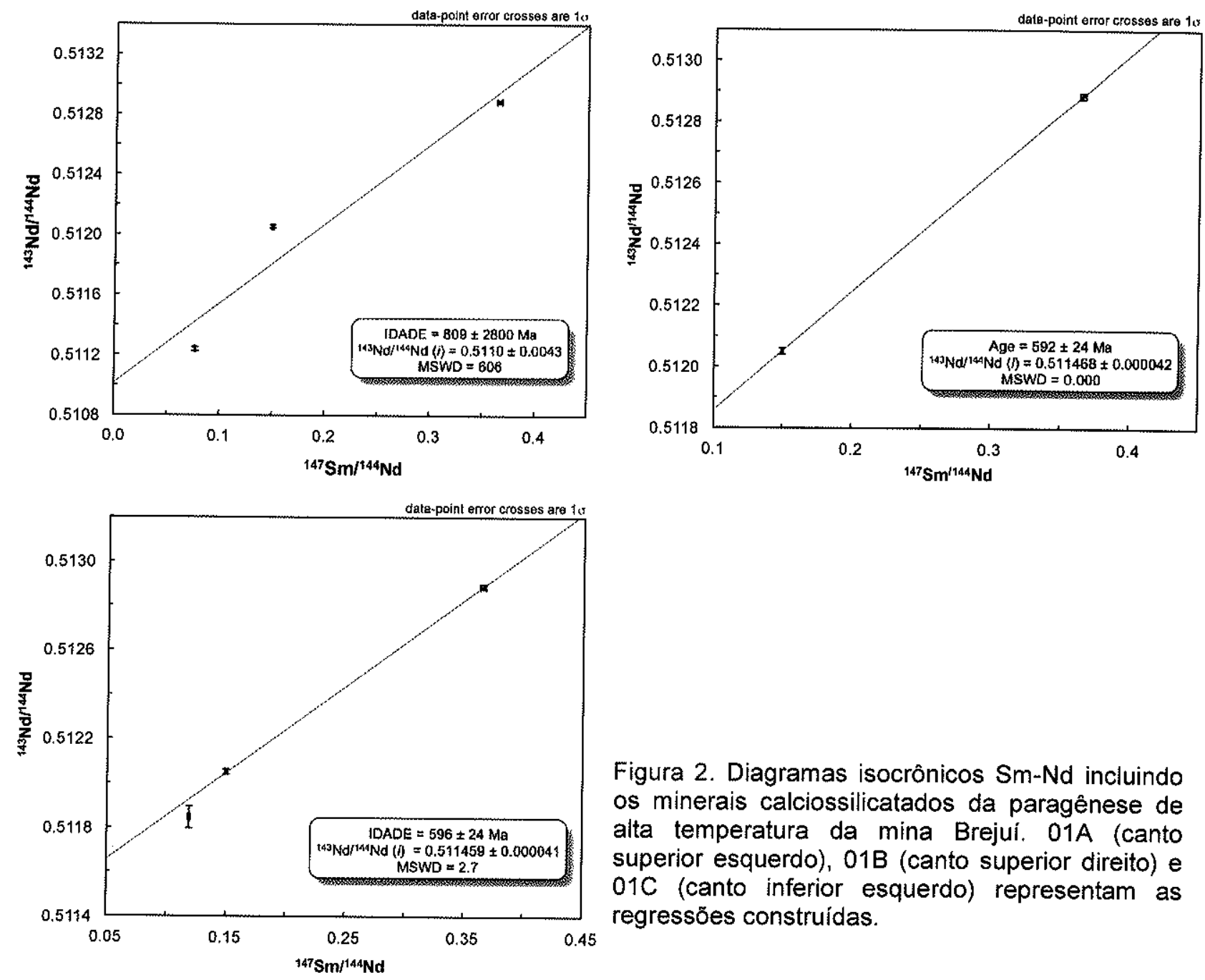

Figura 2. Diagramas isocrônicos $\mathrm{Sm}-\mathrm{Nd}$ incluindo os minerais calciossilicatados da paragênese de alta temperatura da mina Brejui. 01A (canto superior esquerdo), 01B (canto superior direito) e $01 \mathrm{C}$ (canto inferior esquerdo) representam as regressões construidas.
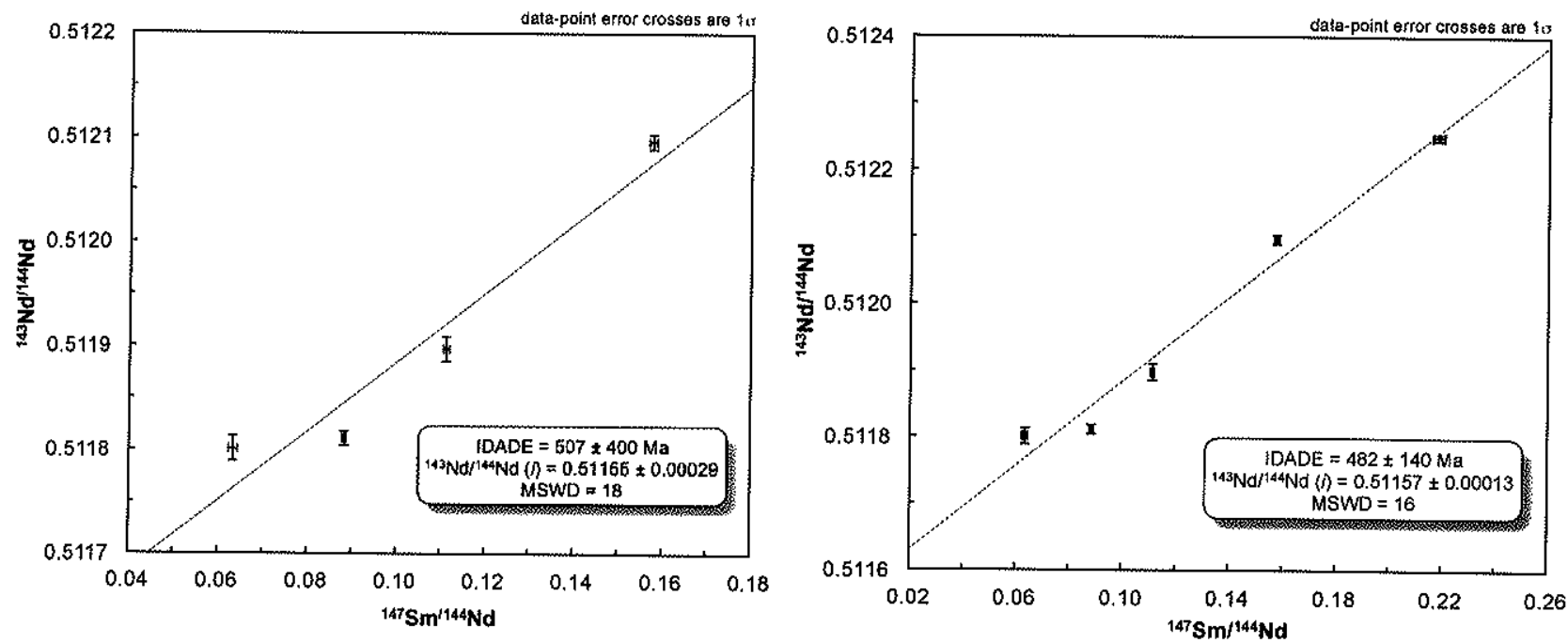

Figura 3. Diagramas isocrônicos $\mathrm{Sm}-\mathrm{Nd}$ incluindo os minerais calciossilicatados da paragênese de baixa temperatura da mina Brejuí. 02A (à esquerda) e 02B (à direita) referem-se às regressões construidas e cuja explicação está no texto. 
comparação com resultados gerados por outros métodos mais precisos. Os erros elevados são ainda maximizados pelo discreto fracionamento entre $\mathrm{Sm}$ e $\mathrm{Nd}$ resultando em estreito espalhamento entre as razões ${ }^{147} \mathrm{Sm} /{ }^{144} \mathrm{Nd}$ das fases minerais em cada paragênese.

\subsection{Isócronas Sm-Nd para as paragêneses de alta e baixa temperatura na mina Bonfim}

As paragêneses de minerais calciossilicatados na mina Bonfim são distintas daquelas em Brejuí e Bodó. Anfibólio e piroxênio são consideradas fases minerais formadoras da paragênese de alta temperatura, enquanto que clinozoisita e scheelita representam as fases analisadas da paragênese de baixa temperatura (calcita não forneceu sinal analítico para detecção de sua composição isotópica). Para a paragênese de alta temperatura o único exercício possível seria considerar uma "isócrona de dois pontos" entre anfibólio e piroxênio visto que titanita e granada (também presente na paragênese) não puderam ser satisfatoriamente purificadas a partir das amostras de mão, sempre com marcante contaminação com outras fases cálcicas. Mesmo sem potencial interpretativo, a isócrona traçada com anfibólio e piroxênio resultou em uma idade de $678 \pm 41 \mathrm{Ma}$ (Fig. 4). Já a isócrona de dois pontos entre clinozoisita e scheelita forneceu idade negativa.

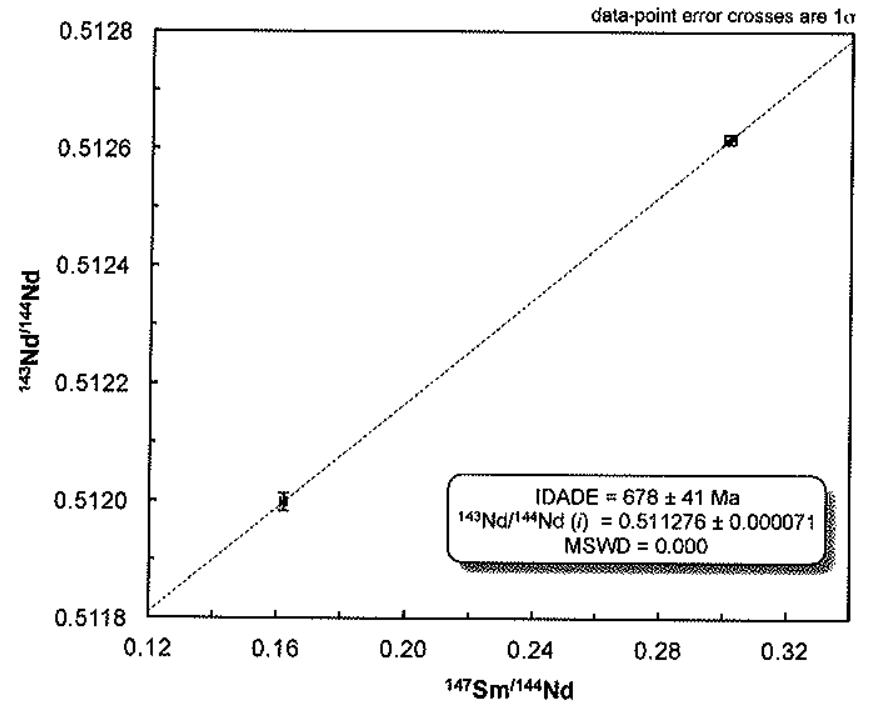

Figura 4. Diagrama isocrônico $\mathrm{Sm}-\mathrm{Nd}$ incluindo anfibólio e piroxênio da paragênese de alta temperatura da mina Bonfim.

\subsection{Isócronas $\mathrm{Pb}-\mathrm{Pb}$ por lixiviação}

Os dados $\mathrm{Pb}-\mathrm{Pb}$ foram obtidos por lixiviação sequencial e considerados, a priori, na construção de isócronas. O primeiro exercício foi considerar isócronas individuais para cada mineral, definidas pelo alinhamento de todas as alíquotas de lixiviação $(L 1, L 2, \ldots, L n)$ obtidas. 
A premissa para esse tipo de exercício é considerar que se há o alinhamento de todos os pontos analíticos, o mineral deve ter se comportado como sistema fechado, e ser livre de inclusões que possam alterar sua composição isotópica primária. O alinhamento ideal (isócrona) é considerado quando o parâmetro MSWD $\leq 2,5$ para $95 \%$ confiança dos dados (Brooks et al.,1972). Para qualquer método isocrônico, o MSWD é considerado a melhor expressão para definir o grau de dispersão do conjunto de dados analíticos. Logo, as regressões com MSWD mais elevado que o limite de 2,5 serão consideradas errócronas, e a dispersão assumida como variações não-coerentes entre as razões ${ }^{206} \mathrm{~Pb} /{ }^{204} \mathrm{~Pb}$ e ${ }^{207} \mathrm{~Pb} /{ }^{204} \mathrm{~Pb}$ no mineral. Tais variações são principalmente atribuídas a fatores como: (i) presença de $\mathrm{Pb}$ remobilizado de sítios cristalográficos originais para regiões de defeitos estruturais durante eventos térmicos posteriores à sua cristalização, resultando em frações $\mathrm{L} 1 \mathrm{em}$ desequilíbrio com as demais, e/ou (ii) presença de inclusões minerais com composições radiogênicas ou não-radiogênicas, as quais interferem preferencialmente nas composições $L n$ finais (L4 ou L5) ${ }^{1}$. Dada a afinidade do $\mathrm{Pb}$ com $\mathrm{HBr}$, as frações $\mathrm{L} 2$ (e também $\mathrm{L} 3$ da granada) tendem a ser as mais radiogênicas, seguida das frações $\mathrm{L} 3$ cujo ataque é feito com $\mathrm{HNO}_{3}$ concentrado. Essas duas frações são aquelas que geralmente são utilizadas para construção de isócronas internas, uma vez que $\mathrm{L} 1$ e os lixiviados finais são mais afetados por $\mathrm{Pb}$ anômalo (não-radiogênico).

\subsubsection{Mina Brejuí}

O primeiro exercício feito com os dados isotópicos gerados por lixiviação por etapas dos minerais calciossilicatados permitiram observar uma pequena faixa de variação das razões ${ }^{206} \mathrm{~Pb} /{ }^{204} \mathrm{~Pb},{ }^{207} \mathrm{~Pb} /{ }^{204} \mathrm{~Pb}$ e ${ }^{208} \mathrm{~Pb} /{ }^{204} \mathrm{~Pb}$ para a maioria destes. Notadamente epidoto e vesuvianita mostram marcante 'homogeneidade' composicional, com variação entre as frações não superior a $10-12 \%$, o que também é observado para anfibólio quando consideradas apenas as alíquotas L1, L3 e L4 (L2 é 20-40\% mais radiogênicas que as demais). Scheelita também mostra frações muito homogêneas, excluindo $L 1$ que é moderadamente radiogênica com respeito às outras. Piroxênio e granada apresentam maiores flutuações das razões entre os lixiviados garantindo maior espalhamento e inclinação de suas isócronas internas.

Considerando a homogeneidade mencionada, e levando em conta que a maior precisão das idades pressupõe amplo espalhamento das razões isotópicas dos pontos analíticos, foram construídas isócronas internas apenas para piroxênio e granada, os quais estão relacionados à paragênese de alta temperatura.

Para piroxênio nota-se que a fração L4 é a menos radiogênica sugerindo a ausência de inclusões de fases ricas em $\mathrm{Pb}$, enquanto que $\mathrm{L} 2$ é destacadamente a fração mais radiogênica

\footnotetext{
${ }^{1}$ As inclusóes são principalmente afetadas pelos ataques com ácidos fortes, utilizados durante as últimas etapas de dissoluçăo.
} 
como resultado da forte retenção de $\mathrm{Pb}$ ao ácido bromídrico $(\mathrm{HBr})$ usado nesta etapa da dissolução. Apesar do amplo espalhamento das razões uranogênicas e torogênicas, a idade obtida foi de $480 \pm 330 \mathrm{Ma}$, com MSWD (=6) e erro muito elevados provavelmente devido à propagação dos erros analíticos individuais especialmente das frações L2 e L3 (Fig. 5A). Ao contrário, a isócrona interna para as frações de lixiviados da granada resultou do bom ajuste entre os pontos analíticos, muito embora com erro igualmente elevado; a idade calculada foi de $564 \pm 120 \mathrm{Ma}$ (MSWD = 0,08; Fig. 5B).
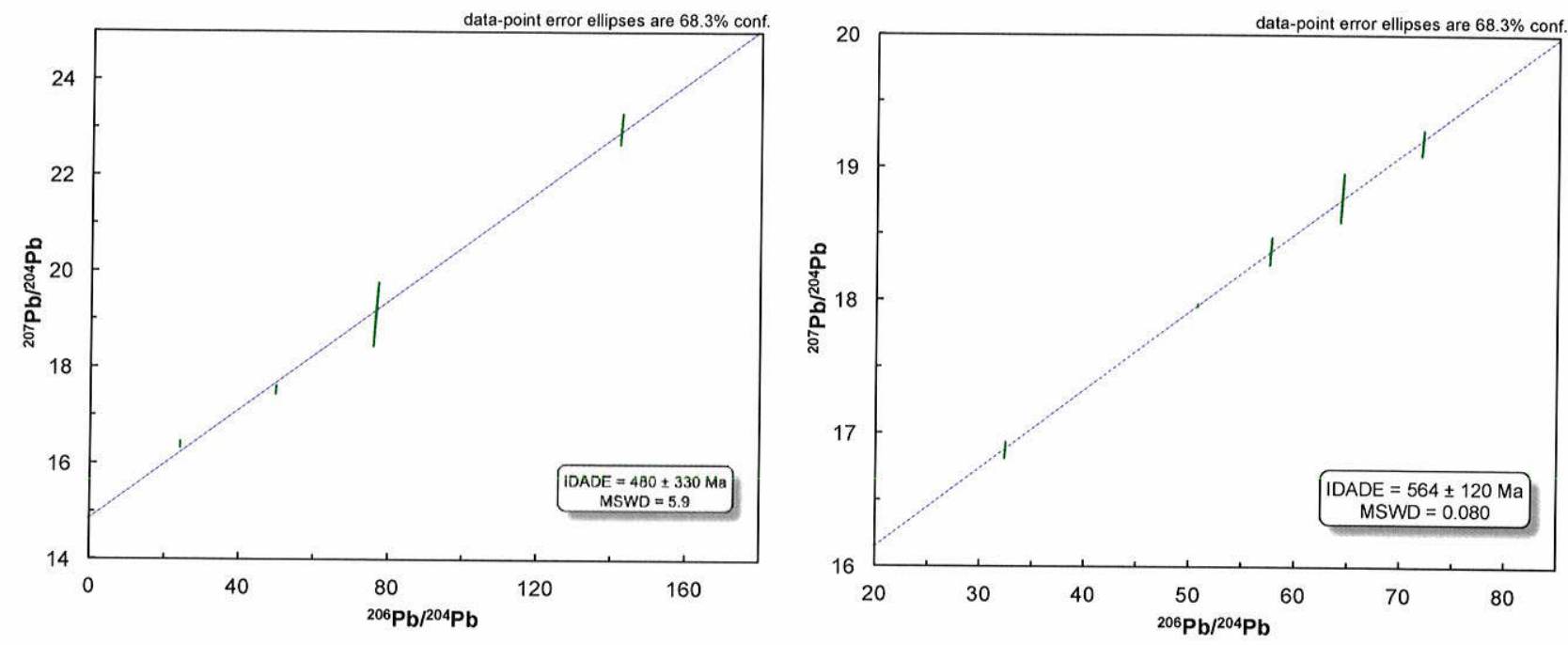

Figura 5. Diagramas isocrônicos ${ }^{206} \mathrm{~Pb} /{ }^{204} \mathrm{~Pb}$ versus ${ }^{207} \mathrm{~Pb} /{ }^{204} \mathrm{~Pb}$ para as frações de lixiviado $\mathrm{L} 1$ a $\mathrm{L} 4$ obtidas de piroxênio ( $\mathrm{A}$ - à esquerda) e granada ( $\mathrm{B}$ - á direita).

Quatro exercícios foram feitos adotando isócronas L2, em geral resultando em bom ajuste entre os pontos analíticos, mas em todos os casos com erros elevados associados às idades calculadas. O primeiro exercício incluiu todos os minerais analisados, de baixa e alta temperatura, resultando em uma idade de $434 \pm 64 \mathrm{Ma}$ (MSWD = 3,1; Fig. 6A). Excluindo piroxênio e molibdenita, os pontos analíticos restantes se ajustaram melhor, fornecendo uma idade mais realística, em $553 \pm 180 \mathrm{Ma}$ (MSWD =0,15; Fig. 6B). Ainda, consideramos isoladamente os minerais de alta (piroxênio, anfibólio, granada) e de baixa (epidoto, vesuvianita, calcita, scheelita e molibdenita) temperatura. Em ambas as tentativas as idades calculadas não parecem coerentes com o cenário regional, sendo de $406 \pm 210 \mathrm{Ma}$ para a paragênese progressiva (Fig. 6C) e $738 \pm 79$ Ma para a paragênese retrogressiva (Fig.6D). 

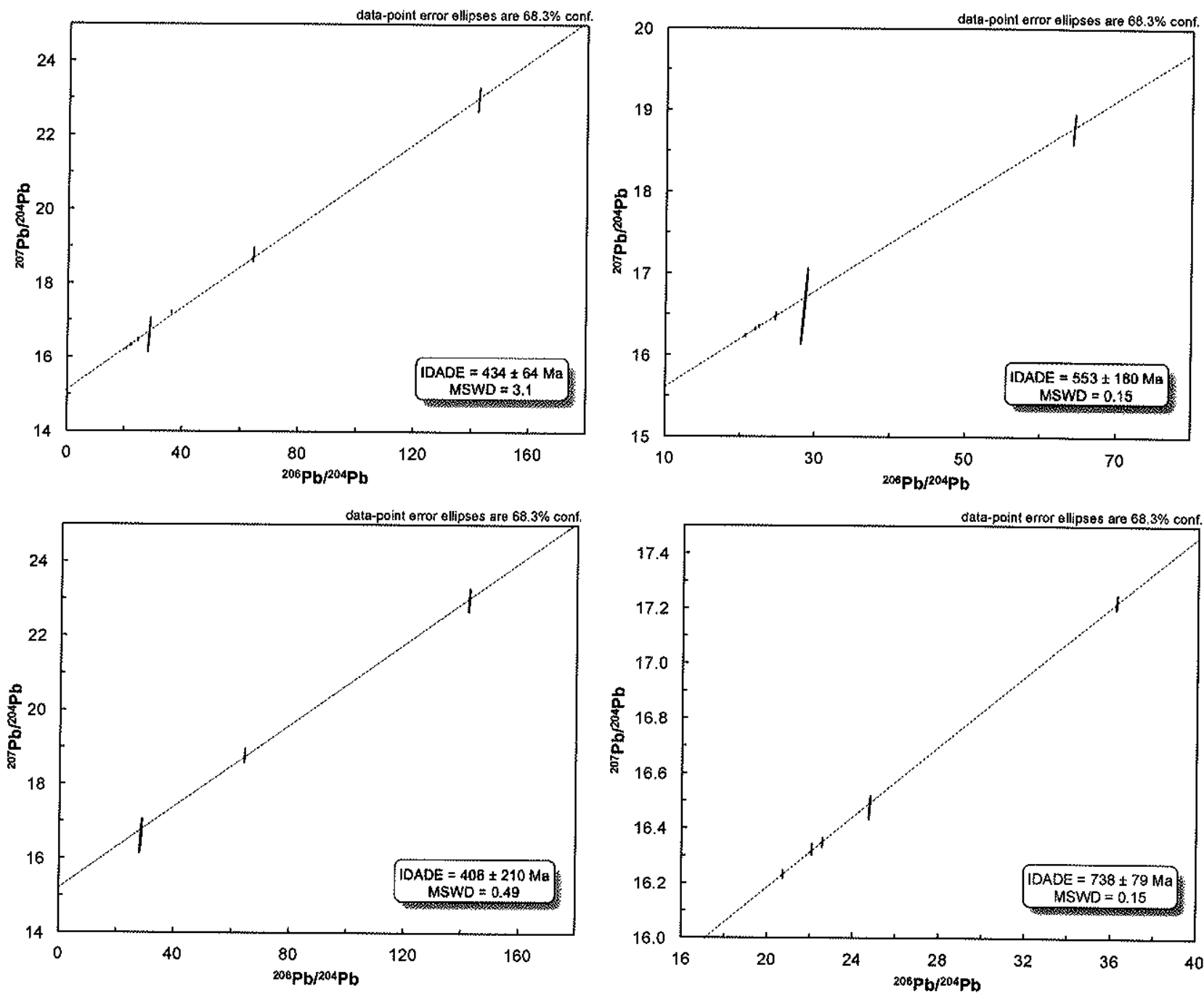

Figura 6. Diagramas isocrônicos ${ }^{206} \mathrm{~Pb} /{ }^{204} \mathrm{~Pb}$ versus ${ }^{207} \mathrm{~Pb} /{ }^{204} \mathrm{~Pb}$ para a fração $\mathrm{L} 2$ da mina Brejuí obtidas a partir de: $A$, todos os minerais (canto superior à esquerda); $B$, excluindo piroxênio e molibdenita (canto superior à direita); $C$, minerais de alta temperatura (canto inferior à esquerda) e $D$, minerais de baixa temperatura (canto inferior à direita).

\subsubsection{Mina Bodó}

As composições isotópicas de $\mathrm{Pb}$ das frações de lixiviado obtidas para os minerais calciosilicatados da mina Bodó são ainda mais homogêneas se comparadas àquelas dos minerais de Brejuí, impedindo qualquer tentativa de obter idades isocrônicas internas precisas. De todos apenas vesuvianita mostra uma certa dispersão entre $L 1$ a $L 4$, mais ainda pequena para garantir erros baixos (errócrona $689 \pm 440 \mathrm{Ma}$; $M S W D=14$, gráfico não ilustrado).

Da mesma forma que para a mina Brejuí a fração L2 foi escolhida para a construção de isócronas individuais de alta (piroxênio, anfibólio, granada) e de baixa (epidoto, vesuvianita, calcita, scheelita e molibdenita) temperaturas. Se incluídos todos os pontos, a idade calculada é espúria em $1163 \pm 1400$ Ma (MSWD = 428), induzida pela forte dispersão da composição isotópica de piroxênio (Fig. 7A). Se piroxênio é excluído, os demais pontos analíticos se 
ajustam razoavemente definindo uma errócrona com idade $495 \pm 210 \mathrm{Ma}$ (MSWD = 7; Fig. 7B). Idades espúrias também foram obtidas quando considerada isoladamente a paragênese de alta temperatura, incluindo ou não piroxênio que tem a composição isotópica mais destoante. Ao contrário, os minerais da paragênese de baixa temperatura definem uma errócrona semelhante com a isócrona total, com idade em $500 \pm 210 \mathrm{Ma}$ (MSWD = 8,9; Fig. 7C).

\subsubsection{Mina Bonfim}

Quando observadas as composições isotópicas de $\mathrm{Pb}$ das frações de lixiviado obtidas para os minerais calciosilicatados da mina Bonfim nota-se maior variação dos valores se comparadas com àquelas dos minerais de Brejuí e Bodó. Mesmo assim, todas as tentativas de construção de isócronas internas culminaram em idades anomalamente antigas e/ou erros significativamente elevados. Ainda, para a mina Bonfim a fração $L 3$ apresentou as cmposições mais radiogênicas para todos os minerais analisados, motivo pelo qual foi preferida para a construção das isócronas paragenéticas. A isócrona ajustada para todos os pontos analíticos forneceu idade anomalamente jovem de $213 \pm 300 \mathrm{Ma}$ (MSWD $=2,1$; Fig. $8 \mathrm{~A}$ ), resultado semelhante também fornecido se piroxênio (com erros individuais elevados) for excluido da regressão.

Anfibólio e piroxênio juntos alinharam-se com inclinação reversa dando idade negativa e impedindo estimativa para a paragênese de alta temperatura. Já os minerais de baixa temperatura se ajustaram muito bem em uma isócrona de $539 \pm 320 \mathrm{Ma}$ (MSWD =0,61; Fig. 8B), apenas excluindo a composição isotópica da molibdenita da regressão.

\subsection{Idades Re-Os em molibdenitas}

De forma geral as molibdenitas das três minas estudadas têm concentrações de Re que se enquadram dentro de intervalos normalmente esperados, sem quaisquer particularidades que possam ser destacadas. Isso indica que os resultados obtidos seguramente representam idades de cristalização visto que a observação microscópica sugere uma única geração de molibdenita em cada uma das amostras estudadas.

As análises mostraram teores de Re variáveis entre 7,5 ppm (Bodó) e 112 ppm (Brejuí) associadas com quantidades de Os comum desprezíveis, indicando que todo Os medido é radiogênico produto do decaimento de Re. Uma pequena fração de Os comum foi detectada na amostra de molibdenita da mina Bonfim provavelmente devido à pequenas inclusões de pirita e/ou calcopirita. Esse valor foi usado para corrigir a idade obtida para a amostra mesmo 
representando menos de $5 \%$ da quantidade de ${ }^{187}$ Os radiogênico medido. Face a essa particularidade, uma replicata foi tomada para análise (usando um segundo concentrado de molibdenita coletado na mesma amostra) e a idade obtida tem excelente coerência com a primeira, confirmando que a presença incipiente de Os comum não é um fator importante na determinação da idade.

As idades determinadas foram $550 \pm 2$ Ma para a molibdenita da mina Brejuí, $510 \pm 2$ Ma para a molibdenita da mina Bodó e $525 \pm 2$ Ma para a molibdenita coletada no skarn da mina Bonfim.
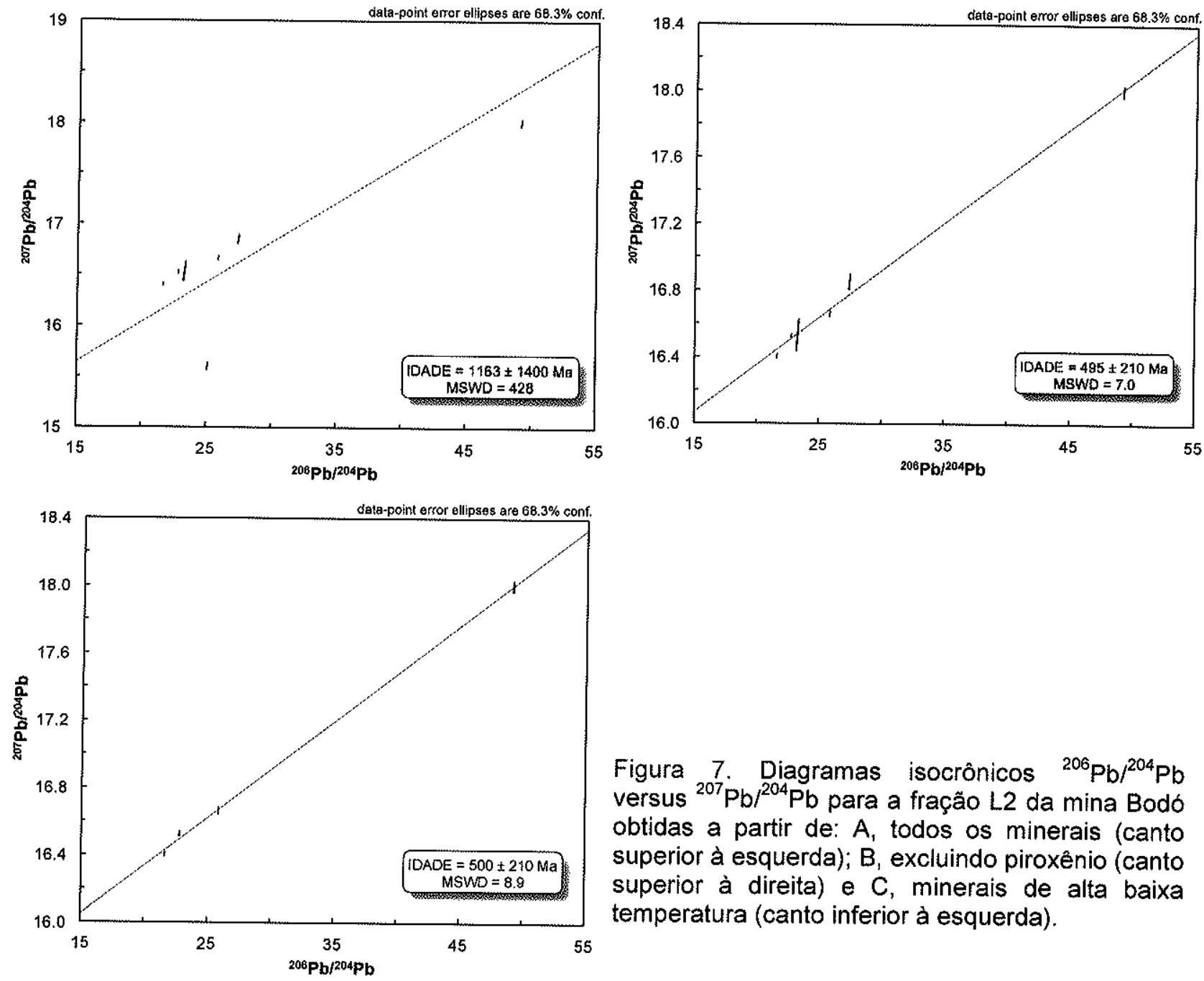

Figura 7. Diagramas isocrônicos ${ }^{206} \mathrm{~Pb} /{ }^{204} \mathrm{~Pb}$ versus ${ }^{207} \mathrm{~Pb} /{ }^{204} \mathrm{~Pb}$ para a fração $L 2$ da mina Bodó obtidas a partir de: $A$, todos os minerais (canto superior à esquerda); $B$, excluindo piroxênio (canto superior à direita) e $C$, minerais de alta baixa temperatura (canto inferior à esquerda). 

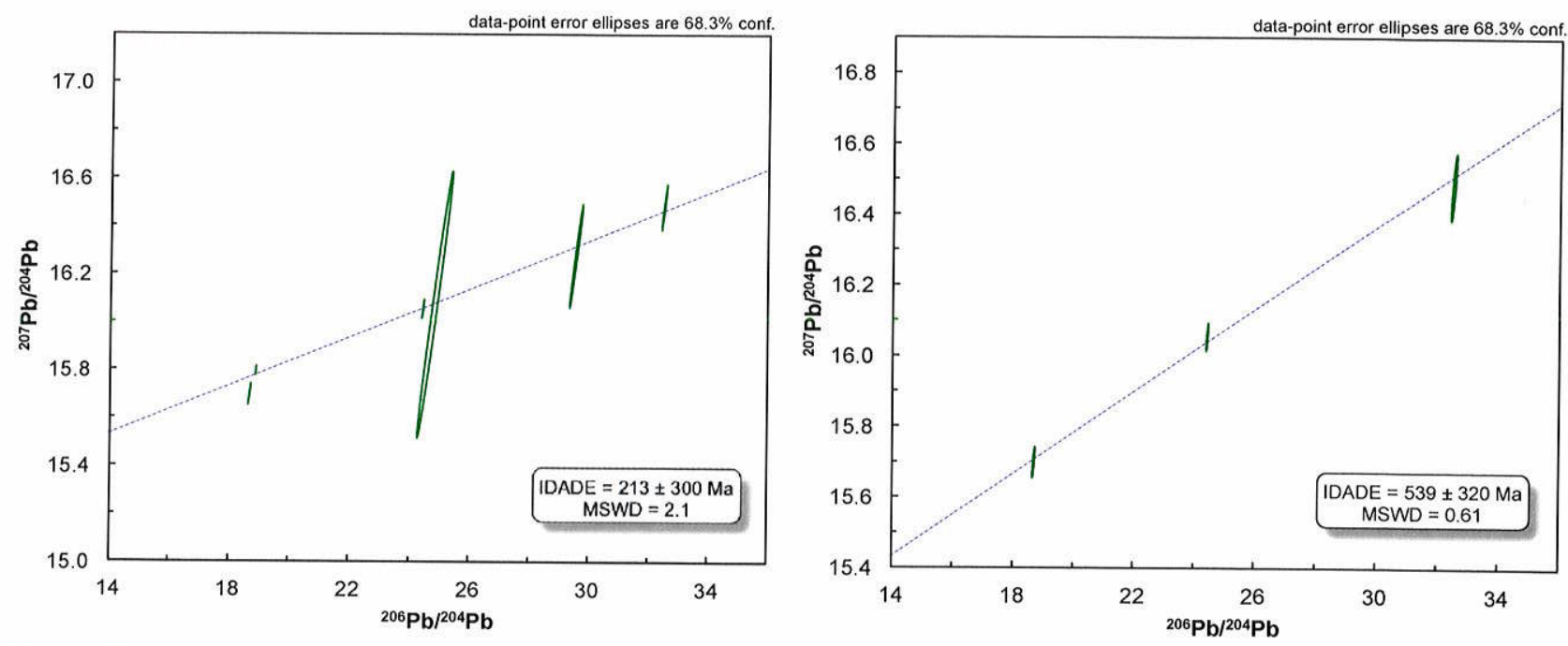

Figura 8. Diagramas isocrônicos ${ }^{206} \mathrm{~Pb} /{ }^{204} \mathrm{~Pb}$ versus ${ }^{207} \mathrm{~Pb} /{ }^{204} \mathrm{~Pb}$ para a fração $\mathrm{L} 3$ da mina Bonfim obtidas a partir de: $\mathrm{A}$, todos os minerais (à esquerda) e B, minerais de baixa temperatura (à direita).

\subsection{Idades U-Pb SHRIMP em zircão para os plútons de Acari, Totoró, Picuí e Cerro Corá}

As idades $\mathrm{U} / \mathrm{Pb}$ dos fácies petrográficos que constituem os plútons de Acari e Totoró foram apresentadas no capítulo anterior como parte do artigo sobre o timing de metamorfismo de alto grau brasiliano. As idades referem-se aos granito porfirítico e granito fino do plúton de Acari e formam definidas em c. $577,7 \pm 4,5 \mathrm{Ma}$ (fácies porfirítico) e c. $572,1 \pm 4,6 \mathrm{Ma}$ (fácies granítico fino). As idades obtidas para o plúton de Totoró são mais antigas, de $597 \pm 5,7 \mathrm{Ma}$ (fácies gabro-norítico), $595 \pm 3,4 \mathrm{Ma}$ (fácies diorítico) e $591 \pm 3,8 \mathrm{Ma}$ (fácies granito porfirítico).

Os zircões extraídos da amostra CCOR-1 (granito Cerro Corá) são prismáticos, com tamanhos entre 100 e $250 \mu \mathrm{m}$, e razões comprimento:largura de aproximadamente 2:1. Os grãos são claros, com inclusões e microfraturas pouco frequentes e zonação tipicamente ígnea. Quatorze análises foram realizadas em grãos distintos, a maioria semi-concordante (ligeiramente reversos), com idades ${ }^{206} \mathrm{~Pb} /{ }^{238} \mathrm{~Pb}$ entre 500 e $553 \mathrm{Ma}$, com média de 526,6 \pm 7,7 Ma (MSWD = 0,76) (Fig. 9).

Os zircões da amostra PI-1 (granito Picuí) são prismáticos, com tamanhos entre $150 \mathrm{e}$ $300 \mu \mathrm{m}$, e razões comprimento:largura variando entre 2:1 e 3:1. Os grãos têm aspecto semelhante à amostra CCOR-1, aparentemente livres de fraturas e núcleos e com zonação tipo oscilatória. Vinte e uma análises foram realizadas em grãos distintos, mas apenas treze foram consideradas no cálculo da idade Concórdia (\#3.1, \#4.1, \#5.1, \#7.1, \#8.1, \#10.1, \#11.1, \#12.1, $\# 14.1$, \#16.1, 17.1, \#18.1, \#21.1) que forneceu idade de 548.6 \pm 3.6 Ma coincidente com a idade média ${ }^{206} \mathrm{~Pb} /{ }^{238} \mathrm{~Pb}$ de $548,0 \pm 4,8 \mathrm{Ma}$ (Fig.9). 

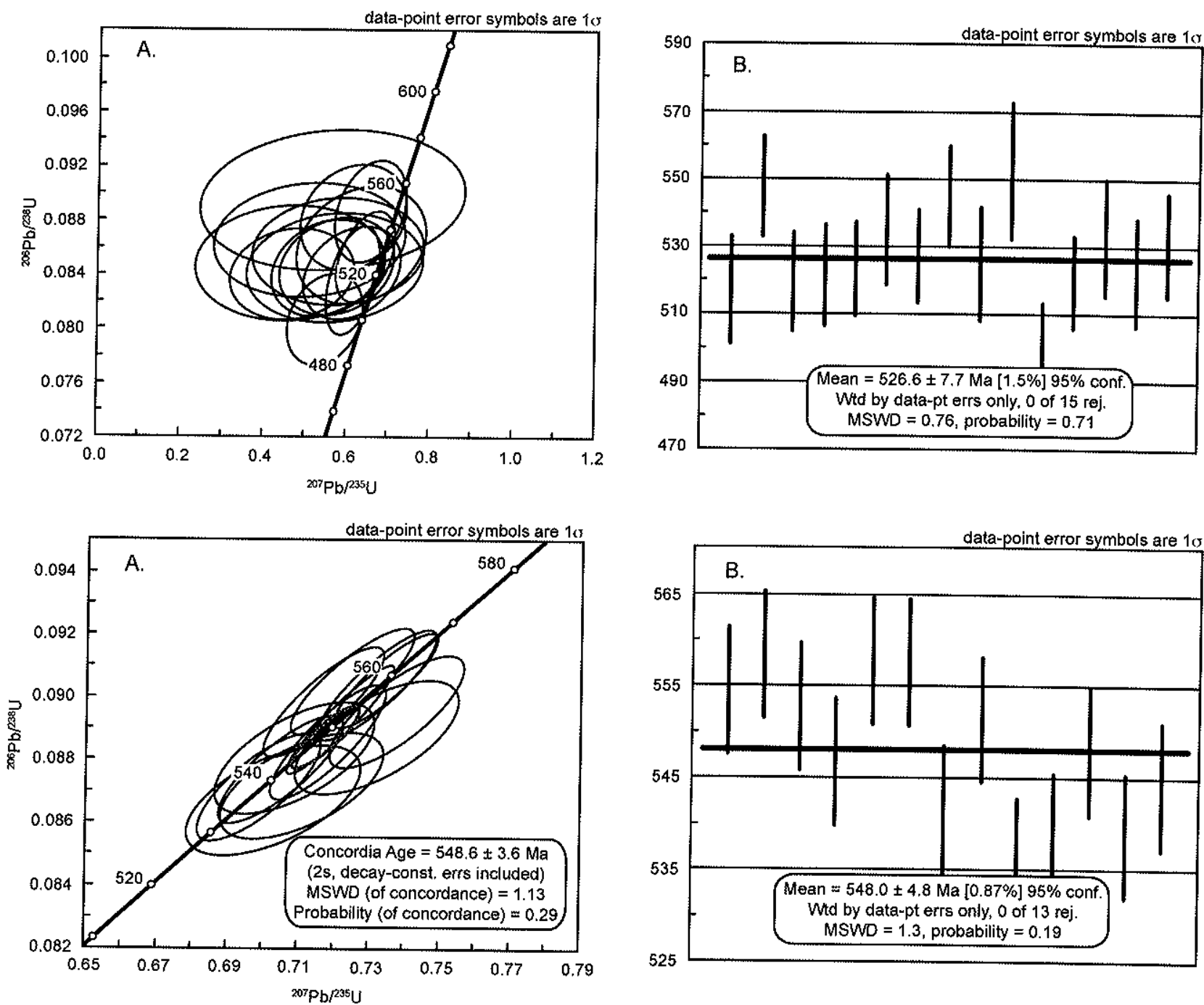

Figura 9. Diagramas Concórdia e histograma de idades médias ${ }^{206} \mathrm{~Pb} /{ }^{238} \mathrm{U}$ para os granitos de Cerro Corá ( $A$ e $B$, superior) e Picuí ( $A$ e $B$, inferior).

\section{CONCLUSÃO}

Os objetivos propostos neste projeto incluíram a obtenção de informações que pudessem amparar a correlação temporal das mineralizações de W-Mo na Faixa Seridó com a importante granitogênese na região. O foco principal foi a datação de depósitos minerais considerados os mais importantes da faixa - Brejuí, Bodó, e Bonfim. É sabido que a determinação de idades radiométricas precisas em sistemas hidrotermais não é uma tarefa simples visto a não-rara mobilidade dos elementos químicos, em especial quando os depósitos sofrem episódios hidrotermais/mineralizantes superpostos. Assim, as tentativas de aplicar os métodos $\mathrm{Sm}-\mathrm{Nd}$ e $\mathrm{Pb}-\mathrm{Pb}$ foram válidas para uma primeira aproximação de como esses sistemas isotópicos podem comporta-se nesses ambientes. Apesar dos resultados pouco estimulantes, novas análises $\mathrm{Sm}-\mathrm{Nd}$ e $\mathrm{Pb}-\mathrm{Pb}$ poderão ser realizadas em outras fases minerais (plagioclásio e titanita, por exemplo) que não puderam ser incluídas neste trabalho, 
principalmente em função das dificuldades em separar e purificar concentrados a partir de amostras de mão tão heterogêneas. Com isso poderiamos aumentar o número de pontos analíticos considerados nas regressões na tentativa de alcançar maior espalhamento e reduzir os erros intrínsecos às idades obtidas.

De qualquer forma, podemos concluir que os resultados Sm-Nd obtidos são fortemente influenciados pelas baixas concentrações de terras raras nos minerais calciossilicatados que, não impossivel, podem estar relacionadas às igualmente baixas concentrações detectadas nas rochas hospedeiras, notadamente nos mármores. Essa informação está disponível na Tese de Doutorado de J. Salim (1993), desenvolvida exclusivamente para caracterizar as paragêneses minerais na mina Brejuí e definir sua origem. Quanto às composições isotópicas de $\mathrm{Pb}$ acreditamos que a homogeneidade generalizada entre as frações de lixiviado observadas na maioria dos minerais deve refletir "equilíbrio isotópico" induzido pela interação generalizada de fluidos com baixas razões U/Pb.

Apesar das limitações dos métodos $\mathrm{Sm}-\mathrm{Nd}$ e $\mathrm{Pb}-\mathrm{Pb}$ o objetivo principal do projeto foi atingido com as idades Re-Os nas molibdenitas que ocorrem associadas à scheelita. Os resultados são de excelente qualidade e apontam para três episódios mineralizantes separados no intervalo entre c. 555 - $510 \mathrm{Ma}$, e que inegavelmente estão associados a pulsos recorrentes de magmatismo ácido tardi-brasiliano na Faixa Seridó. 


\section{CAPÍTULO 5}

Neste capítulo são apresentados alguns comentários sobre os resultados obtidos nesta Tese de Livre-Docência. 
Esta tese reúne um conjunto de novos dados geocronológicos obtidos de rochas metaplutônicas e graníticas da Faixa Seridó que, de forma integrada, permitem estabelecer uma sequência cronológica para vários episódios magmáticos que afetaram a região desde o Paleoproterozoico até o Cambriano, num intervalo de tempo de quase dois bilhões de anos. A análise e discussão dos dados estão apresentados individualmente em cada capítulo. Aqui aprasentaremos uma síntese dos resultados, ressaltando algumas questões ainda em aberto que deverão ser exploradas em investigações futuras.

\section{A. O Complexo de Embasamento}

Os dados apresentados no Capítulo 2 mostram uma forte coincidência entre as idades $\mathrm{U}-\mathrm{Pb}$ SHRIMP obtidas para os augen gnaisses $\mathrm{G}_{2}$ e aquelas atualmente disponíveis para os ortognaisses do Complexo Caicó (Rb-Sr, $\mathrm{Pb}-\mathrm{Pb}, \mathrm{U}-\mathrm{Pb} / \mathrm{TIMS}$ ), definindo um intervalo em c. 2,25 - 2,15 Ga. Essa coincidência torna inválido o desmembramento no tempo da suite $\mathrm{G}_{2}$ com respeito ao complexo de embasamento do Seridó, o que levanta o problema do substrato para a intrusão dos magmas progenitores dessas rochas no Paleoproterozoico.

A proposta de um conjunto litológico mais antigo que o Complexo Caicó foi originalmente defendida por Ebert (1970) para rochas metamáficas que ocorrem na região de São Vicente-Florânia (RN), denominadas Grupo São Vicente. Isócronas Rb-Sr dessas rochas forneceram idades em torno de 2,7 Ga (Brito Neves et al., 1975; Pessoa, 1979), mas que foram subsequentemente invalidadas face a obtenção de idades U-Pb em zircão entre 2,21 - 2,15 Ga (Dantas, 1992; Hackspacher et al., 1982). Os dados U-Pb mostraram, portanto, que aparentemente não havia diferenças geocronológicas significativas entre o Grupo São Vicente e os ortognaisses do Complexo Caicó. No entanto, fica evidente a necessidade de reconhecer um substrato mais antigo para as intrusões riacianas que, supomos, pode não ter sido ainda identificado devido às limitações analíticas inerentes aos métodos geocronológicos utilizados como Rb-Sr e U-Pb TIMS. Nesse último caso, acreditamos que os zircões analisados por diluição isotópica podem ter sido recristalizados por eventos tectonotermais mais jovens (Brasiliano, sobretudo) que, numa análise multigrãos, certamente influenciam no rejuvenescimento da idade. Esse tipo de padrão foi observado em vários zircões dos augen gnaisses estudados neste trabalho.

Unidades mais antigas que as metaplutônicas que definem o Complexo Caicó foram encontradas na sequência de gnaisses bandados na região de Santa Luzia (ver Cap. 2). Essa unidade compreende ortognaisses granodioríticos a tonalíticos, leucognaisses e anfibolitos, 
incluindo localmente lentes de rochas supracrustais tais como mármores e micaxistos. Os ortognaisses granodioríticos forneceram idade de c. $2,4 \mathrm{Ga}$, enquanto diques de metaleucogabro intrusivos na sequência bandada forneceram uma idade similar aos augen gnaisses $G_{2}$, em c. 2,2 Ga. Sequências siderianas $(2,5-2,3 \mathrm{Ga})$ foram ainda identificadas no domínio Médio Coreaú (Fetter, 1999; Fetter et al., 2000; Santos et al., 2009), na região de Lajes (RN; Dantas et al., 2008) e, mais recentemente, na porção oeste do Lineamento Patos na região de Lavras da Mangabeira (Bautista et al., 2011). Esse conjunto de resultados sugere que o significado geológico das sequências tipo Santa Luzia/São Vicente para a formação do complexo de embasamento da Faixa Seridó requer, portanto, uma nova abordagem agora possível com o desenvolvimento de análises pontuais.

\section{B. O Plutonismo Neoproterozoico}

Outra questão em aberto com respeito à história geológica precambriana da Faixa Seridó é a definição precisa da idade do magmatismo brasiliano e, por extrapolação, da deformação/metamorfismo associados. Nessa região, a granitogênese está condicionada ao funcionamento de zonas de cisalhamento transpressionais/transtensionais de direção NE, as quais se conectam em perfeita continuidade cinemática à terminação em splay do lineamento Patos, E-W. As condições metamórficas que regem esse controle estrutural são explicitadas pela ocorrência de setores com intensa migmatização do embasamento gnáissico (e menos frequente, das supracrustais) atestando a alta temperatura $\left(>650^{\circ} \mathrm{C}\right)$ prevalente durante a orogenia Brasiliana na região. Em campo, essa migmatização é notada pelo desenvolvimento de estruturas nebulíticas a anatexíticas que, em escala microscópica, são refletidas pela recristalização pervasiva de zircões mais antigos (arqueanos a paleoproterozoicos) que sobreviveram parcialmente a esse processo.

A correlação estrutural e genética entre granitogênese e migmatização brasilianas na Faixa Seridó foi abordada comparando-se a trama magnética dos plutons de Acari e Totoró com o aquela do anatexito (domo) de Santa Luzia e de suas idades U-Pb (zircão). Esses corpos representam registros de fusão em níveis crustais (também manto litosférico) distintos, ocorrendo em continuidade espacial ao longo de uma das mais expressivas zonas de cisalhamento transcorrente/transpressionais de alto strain mapeadas na faixa (regionalmente referida como zona de cisalhamento Currais Novos - Serra dos Quintos).

Os dados apresentados e discutidos no Capítulo 3 mostram que os padrões de tramas magnéticas obtidos para o plúton de Acari e para o anatexito de Santa Luzia são análogos, atestando sua contemporaneidade com respeito à cinemática destral da zona de cisalhamento caracterizada por foliação e lineação alinhadas segundo a direção de máximo achatamento do 
elipsóide de strain regional. Essa contemporaneidade é fortalecida pela correspondência cronológica entre a cristalização de Acari e a migmatização se comparadas as idades U-Pb obtidas em c. $575 \mathrm{Ma}$. Quando combinados, os resultados nos mostram que deformação dúctil da crosta, magmatismo bimodal e metamorfismo de alto grau foram eventos sincrônicos e pervasivos, caracterizando a principal fase da evolução tectonotermal brasiliana na Faixa Seridó.

A idade do plúton de Totoró, por sua vez, é mais antiga apontando para um episódio magmático precoce em c. $595 \mathrm{Ma}$, também de natureza bimodal com granitos cálcio-alcalinos alto-K em estreita relação de contemporaneidade com dioritos e gabros shoshoníticos. significado geológico desse evento deve ser explorado em trabalhos futuros, principalmente quanto à sua representatividade dentro do magmatismo brasiliano. Outros corpos de natureza shoshonítica (Quixaba, Cardoso, Riachão) e alcalina (Serra Negra do Norte) poderiam ser candidatos a essa manifestação magmática precoce dadas suas isócronas $\mathrm{Rb}-\mathrm{Sr}$ e idades U$\mathrm{Pb}$ em c. $600 \mathrm{Ma}$, ainda passíveis de refinamento (Hackspacher et al., 1987; Campos et a.l., 2002; A.C. Galindo, com. verbal).

\section{O Plutonismo na Transição Neoproterozoico-Cambriano}

O estudo do magmatismo na Faixa Seridó necessariamente leva aos eventos mineralizantes reconhecidos na região. Do ponto de vista metalogenético, a orogênese Brasiliana proveu a Faixa Seridó com várias ocorrências minerais das quais destacam-se a Província Scheelitífera e a Província Pegmatítica do Seridó. Abrangem juntas uma área de aproximadamente $30.000 \mathrm{~km}^{2}$ nos limites da qual são cartografadas mais de 700 ocorrências de depósitos de $\mathrm{W}$ em scheelita (também Mo, Cu e Fe) hospedados em skarns e algumas centenas de corpos pegmatíticos conhecidos, grande parte mineralizados em $\mathrm{Be}, \mathrm{Li}, \mathrm{Nb}$ e $\mathrm{Ta}$. Também cita-se as ocorrências de veios de quartzo contendo Au associados à zonas de cisalhamento regionais. O artigos de Araújo et al. (2001) e Souza Neto et al. (2008) trazem sínteses sobre aspectos importantes de ambas províncias minerais.

As mais importantes ocorrências de $W(-M o)$ são as minas Bodó $(61 \%$ da reserva da província) além de Brejuí, Barra Verde, Boca de Lage e Zangarelhas que juntas correspondem a um único depósito mineral. Dados petrogenéticos disponíveis sobre esses depósitos são principalmente encontrados em teses e dissertações não publicadas, incluindo a Tese de Doutorado de José Salim (1993) que realizou estudo detalhado de caracterização e quimismo mineral das assembléias calciosilicatadas que estão representadas na mina Brejuí, e a de João Adauto Souza Neto (1999) que abordou estudo semelhante nas minas Bonfim e Itajubatiba. Seus resultados levam ao estabelecimento de um modelo epigenético de hidrotermalismo 
metasomático onde uma fase fluida dominantemente aquosa seria responsável pela formação de skarns primários (anortita+anfibólio+piroxênio+granada) em condições de temperatura elevada $\left(500^{\circ}-600^{\circ} \mathrm{C}\right)$ e baixa pressão $(3 \mathrm{kbar})$ semelhantes àquelas estimadas para 0 metamorfismo regional (ver Archanjo et al., in press). Em um segundo episódio hidrotermal, fluidos carbônicos a aquosos de baixa salinidade (4 -15 wt\% EqNaCl) teriam modificado a assembléia mineral primária para paragêneses tipo escapolita-vesuvianita, epidoto-phrenita e zeólitas, em condições PT variáveis entre $450^{\circ}-200^{\circ} \mathrm{C} / 2-0,6$ kbar. Essas zonações metassomáticas são feições comuns em outros skarns do mundo (p.ex., Einaudi e Burt, 1982).

Análises petrográficas e dados microtermais realizadas por J. Salim apontam a maior afinidade deposicional da scheelita às condições PT vigentes quando da formação da paragênese hidrotermal epidoto-prehnita $\left(<380^{\circ} \mathrm{C}\right.$ e baixa $\left.\mathrm{aCa}\right)$. Em equilíbrio com scheelita são identificadas molibdenita e também as fases sulfetadas pirita, calcopirita e bornita, indicando condições redutoras de formação para a paragênese secundária. Relações de campo, petrografia detalhada, química mineral e geoquímica multielementar sugerem que essas fases metálicas teriam sido trazidas pela percolação de fluidos canalizados em zonas de cisalhamento, depositados preferencialmente ao longo das interfaces litológicas entre paragnaisses e mármores da Formação Jucurutu, num contexto de evolução claramente epigenética (Salim, 1993; Souza Neto, 1999). Ainda, composições isotópicas $\left(\delta^{18} \mathrm{O}\right)$ em calcitas das paragêneses de baixo grau indicam que a origem desses fluidos é predominantemente magmática, caracterizados por assinatura depletada em ${ }^{18} \mathrm{O}$ (Souza Neto et al., 1999).

A correlação genética entre mineralização e magmagênese pôde ser confirmada a partir da datação direta desses eventos. Neste trabalho, optamos por aplicar os métodos Re-Os em molibdenita dos depósitos Brejuí, Bodó e Bonfim escolhidos por estar entre os maiores e mais bem estudados do ponto de vista petrogenético. Por sua vez, os corpos graníticos foram datados pelo método $\mathrm{U}-\mathrm{Pb}$ in situ em zircão. Os alvos foram os plútons de Acari e Totoró e os leucogranitos tardi-brasilianos Cerro-Corá e Picuí que afloram nas proximidades daqueles depósitos e parecem compartilhar o mesmo contexto estrutural. As idades Re-Os obtidas são precisas e deixam claro que os eventos mineralizantes foram importantes na transição Neoproterozoico-Cambriano, estendendo até próximo à transição Cambriano-Ordoviciano. A mineralização em Brejuí é a mais antiga, depositada em c. 555 - 550 Ma. Esse resultado não permite a correlação direta com a cristalização do plúton de Acari (580 - $570 \mathrm{Ma})$ e, portanto, não poderia balizar o modelo de skarnitização ligada a metamorfismo de contato como preconizado em trabalhos antigos na região. As idades das molibdenitas de Bodó e Bonfim são significativamente mais jovens, em c. 510 e c. 525 Ma e, da mesma forma que para Brejuí, esses resultados não coincidem com as idades obtidas para Acari e Totoró (600 - $590 \mathrm{Ma}$ ).

Até recentemente toda a granitogênese brasiliana (a suite $G_{3}$ de Jardim de Sá et al., 1981) na Faixa Seridó era correlacionada ao pico de deformação/metamorfismo de alta 
temperatura em c. $580 \pm 30 \mathrm{Ma}$. Como já comentado, esse evento tectonometamórfico está agora bem definido em c. 575 Ma pelas datações do plúton de Acari e do migmatito de Santa Luzia. Idades similares foram obtidas em outros corpos ígneos da região, notadamente aqueles que intrudem o embasamento ocidental (São João do Sabugi - Leterrier et al., 1994; Caraúbas, Tourão - Trindade et al., 1999; Catolé do Rocha - Medeiros et al., 2005) e oriental (Serrinha e Monte das Gameleiras - Galindo et al., 2005; Solânea - Guimarães et al., 2005). No entanto, as idades U-Pb obtidas para os leucogranitos de Cerro-Corá e Picuí, apresentados no Capítulo 4, mostram que a granitogênese se estendeu por um período bem mais amplo, com recorrência em pelo menos dois momentos, c. $550 \mathrm{Ma}$ e c. $525 \mathrm{Ma}$. A esses dados somam-se idades de duas intrusões menores - granitos Flores em 545 Ma (Souza et al., 2010) e Capuxu em $541 \pm 4$ Ma (Medeiros et al., 2005), e às idades de vários corpos pegmatíticos em c. 515 - 509 Ma (Araújo et al., 2005; Baumgartner et al., 2006). Se considerados os erros analíticos das idades individuais, a recorrência poderia ser estendida para intervalos entre 552 - $538 \mathrm{Ma}, 534$ - 519 Ma e 516 - $507 \mathrm{Ma}$, ainda assim bem separados no tempo.

Como conclusão, é possível delinear uma história de magmagênese ampla (episódica ou contínua ?) nos domínios da Faixa Seridó e seu embasamento desde o Ediacarano em c. $600 \mathrm{Ma}$ até o Cambriano Superior em c. $510 \mathrm{Ma}$. Os fluidos mais tardios, provenientes das intrusões mais jovens, aparecem como os principais agentes transportadores de metais $(\mathrm{W}, \mathrm{Fe}$, $\mathrm{Cu}$ ) e outros elementos ( $\mathrm{Au}, \mathrm{Be}, \mathrm{Nb}, \mathrm{Ta}, \mathrm{Li})$ formadores dos inúmeros depósitos minerais na região. Assim, a correlação temporal entre granitogênese e mineralização em skarns agora estabelecida na transição Neoproterozoico-Cambriano pode ser usada como indicador potencial na prospecção de novas ocorrências metalogenéticas na Província Borborema e em outras com história geológica similar. 


\section{Referências Citadas}

Almeida, F.F.M., Hasui, Y., Brito Neves, B.B., Fuck, R.A. 1977. Províncias estruturais brasileiras. Atas $8^{\circ}$ Simpósio Geologia do Nordeste: 363-391.

Araújo, M.N.C., Silva, F.C.A., Jardim de Sá, E.F. 2001. Pegmatitic emplacement in the Seridó Belt, northeastern Brazil: late stage kinematics of the Brasiliano orogen. Gondwana Research, 4: 75-85.

Araújo, M.N.C., Vasconcelos, P.M., Silva, F.C.A., Jardim de Sá, E.F., Sá, J.M. $2005 .{ }^{40} \mathrm{Ar} /{ }^{39} \mathrm{Ar}$ geochronology of gold mineralization in Brasiliano strike-slip shear zones in the Borborema Province, NE Brazil. Journal of South American Earth Sciences, 19: 445-460.

Archanjo, C.J., Salim, J. 1986. Posição estratigráfica da Formação Seridó no contexto estratigráfico regional (RN-PB). Atas $12^{\circ}$ Simpósio de Geologia do Nordeste: 270-281.

Archanjo, C.J. and Bouchez, J.L., 1991. Le Seridó, une chaîne transpressive dextre au Proterozoique Superieur du Nord-Est du Brésil. Bull. Géol. Soc. France, 168: 509-520.

Archanjo, C.J., Legrand, J.M. 1997. Pre-brasiliano orogenic evolution in the Serido belt, NE Brazil: conflicting geochronological and structural data. Revista Brasileira de Geociencias, 27: 309-310.

Archanjo, C.J., Trindade, R.I.F., Bouchez, J.L., Ernesto, M. 2002. Granite fabrics and regional-scale strain partitioning in the Seridó belt (Borborema Province, NE Brazil). Tectonics, 21(1).

Archanjo, C.J., Launeau, P., Hollanda, M.H.B.M., Macedo, J.W.P., Liu, D. 2009. Scaterring of magnetic fabrics in the epizonal Cambrian alkaline granite of Meruoca (Ceará State, northeast Brazil). International Journal of Earth Sciences, 98: 1793-1807.

Arthaud, M.H., Caby, R., Fuck, R.A., Dantas, E.L., Parente, C.V. 2008. Geology of the northern Borborema Province, NE Brazil and its correlation with Nigeria, NW Africa. From: Pankhurst, R.J., Trouw, R.A.J., Brito Neves, B.B. \& De Wit, M.J. (eds) West Gondwama: PremCenozoic Correlations Across the South Atlantic Region. Geological Society, London, Special Publications, 294: 49-67.

Attoh, K. and Nude, P.M. 2008. Tectonic significance of carbonatite and ultrahigh-pressure rocks in the Pan-African Dahomeyide suture zone, southeastern Ghana. From: Ennih, N. \& Liegeois, J.P. (eds) The boundaries of the West African Craton. Geological Society, London, Special Publications, 297: 217-231.

Attoh, K., Corfu, F., Nude, P.M. 2007. U-Pb zircon age of deformed carbonatite and alkaline rocks in the Pan-African Dahomeyide suture zone, West Africa. Precambrian Research, 155: 251-260.

Baumgartner, R., Romer, R.L., Moritz, R., Sallet, R., Chiaradia, M. 2006. Columbite-tantalite-bearing granitic pegmatites from the Seridó Belt, northeastern Brazil: genetic constraints from U-Pb dating and $\mathrm{Pb}$ isotopes. Canadian Mineralogist, 44:69-86.

Bautista, J.M.R., Hollanda, M.H.B.M., Archanjo, C.J. 2011. Provenance signature of metasedimentary rocks from Seridó and Lavras da Mangabeira Tectonic Domain (Borborema Province, NE Brazil). Abstract Gondwana 14, Búzios, p. 116.

Bertrand, J.M., Jardim de Sá, E.F. 1990. Where are the Eburnian-Transamazonian belts? Canadian Journal of Earth Sciences, 27: 1382-1393.

Black, L.P.; Kamo, S.L.; Allen, C.M.; Aleinikoff, J.N.; Davis, D.W.; Korsch, R.J.; Foudolis, C. 2003. TEMORA 1: a new zircon standard for Phanerozoic U-Pb geochronology. Chemical Geology, 200: 155-170.

Borradaile, G.J., Werner, T. 1994. Magnetic anisotropy of some phyllosilicates Tectonophysics, 235: 223248.

Bouchez, J.L. 1997. Granite is never isotropic: an introduction to AMS studies of granitic rocks. In: Bouchez J.L., Hutton D.H.W., Stephens W.E. (eds). Granite: from segregation of melt to emplacement fabrics. Kluwer, Dordrecht, pp 95-112

Brito Neves, B.B. 1975. Regionalização geotectônica do Precambriano nordestino. Tese de Doutorado, Universidade de Săo Paulo, $198 \mathrm{pp}$.

Brito Neves, B.B. 1983. O mapa geológico do Nordeste oriental do Brasil, escala 1:1.000.000. Tese de Livre-Docência, Universidade de São Paulo, $177 \mathrm{pp}$.

Brito Neves, B.B., Santos, E.J., Van Schmus, W.R., 2000. Tectonic History of the Borborema Province, Northeast Brazil. In: Cordani, U.G., Milani, E. J., Thomaz Filho, A. Campos, D.A. (Eds.). Tectonic Evolution of South America, 31st International Geological Congress: 151-182.

Brito Neves, B.B. 2011. The Paleoproterozoic in the South-American continent: diversity in the geologic time. (SAMES Special Volume, submitted).

Brugger, J., Maas, R., Lahaye, Y., McRae, C., Ghaderi, M., Costa, S., Lambert, D., Bateman, R., Prince, $\mathrm{K}$. 2002. Origins of $\mathrm{Nd}-\mathrm{Sr}-\mathrm{Pb}$ isotopic variations in single scheelite grains from Archaean gold depositis, Western Australia. Chemical Geology, 182(2-4): 203-225.

Caby, R. 1989. Precambrian terranes of Benin Nigeria and Northeast Brazil and the Late Proterozoic South Atlantic fit. Geological Society of America Special Paper, 230: 145-158. 
Caby, R., Sial, A.N., Arthaud, M.H., Vauchez, A. 1990. Crustal evolution and the Brasiliano orogeny in Northeast Brazil. In: The West African orogens and Circum Atlantic correlatives (ed.). R.D. Dallmeyer and J.P. Lecorché. Springer Verlag: 373-397.

Caby, R., Sial, A.N., Arthaud, M.H., Vauchez, A. 1991. Crustal evolution and Brasiliano orogeny in Northeast Brazil. In: Dallmeyer, R.D., Lécorché, J.P. (eds). The West African orogens and circumatlantic correlatives. Springer-Verlag: 373-397.

Caby, R., Arthaud, M.H., Archanjo, C.J. 1995. Lithostratigraphy and petrostructural characterization of supracrustal units in the Brasiliano belt of northeast Brazil: geodynamic implications. Journal of South American Earth Sciences, 8: 235-246.

Caby, R. and Boessé, J.M. 2001. Pan-African nappe system in soutwest Nigeria: the Ife-flesha schist belt. Journal of African Earth Sciences, 33: 211-225.

Caby, R., Buscail, F., Dembélé, D., Diakité, S., Sacko, S., Bal, M. 2008. Neoproterozoic garnetglaucophanites and eclogites: new insights for subduction metamorphism of the Gourma fold and thrust belt (eastern Mali). From: Ennih, N. \& Liegeois, J.P. (eds) The boundaries of the West African Craton. Geological Society, London, Special Publications, 297: 203-216.

Cavalcante, J.C. 1999. Limites e evolução geodinâmica do Sistema Jaguaribeano, Província Borborema, Nordeste do Brasil, CE. Dissertação de Mestrado, Universidade Federal do Rio Grande do Norte, $125 \mathrm{pp}$.

Corsini, M., Vauchez, A., Archanjo, C.J., Jardim de Sá, E.F. 1991. Strain transfer at continental scale from a transcurrent shear zone to a transpressional fold belt: the Patos-Seridó system, northeastern Brazil. Geology, 19(6): 545-572.

Crandall, R. 1910. Geografia, geologia, suprimento d'água, transporte e açudagem nos estados orientais do Nordeste do Brasil, Ceará, Rio Grande do Norte, Paraíba. Boletim IFOCS, Publicação 4, Série I: $137 \mathrm{pp}$.

Dada, S.S. 2008. Proterozoic evolution of the NigeriamBorborema province. From: Pankhurst, R.J., Trouw, R.A.J., Brito Neves, B.B. \& De Wit, M.J. (eds) West Gondwama: Pre-Cenozoic Correlations Across the South Atlantic Region. Geological Society, London, Special Publications, 294: 121-136.

Dantas, E.L. 1992. Evolução tectono-magmática do maciço polidiapírico São Vicente/Florânia - RN. Dissertação de Mestrado, UNESP: $272 \mathrm{pp}$.

Dantas, E.L. 1997. Geocronologia U/Pb e Sm/Nd de terrenos arqueanos e paleoproterozoicos do Maciço Caldas Brandão, NE do Brasil. Tese de Doutorado, Universidade Estadual Paulista, 208 pp.

Dantas, E.L., Hackspacher, P.C., Van Schmus, W.R., Brito Neves, B.B. 1998. Archean accretion in the São José do Campestre Massif, Borborema Province, Northeast Brazil. Revista Brasileira de Geociências, 28(2): 221-228.

Dantas, E.L., Negrão, M.M., Buhn, B. 2008. 2.3 Ga continental crust generation in the Rio Grande do Norte terrane, NE Brazil. Abstracts VI South American Symposium on Isotope Geology, San Carlos de Bariloche, Argentina (CD-ROM, 4p), p. 40.

Dantas, E.L., Van Schmus, W.R., Hackspacher, P.C., Fetter, A., Brito Neves, B.B., Cordani, U.G., Nutman, A.P., Williams, I. 2004. The 3.4-3.5 Ga São José do Campestre massif, NE Brazil: remnants of the oldest crust in South America. Precambrian Research, 130: 113-137.

De Paolo, D.J. 1981. Neodymium isotopes in the Colorado Front Range and implications for crust formation and mantle evolution in the Proterozoic. Nature, 291: 193-197.

DePaolo, D.J., Linn, A.M., Schubert, G. 1991. The continental crustal age distribution: methods of determining mantle separation ages from $\mathrm{Sm}-\mathrm{Nd}$ isotopic data and application to the Southwestern U.S. Journal of Geophysics Research, 96: 2071-2088.

De Witt, M., Stankiewicz, J., Reeves, C. 2008. Restoring Pan-African-Brasiliano connections: more Gondwana controll, less Tran-Atlantic corruption. Geological Society, London. Special Publication, 294: 399-412.

Dunlop, D.J. 1972. Magnetic mineralogy of unheated and heated red sediments by coercivity spectrum analysis. Geophys J. R. Astron. Soc., 27: 37-55.

Ebert, H. 1969. Geologia do Alto Seridó. SUDENE, Departamento de Recursos Naturais, Divisão de Geologia, Série Geologia Regional, 11: 96 pp.

Ebert, H. 1970. The precambrian geology of the Borborema belt. State of Paraíba and Rio Grande do Norte, Northeast Brazil. Geologische Rundschau, 59(3): 1299-1326.

Ferreira, J.A.M., Albuquerque, J.P.T. 1969. Sinopse da geologia da Folha Seridó. SUDENE, Departamento de Recursos Naturais, Divisão de Geologia, Série Geologia Regional, 18: $47 \mathrm{pp}$.

Fetter, A.H. 1999. U/Pb and $\mathrm{Sm} / \mathrm{Nd}$ geochronological constraints on the crustal framework and geologic history of Ceara State, NW Borborema Province, NE Brazil: implications for the assembly of Gondwana. PhD Thesis, Kansas University, $164 \mathrm{pp}$.

Fetter, A.H., Santos, T.J.S., Van Schmus, W.R., Hackspacher, P.C., Brito Neves, B.B., Arthaud, M.H., Nogueira Neto, J.A., Wernick, E. 2000. U.Pb and Sm-Nd geochronological constraints on the crustal evolution and basement architecture of Ceará State, NW Borborema, NE Brazil: implications for the 
existence of the Paleoproterozoic supercontinent Atlantica. Revista Brasileira de Geociências, 30: $102-106$.

Fetter, A.H., Saraiva dos Santos, T.J., Van Schmus, W.R., Hackspacher, P.C., Brito Neves, B.B., Arthaud, M.H., Nogueira Neto, J.A., Wernick, E., 2003. Evidence for Neoproterozoic Continental Arc Magmatism in the Santa Quitéria batholith of Ceará State, NW Borborema Province, NE Brazil: implications for the Assembly of West Gondwana. Gondwana Research, 6: 265-273.

Frei, R.; Kamber, B.S. 1995. Single mineral Pb-Pb dating. Earth Planetary Science Letters, 129: 261-268.

Frei, R.; Nägler, T.F.; Schönberg, R.; Kramers, J.D. 1998. Re-Os, Sm-Nd, U-Pb, and stepwise lead leaching isotope systematics in shear-zone hosted gold mineralization: genetic tracing and age constraints of crustal hydrothermal activity. Geochimica and Cosmochimica Acta, 62(11): 1925-1936.

Guimarães, I.P., Araújo, D.B., Silva Filho, A.F., Silva, F.M.V., Armstrong, R. 2009. Idades U-Pb em zircão por SHRIMP do magmatismo máfico e félsico do Complexo Serrinha-Pedro Velho, Província Borborema, NE Brazil. Atas $23^{\circ}$ Simpósio de Geologia do Nordeste, CD-ROM.

Hackspacher, P.C., Van Schmus, W.R., Dantas, E.L. 1990. Um embasamento transamazônico na Província Borborema. Anais $36^{\circ}$ Congresso Brasileiro de Geologia, 6: 2683-2696.

Hamilton, P.J., O'Nions, R.K., Bridgwater, D., Nutman, A. 1983. Sm-Nd studies of Archean metasediments and metavolcanics from West Greenland and their implications for the Earth's early history. Earth Planetary Science Letters, 62: 263-272.

Hollanda, M.H.B.M., Pimentel, M.M., Jardim de Sá, E.F. 2003. Paleoproterozoic subduction-related metasomatic signatures in the lithospheric mantle beneath NE Brazil: inferences from trace element and $\mathrm{Sr}-\mathrm{Nd}-\mathrm{Pb}$ isotopic compositions of Neoproterozoic high-K igneous rocks. Journal of South American Earth Sciences: 15: 885-900.

Hollanda, M.H.B.M., Archanjo, C.J., Souza, L.C., Armstrong, R., Vasconcelos, P.M. 2010. Cambrian mafic to felsic magmatism and its connections with transcurrent shear zones of the Borborema Province (NE Brazil): implications for the late assembl;y of the West Gondwana. Precambrian Research, 178: 1-14.

Hollanda, M.H.B.M., Archanjo, C.J., Souza, L.C., Liu, D., Armstrong, R. 2011. Long-lived Paleoproterozoic granitic magmatism in the Seridó-Jaguaribe domain, Borborema Province - NE Brazil. Journal of South American Earth Sciences, 32: 287-300.

Jackson, M. 1991. Anisotropy of magnetic remanence: a brief review of mineralogical sources, physical origins and geological applications, and comparison with susceptibility anisotropy. Pageoph., 136: 128.

Jardim de Sá, E.F. 1982. Evolução tectônica da região do Seridó: síntese preliminar, problemas e implicaçōes. Boletim do Departamento de Geologia, CCE-UFRN, 5: 1-17.

Jardim de Sá, E.F. 1984. Geologia da região do Seridó: reavaliação de dados. Atas $11^{\circ}$ Simpósio Geologia do Nordeste: 278-296.

Jardim de Sá, E.F. 1994. A Faixa Seridó (Província Borborema, NE do Brasil) e o seu significado geodinâmico na cadeia Brasiliana/Pan-Africana. Tese de Doutorado, Universidade de Brasília, 803 $\mathrm{pp}$.

Jardim de Sá, E.F., Salim, J. 1980. Reavaliação dos conceitos estratigráficos na região do Seridó (RN. PB). Mineral. Metalogenia, 80: 16-28.

Jardim de Sá, E.F., Legrand, J.M., McReath, I. 1981. "Estratigrafia" preliminar de rochas granitóides na região do Seridó (RN-PB), com base em critérios estruturais. Revista Brasileira de Geociências, 11: 50-57.

Jardim de Sá, E.F., Legrand, J.M., Galindo, A.C., Sá, J.M., Hackspacher, P. 1986. Granitogênese brasiliana no Seridó: o maciço de Acari (RN). Revista Brasileira de Geociências, 16: 95-105

Jardim de Sá, E.F.; Macedo, M.H.F., Legrand, J.M., McReath, I., Galindo, A.C., Sá, J.M. 1987. Proterozoic granitoids in a polyciclic setting: the Seridó region, NE Brazil. $1^{\circ}$ International Symposium on Granites and Associated Mineralization, Abstracts: 103-110.

Jardim de Sá, E.F., Fuck, R.A., Macedo, M.H.F., Peucat, J.J., Kawashita, K., Souza, Z.S., Bertrand, J.M. 1995. Pre-brasiliano orogenic evolution in the Seridó belt, NE Brazil: conflicting geochronological and structural data. Revista Brasileira de Geociências, 25: 79-87.

Kempe, U., Belyatsky, B.V., Krymsky, R.S., Kremenetsky, A.A., Ivanov, P.A. 2001. Sm-Nd and Sr isotope systematics of scheelite from the giant Au-W deposit Muruntau Uzbekistan: implications for the age and sources of Au minerallization. Mineralium Deposita, 36: 379-392.

Kent, A.J.R., Campbell, I.H., McCulloch, M.T. 1995. Sm-Nd systematics of hydrothermal scheelite from the Mount Charlotte Mine, Kalgoorlie, Western Australi: an isotopic link between gold mineralization and komatites. Economic Geology, 90(8): 2329-2335.

Jardim de Sá, E.F., Macedo, M.H.F., Falcão Torres, H.H.H., Kawashita, K. 1988. Geochronology of metaplutonics and the evolution of supracrustal belts in the Borborema Province, NE Brazil. Anais VII Congresso Latino-Americano de Geologia, vol. 1: 49-62. 
Legrand, J.M., Liégeois, J.P., Deustch, S. 1991. Datação U/Pb e $\mathrm{Rb} / \mathrm{Sr}$ das rochas precambrianas da região de Caicó. Reavaliação da definição de um embasamento arqueano. Atas $14^{\circ}$ Simpósio de Geologia do Nordeste: 276-279.

Legrand, J.M., Deutsch, S., Souza, L.C., 1991. Datação U-Pb e granitogênese do maciço de Acari (RN). Atas $14^{\circ}$ Simpósio de Gelogia do Nordeste: 172-174.

Leterrier, J., Jardim de Sá, E.F., Bertrand, J.M., Pin, C., 1994. Ages U-Pb sur zircon de granitoides "brasilianos" de la ceinture du Seridó (Province Borborema, NE Brésil). C.R. Acad. Sci. Paris, t. 318, série II, p. 1505-1511.

Lima, E.A.M. et al. 1980 Projeto Scheelita do Seridó. DNPM/CPRM, Relatório Final e Mapas.

Lima, E.S. 1987. Evolução termo-barométrica das rochas metapelíticas da egião do Seridó, Nordeste Brasileiro. Revista Brasileira de Geociências, 17: 315-323.

Lima, E.S., Pessoa, R.J.R., Accioly, A.C.A. 1989. O metamorfismo de contato causado pelo gabronorito de Totoró, Currais Novos, Rio Grande do Norte, Nordeste Brasileiro. Revista Brasileira de Geociências. 19: 323-329.

Liu, Y., Deng, J., Li, C.F., Shi, G.H., Zheng, A. 2007. REE composition in scheelite and scheelite Sm-Nd dating for the Xuebaoding W-Sn-Be deposit in Sichuan. Chin. Sci. Bull., 52(18): 2543-2550.

Ludwig, K.R. 2000. SQUID 1.00. A user manual. Berkeley Geochronology Center, Spec. Publ., vol. 2. Berkeley, CA, $17 \mathrm{pp}$.

Ludwig, K.R. 2003. Isoplot 3.00: a geochronological toolkit for Microsoft Excel ${ }^{\circledast}$ (revised version). Berkeley Geochronological Center, Spec. Publ. vol. 4, Berkeley, CA, 70 pp.

Lugmair, G.W; Marti, K. 1978. Lunar initial $143 \mathrm{Nd} / 144 \mathrm{Nd}$ : differential evolution of the lunar crust and mantle. Earth Planetary Sci. Lett., 39: 349-357.

Macedo, M.H.F., Jardim de Sá, E.F., Sá, J.M. 1984. Datações Rb.Sr em ortognaisses e a idade do Grupo Seridó. Atas $11^{\circ}$ Simpósio de Geologia do Nordeste: 253-262.

Macedo, M.H.F., Jardim de Sá, E.F., Peucat, J.J., Souza, Z.S., Martin, H. 1991. Avaliação dos dados geocronológicos do Complexo Caicó (RN) e suas implicações tectônicas. Atas $14^{\circ}$ Simpósio de Geologia do Nordeste: 256-259.

Mezger, K., Krogstad, E.J. 1997: Interpretation of discordant U-Pb zircon ages: an evaluation. Journal of Metamorphic Geology, 15: 127-140.

Nascimento, M.A.L., Antunes, A.F., Galindo, A.C., Jardim de Sá, E.F., Souza, Z.S. 2000. Geochemical signature of the Brasiliano-age plutonism in the Seridó belt, Northeastern Borborema Province (NE Brazil). Revista Brasileira de Geociências, 30: 161-164.

Omitogun, A.A., Caby, R., Debat, P. 1991. Le métamorphism pan-african de la partie centrale de la zone mobile du Nigéria (Ceinture schisteuse d'Igarra s.I.). C. R. Acad. Sci. Paris, t. 313, Série II, p. 14171423.

Ozdemir, O., Dunlop, D.J., Moskowitz, B.M. 1993. The effect of ixidation on the Verwey transition in magnetite. Geophysical Research Letters, 20(16): 1671-1674.

Parente, C.V., Ronchi, L.H., Sial, A.N., Guillou, J.G., Arthaud, M.H., Fuzikawa, K., Veríssimo, C.U.V. 2004. Geology and geochemistry of paleoproterozoic magnesite deposits $(\sim 1.8 \mathrm{Ga})$, state of Ceará, Northeastern Brazil. Carbonates and Evaporites, 19: 28-50.

Pin, C, Poidevin, J.L. 1987. U-Pb zircon evidence for a Pan-African granulite facies metamorphism in the Central African Republic. A new interpretation of the high-grade series of the northern border of the Congo craton. Precambrian Research, 36: 303-312.

Rahaman, M.A. 1988. Recent advances in the study of the basement complex of Nigeria. In: Oluyide, P.O. et al. (eds), Precambrian Geology of Nigeria. Geological Survey of Nigeria, 11-43.

Ries, A.C.; Shackleton, R.M. 1977. Preliminary note on structural sequences and magnitude and orientation of finite strains in the Precambrian of Northeast Brazil. Atas $8^{\circ}$ Simpósio de Geologia do Nordeste: $397-400$.

Rochette, P., 1987. Magnetic susceptibility of the rock matrix related to magnetic fabric studies. Journal of Structural Geology, 9(8): 1015-1020.

Sá, J.M. 1991. Évolution geodynamique de la ceinture proterozoicque d'Orós, Nord-est Brésil. Faculté de Sciences de l'Université de Nancy, Nancy. Tese de Doutorado, $177 \mathrm{pp}$.

Sá, J.M., McReath, I, Leterrier, J. 1995. Petrology, geochemistry and geodynamic setting of Proterozoic igneous suites of the Orós fold belt (Borborema Province, Northeast Brazil). Journal of South American Earth Sciences, 8(3/4): 299-314.

Salim, J. 1993. Geologie, petrologie et geochimie des skarns a scheelite de la mine Brejuí, Currais Novos, region du Seridó, NE du Bresil. These de Doctorat, Universitè Catholique de Louvain, 272 pp.

Santos, E.J. 1973. Província Scheelitifera do Nordeste. $27^{\circ}$ Congresso Brasileiro de Geologia: 31-46.

Santos, E.J., Brito Neves, B.B. 1984. Província Borborema. In: Almeida, F.F.M., Hasui, Y. (eds). O PréCambriano do Brasil. Edgard Blucher: 123-186. 
Santos, E.F., Coutinho, M.G.N., Costa, M.P.A., Ramalho, R. 1984. A região de Dobramentos Nordeste e a Bacia do Parnaiba, incluindo o Cráton São Luis e as bacias marginais. In: Schobbenhaus, C., Campos, D.A., Derze, G.R., Asmus, H.E. (eds). Geologia do Brasil, texto explicativo do mapa geológico do Brasil e da area oceânica adjacente, incluindo depósitos minerais. Departamento Nacional de Produção Mineral: 131-189.

Santos, E.J., Brito Neves, B.B., Van Schmus, W.R., Oliveira, R.G., Medeiros, V.C., 2000. An overall view on the displaced terrane arrangement of the Borborema Province, NE-Brazil. Proceedings 31st International Geological Congress (in CD-Rom).

Santos, T.J.S., Fetter, A.H., Nogueira Neto, J.A. 2008. Comparisons between the northwestern Borborema province, NE Brazil, and the southwestern Pharusian Dahomey belt, SW central Africa. In: Pankhurst, R.J., Trouw, R.A.J., Brito Neves, B.B., De Witt, M.J. (eds), West Gondwana: PreCenozoic correlations across the Atlantic region. Geological Society Special Publication, 294: 101119.

Santos, T.J.S., Fetter, A.H., Van Schmus, W.R., Hackspacher, P.C. 2009. Evidence for 2.35 to 2.30 Ga juvenile crustal growth in the northwest Borborema Province, NE Brazil. Geological Society, London, Special Publications, 323: 271-281.

Silva, L.C., McNaughton, N.J., Vasconcelos, A.M., Gomes, J.R.C., Fletcher, I.R. 1997. U/Pb SHRIMP ages in Southern state of Ceará, Borborema Province, NE Brazil: Archean TTG accretion and Proterozoic crustal reworking. Abstract International Symposium on Granites and Associated Mineralizations: $280-281$.

Souza, Z.S. 1991. Petrogénèse des metagranitoides du Complexe de Caicó, Province Borborema (Etat du Rio Grande do Norte, Brésil). Mém. DESS, Institute de Géologie, Université de Rennes I: 87 pp.

Souza, Z.S., Martin, H., Macedo, M.H.F., Peucat, J.J., Jardim de Sá, E.F. 1993. Un segment de croûte continentale juvénile d'áge protérozoique inférieur: le Complexe de Caicó (Rio Grande do Norte, NEBrésil). Comptes Rendus de l'Académie des Sciences, Paris III, 316: 201-208.

Souza, L.C., 1996. Zoneaogaphie metamorphique, chimie des mineraux, petrochimie, geochronologie ${ }^{40} \mathrm{Ar} /{ }^{39} \mathrm{Ar}$ et histoire P-T-t des micaschistes engloband le massif gabbro-granitique d'Acari (Brasiliano), Ceinture mobile du Seridó (NE du Brésil). These de Doctorat, Laboratoire de Géologie et Mineralogie, Université Catholique de Louvain, Belgique, 345p.

Souza, Z.S., Montel, J.M., Gioia, S.M.L.C., Hollanda, M.H.B.M., Nascimento, M.A.L., Jardim de Sá, E.F., Amaro, V.E., Pimental, M., Lardeaux, J.M., Veschambre, M. 2006. Eletron micropobe dating of monazite from high-T shear zones in the São José de Campreste Massif, NE Brazil. Gondwana Research, 9: 441-455.

Souza, Z.S., Martin, H., Peucat, J.J., Jardim de Sá, E.F., Macedo, M.H.F. 2008. Calc-alkaline magmatism at the Archean-Proterozoic transition: the Caicó Complex basement (NE Brazil). Journal of Petrology, 48(11): 2149-2185.

Stacey, J.S. and Kramers, J.D. 1975. Approximation of terrestrial lead isotope evolution by a two stage model. Earth and Planetary Science Letters, 26: 207-221.

Tarling, D.H., Hrouda, F. 1993. The magnetic anisotropy of rocks. Chapman \& Hall, $217 \mathrm{pp}$.

Trindade, R.I.F. 1999. Magnetismo de corpos graníticos e a evolução tectônica brasiliana da porção ocidental da Faixa Seridó (NE do Brasil). Tese de Doutorado, Universidade de São Paulo, 103 pp.

Trompette, R. 1997. Neoproterozoic ( $600 \mathrm{Ma}$ ) aggregation of Western Gondwana: a tentative scenario. Precambrian Research, 82: 101-112.

Van Schmus, W.R., Brito Neves, B.B., Hackspacher, P.C., Babinski, M., 1995. U-Pb and Sm-Nd geochronological studies of the Eastern Borborema Province, Northeast Brazil: initial conclusions. Journal of South American Earth Sciences, 8: 267-288.

Van Scmus, W.R., Brito Neves, B.B., Williams, I., Hackspacher, P.C., Fetter, A.H., Dantas, E.L., Babisnki, M. 2003. The Serido Group of NE Brazil, a late Neoproterozoic pre- to syn-collisional basin in West Gondwana: insights from SHRIMP U-Pb detrital zircon ages and $\mathrm{Sm}-\mathrm{Nd}$ crustal residence (TDM) ages. Precambrian Research, 127: 287-327.

Van Schmus, W.R., Oliveira, E.P., Silva Filho, A.F., Toteu, S.F., Penaye, J., Guimarães, I.P. 2008. Proterozoic links between the Borborema Province, NE Brazil, and the Central African Fold Belt. From: Pankhurst, R.J., Trouw, R.A.J., Brito Neves, B.B. \& De Wit, M.J. (eds) West Gondwama: PreCenozoic Correlations Across the South Atlantic Region. Geological Society, London, Special Publications, 294: 69-99.

Vauchez, A., Neves, S., Caby, R., Corsini, M., Egydio-Silva, M., Arthaud, M., Amaro, V.E. 1995. The Borborema Shear Zone System, NE Brazil. Journal of South American Earth Sciences, 8: 247-266.

Zeh, A., Holness, M.B. 2003. The effect of reaction overstep on the garnet microstructures in metapelitic rocks of the llesha schist belt, SW Nigeria. Journal of Petrology, 44: 967-994. 
